\title{
LAIDOJIMAS PILKAPIUOSE KRIKŠČIONIŠKOJOJE LIETUVOJE
}

\author{
LAURYNAS KURILA
}

Lietuvos istorijos institutas, Archeologijos skyrius, Kražių g. 5, 01008 Vilnius, el. paštas: laurynas.kurila@istorija.lt

Lietuvos vèlyvuju viduramžiu - ankstyvuju naujuju laiku (XIV a. pabaigos - XVIII a.) senkapiu kontekste išsiskiria kapai, ̨̣kasti i geležies amžiaus pilkapius. Iki šiol Lietuvoje rasta mažiausiai 400 vellyvu kapu 26-iuose pilkapynuose, dar bent apie 25-is pilkapynus turima fragmentiškos informacijos. Ankstyviausi kapai senuose pilkapiuose datuotini XIV a. pabaiga-XVa., tačiau masine tokia laidosena tapo XVI-XVII a. Pagrindinis šio papročio sklaidos arealas yra Žemaitija ir Šiaurès Lietuva. Iranga, orientacija, ¿̨kapių komplektais šie kapai niekuo neišsiskiria iš istoriniu laiku senkapių.

Kapinynu sugrižima i senuosius pilkapynus reikia sieti su Lietuvos christianizacija. Viena vertus, iki XVI a. Lietuvos provincijos gyventoju evangelizacija nebuvo intensyvi, todèl neįsitvirtino laidojimas bažnyčiu šventoriuose ir krikščioniškos apeigos. Kita vertus, Reformacijos ir ypač Kontrreformacijos laikotarpyje sutankintas bažnyčiu tinklas, išaugęs Bažnyčios spaudimas laikytis krikščionišku laidojimo apeigu bei lupikiški mokesčiai už jas, krikščionybès autoriteto stoka galejo skatinti gyventoju priešiškumą. Jiems teko ieškoti nuošalesniu vietų kapinynams, ir jas kai kurios bendruomenès rado senuose pagoniškuose pilkapynuose.

Reikšminiai žodžiai: pilkapiai, pakartotinis laidojimas, viduramžiai, ankstyvieji naujieji laikai, christianizacija.

Burials dug into Roman period - Viking age barrows can be distinguished in the context of the cemeteries from Lithuania's Late Medieval - Early Modern period (late $14^{\text {th }}-18^{\text {th }}$ centuries). So far, at least 400 late burials have been found in 26 Lithuanian barrow cemeteries while only fragmentary information is available about another 25 such barrow cemeteries. The earliest historical period burials in old barrows should be dated to the late $14^{\text {th }}-15^{\text {th }}$ centuries, but this burial practice began to occur on a mass scale in the $16^{\text {th }}-17^{\text {th }}$ centuries. The main incidence range of this custom is Samogitia and North Lithuania. In respect to their construction, orientation, and grave good assemblages, these burials do not differ in any way from the context of the historical period cemeteries.

The return of burials to old barrow cemeteries should be connected with the Christianisation of Lithuania. On the one hand, up until the $16^{\text {th }}$ century the evangelisation of Lithuania's rural population was not intensive and therefore burial in a churchyard and Christian rites were not well established. On the other hand, the compressed church network during the Reformation and especially the CounterReformation, the increased pressure from the Church to observe Christian burial rites and pay the exorbitant fees for them, and the lack of Christianity's authority could have provoked the population's hostility, forcing people to look for more remote locations for cemeteries, locations some communities found in old pagan barrow cemeteries.

Keywords: barrows, cemetery reuse, Middle ages, Early modern times, christianization.

\section{IVADAS}

Laidojimo papročiai, skirtingai nei daugelis bazinių poreikių nulemtų žmogaus veiklos modelių, dažniausiai yra vien kultūros, mirusiųjų pasaulio vaizdinių ir socialinių normų išraiška. Žinoma, jiems itakos turi ir gamtinès sąlygos, o tam tikros aplinkybės, pvz., karas ar epidemija, gali tapti laidojimo būdo pokyčių priežastimis. Tačiau dauguma laidosenos bruožų yra visuomenès pasirinkimo, prisitaikymo 
prie socialinès ir kultūrinės aplinkos, o ne išorinių veiksnių rezultatas. Todèl laidojimo papročių raida neretai būna dinamiška, lemiama tiek kultūrinių kontaktų, tiek vidinių kultūrinių, religinių ar socialinių naujovių. Nukrypimas nuo tradicijos gali likti vienkartinis, tapti priemone pabrèžti išskirtinumą arba pats ilgainiui tapti tradicija. Nors neatmestinas atsitiktinumas ar tiesiog „žmogiškasis faktorius“, tokie nukrypimai nuo normos paprastai turi gilesni pagrindą - savotiškas nukrypimo nuo taisyklių taisykles, aktualias konkrečioje kultūrinejje erdvejje. Dèl to, o galbūt ir dèl temos egzotiškumo „neịprasti“ kapai susilaukia nemažai archeologų dèmesio (pvz., Murphy 2008; Aspöck 2009; Reynolds 2009; Gardeła, Kajkowski 2013; Kaznakov 2013; Milella ir kt. 2015). Archeologų vaizduotę ypač audrina ịvairūs pavieniai išskirtiniai kapai (individai, palaidoti pastatuose, už kapinių ribų, be galvų, kniūbsti, persmeigti kuolais, užversti akmenimis ar pan.). Kita vertus, neịprastais galima laikyti ne tik kapus, kurie paprastai įvardijami kaip „vampyrų“, nekrikštų, vergų, paaukotųjų, savižudžių, smurto ar bausmių aukų palaidojimais, o dažniausiai juntama negatyvi „kitoniškumo“ konotacija nebūtinai visuomet yra pagrịsta. Kažkada, pvz., Lietuvoje buvo neipprasti ir pirmasis pilkapis, pirmasis degintinis kapas ar pirmasis kapas bažnyčios šventoriuje. Kitoniška gali būti ne tik tam tikra kapo konstrukcija ar neiprastas elgesys su palaikais, bet ir kapo vieta - padètis gamtiniame ir kultūriniame kraštovaizdyje. Kiekviena visuomenė šiuo požiūriu turi tam tikras normas, o nutolimas nuo jų (ar kitų normų paieškos) vertas ne mažiau dèmesio nei kai kurie pavieniai intriguojantys atvejai.

Lietuviškojoje Lietuvos Didžiosios Kunigaikštystès (toliau - LDK) dalyje nuo XIV-XV a. įsivyraujant krikščionybei, laidojimo papročiai pamažu kito. Absoliuti dauguma miestų, miestelių ir kaimo gyventojų (išskyrus dvasininkus ir didikus, laidotus bažnyčių šventoriuose ar kriptose) amžinojo poilsio atgulè kapinynuose, archeologinèje literatūroje dar vadinamuose senkapiais. Krikščionybè, gentinių ir materialinès kultūros skirtumų nykimas lèmè laidojimo papročių supanašèjimą, atvedusị iki pat dabartinio kapinių standarto. I pavienius „netradicinius“, iš visumos išsiskiriančius kapus buvo atkreiptas archeologų dèmesys (Vèlius 2010; Simniškytė 2018). Vis dèlto pažymètina, kad jo nepelnytai pristigo kapams, kurių kitoniškumas slypi epochai nebūdingoje laidojimo vietoje, konkrečiai - grịžime ì senuosius pilkapynus. Išskyrus trumpus pastebejjimus (Svetikas 2003, p. 19; Simniškytė 2013, p. 173-174), viduramžių ir naujųjų laikų kapai geležies amžiaus pilkapiuose pateko daugiausia i pastarojo laikotarpio tyrinètojų akiratị, tad nenuostabu, kad dèmesys jiems apsiribojo apibūdinimu tyrimų publikacijose (pvz., Michelbertas 2004, p. 127-138; 2006, p. 108-127; 2011, p. 209-219), o kartais mokslininkų požiūris ị juos atrodo lyg i geležies amžiaus medžiagos „balastą“. Istorinių laikų tyrèjai šių kapų neišskiria iš senkapių medžiagos visumos. Taigi niekur šio laikotarpio kapai pilkapiuose nenagrinèti kaip fenomenas, jų nepamėginta išskirti iš bendro senkapių konteksto, ịvertinti per kultūrinę ir religinę prizmę ar bent suskaičiuoti.

Pakartotinis pilkapių ar kitų laidojimo vietų (ypač tokių monumentalių, kaip neolito ir bronzos amžiaus pilkapiai ar megalitai) naudojimas yra dažna praeities laidosenos praktika Europoje, paprastai siejama su siekiais įtvirtinti socialinio statuso skirtumus, kolektyvine atmintimi bei protèvių kultais, kurie tampa ypač aktualūs migracijų, socialinès kaitos laikotarpiais (Holtorf 1998; Semple 1998; Williams 1998; 2006, p. 181-185; Pedersen 2006; Wickholm 2008; Crewe 2010, p. 43-57; Halsall 2010, p. 249-257; Hejhal, Lutovský 2012; Hutton 2011; Artelius 2013; Van Beek, De Mulder 2014; Curta 2016; Fahlander 2016). Tokios laidosenos pavyzdžių nemažai ir priešistorinio laikotarpio Lietuvoje. Tai gali būti ir kelių šimtmečių skiriami, tačiau tos pačios laidojimo pilkapiuose tradicijos jungiami kapai viename sampile, kokių dažnai pasitaiko Rytų Lietuvos pilkapynuose, 
ir kapai, ị pilkapius ịkasti jau išnykus jų pylimo tradicijai, tačiau tebegyvuojant ideologiniam jos pagrindui - pagoniškajai pasaulèžiūrai, kaip kai kuriuose toliau aptariamuose pilkapynuose.

Šiame straipsnyje dèmesys sutelkiamas ne apskritai i pakartotinio laidojimo ankstesnèse vietose fenomeną Lietuvoje - tai ne tik būtų labai išsamaus tyrimo, apimančio visą geležies amžiaus apgyvendinimo ir kultūrų kaitos dinamiką, reikalaujanti tema, bet dažnu atveju tyrimą labai apsunkintų netikslus kapų datavimas. Lietuvoje nèra kapų, ịkastų $\mathfrak{i}$ tūkstantmečiais senesnes konstrukcijas, kokių aptinkama Vakarų Europoje, Britų salose ar Skandinavijoje, bet geležies amžiuje laidojimas ankstesniuose pilkapiuose nebuvo retas, ypač Rytų Lietuvoje, kur pilkapių tradicija gyvavo beveik tūkstantmetị. Dažnu atveju nustatyti, ar kapus viename sampile skiria keleri metai, ar šimtmečiai, yra sunku. Šiaurès Lietuvoje, Roméniškojo laikotarpio pilkapių areale, nereta buvusių pilkapynų tąsa jų erdvei pavirtus jau plokštiniais kapinynais. Dažniausiai pilkapio supylimo meto ir vèlesnius kapus sieja ir panaši laidojimo tradicija, ir materialioji kultūra.

Straipsnio objektas - laidosena senuose pilkapiuose Lietuvoje krikščioniškajame laikotarpyje. Būtent toks jo apibrèžimas nulemtas ne siekio susiaurinti tyrimo apimtị iki aprépiamos viename straipsnyje. Pirma, skirtingai nuo galimai atsitiktinio pakartotinio laidojimo ankstesniuose plokštiniuose kapinynuose ar jų tąsos, čia aptariami tie atvejai, kai mirusiųjų pasaulio grąžinimas ị senąsias vietas buvo sąmoningai suvoktas, nulemtas kraštovaizdyje vizualiai išsiskiriančių pilkapių. Antra, aptariamu laikotarpiu pilkapių tradicija jau buvo bent kelis šimtmečius, Šiaurès Lietuvoje ir tūkstantmetį, nutrūkusi, baigè nykti pagonybè ir senoji pasaulèžiūra. Kitaip tariant, krikščioniškoje aplinkoje, kitaip nei pagoniškoje, šios tradicijos atnaujinimas nebuvo vien formos ir vietos pokytis. Christianizuotoje ar christianizacijos poveiki patiriančioje visuomenejje jis negalejo būti atsitiktinis.
Aptariamuoju metu LDK apèmè didžiulę teritoriją, kurioje būta didelès religijų, kultūrų ir laidojimo papročių ìvairovès. Galbūt pirmosiose ị jos sudètị patekusiose Rytų slavų kunigaikštystèse tuo metu dar tebelaidota ir pilkapiuose (Седов 1982, p. 119, 168; Зверуго 1989, р. 104-106; Звяруга 2005, p. 134). Straipsnyje krikščioniškoji LDK yra chronologinè kategorija - XIV a. pabaiga - XVIII a. (formaliai - 1387-1795 m.). Erdvès požiūriu apsiribojama dabartinès Lietuvos teritorija.

\section{KAPŲ APŽVALGA}

Sugrịžimas ị senąsias laidojimo erdves po tam tikros pertraukos, taip pat istoriniais laikais, matomas ne tik pilkapynų, bet ir daugelio plokštinių kapinynų medžiagoje, o tai, tikètina, yra nulemta ne tik ideologinių priežasčių ar atminties, bet ir konkrečios vietovès vaizdingumo ir panašiai suprantamų topografinių laidojimo vietos kriterijų. Istorinių laikų senkapio kraštovaizdis iš esmès nesiskiria nuo priešistorinio kapinyno, todèl naujo laidojimo etapo ar laidojimo tęstinumo nereikètų laikyti išskirtiniu. Kita vertus, kai kurie tyrinèti didžiuliai Lietuvos kapinynai (pvz., Marvelè, Veršvai, Ėgliškiai-Anduliai, Laiviai) rodo ilgalaikį nepertraukiamą laidojimą, ir tai gali būti daugiau taisyklè nei išimtis, tiesiog menami chronologiniai protrūkiai ir pakartotinio laidojimo fazès kitose vietose gali būti nulemti suardymų ar netolygių tyrimų.

Aiškesnị aptiktų i pilkapius įkastų LDK laikotarpio kapų skaičių nurodyti sunku. Daugelio toliau aprašomų tyrimų metu rasta ne tik kapų, bet ir visiškai suardytų palaidojimų liekanų. Dažnu atveju pilkapynai buvo tapę ištisais ankstyvųjų naujųjų laikų senkapiais, kuriuose laidota tiek sampiluose, tiek tarp jų, tiek galbūt jau tuomet sunykusių pilkapių vietose. Kadangi tiriant paprastai susitelkiama $\mathfrak{i}$ pilkapius, vidinè tokių senkapių struktūra, kapų tankumas, chronologinè raida dažniausiai lieka neaiški. 
Daugybė pilkapynų, ypač Šiaurès Lietuvoje, buvo visiškai sunaikinti arba jų išliko menki fragmentai (pvz., Raginènai, Norkūnai, Sotkalnis, Kernavè), labai tikètina, kad daugelio pilkapynų neliko nei žymès, nei jokios informacijos apie juos. Šimtmečius būtent pilkapynai, tikètina, buvo daug sparčiau niokojami nei tebenaudojamos ar dar nepamirštos istorinių laikų kapinès. Suardytų I t-mečio 1-osios pusès pilkapių liekanų kartais aptinkama tyrinèjant senkapius. Todèl realūs šių dviejų kategorijų laidojimo paminklų erdvinio persidengimo mastai yra neaiškūs.

Esama laidojimo paminklų, kuriuose su pertraukomis ar be jų laidota nuo I t-mečio iki XIII-XV a. Tačiau pastarojo laikotarpio dirbinių chronologija tebèra nepakankamai tiksli - bent tiek, kad leistų suardytų kompleksų liekanas patikimai skirstyti ị datuotinas geležies amžiaus pabaiga ar viduramžiais, taip pat šiame straipsnyje nagrinejjamo laikotarpio pradžia. Kai kur, neretai plokštinių kapų apsuptyje, aptinkama tik (spejjamų) pilkapių liekanų (pvz., Gèluva), kartais vèlyvąji laidojimo etapą rodo buvus irgi daugiausia dirbiniai iš suardytų kapų, taigi santykis tarp atskirų laidojimo etapų lieka neaiškus.

Toliau (taip pat žr. priedą) pateikiama ištirtų istorinių laikų kapų geležies amžiaus pilkapiuose apžvalga. Surinkti duomenys apie 400-us kapų iš 26-ių pilkapynų (1 pav.). Tai yra minimalus skaičius, apimantis tiktai pačius aiškiausius atvejus. Apie dar 25-iuose pilkapynuose rastus vèlyvus kapus turima daugiau ar mažiau patikimų, tačiau nepakankamų duomenų. Pilkapynai aptariami neatsižvelgiant $\mathfrak{i}$ etnokultūrinę jų supylimo laiko situaciją, kuri istoriniais laikais buvo nebeaktuali.

Daugiausia vèlyvų kapų ištirta Pajuosčio pilkapyne (Panevėžio r., Miežiškių sen.). 15-oje senojo geležies amžiaus pilkapių (kai kuriuose jų laidota ir vėlyvajame geležies amžiuje) bei perkasoje i $\mathrm{P}$ nuo pilk. XXI ištirtas 91 ankstyvųjų naujųų laikų kapas. Mirusieji laidoti ịvairaus gylio $(0,3-1,5 \mathrm{~m})$ duobėse ịvairiose sampilų vietose, beveik visi krikščionišku papročiu galvomis V kryptimi, su nedideliais nuokrypiais link ŠV ar PV, vos keli - kitomis kryptimis (pilk. III k. 6 (B) - i Daugelis kapų buvo apardyti, kai kurie - kasant duobes vèlesniems kapams. Sprendžiant iš negausių ikapių - daugiausia monetų - šis laidojimo etapas apima XVI-XVIII a., keli kapai galbūt datuotini ir XIX a. (Michelbertas 2004, p. 97-152). Iš esmès pilkapynas buvo tapęs ipprastomis kaimo kapinèmis, kuriose nuo tam tikro laiko greičiausiai laidota jau neskiriant pilkapių sampilų ir erdvių tarp jų. Išskyrus kasdienius aksesuarus, taip pat krikščioniškus atributus, nelaikytinus papildomomis ịkapėmis, bei monetas, vos keliuose kapuose aptikta dirbinių, galbūt sietinų su vėlyvąja pagonybe, pvz., pilk. IX k. 28 (B) (Michelbertas 2004, p. 130, 142). Taip pat galima atkreipti dėmesị i k. 86 (A) (perkasa III), kuriame peilis buvo ismeigtas ị žemę (Michelbertas 2004, p. 151).

Riklikų pilkapyne (Anykščių r.) ištirtuose 14-oje I t-mečio vidurio pilkapių ir viename šurfe tarp jų aptikta 80 vèlyvų kapų ir dar kelių dešimčių suardytų kapų liekanų. Nors kasinėta tik pilkapyne, minima, kad kapų liekanų būdavo aptinkama ir jo aplinkoje (Tautavičius 1969, p. 8), taigi vėlyvo senkapio teritorija buvo didesnè nei pilkapyno. Kapai buvo ịvairiose sampilų vietose ir gyliuose, daugelis ikkasti suardant ankstesnius. Beveik visi individai palaidoti galvomis $\mathfrak{i} \mathrm{V}$ ar su nedideliu nuokrypiu nuo šios krypties. Nemaža dalis palaidotųjų - vaikai. Idomi pilk. VIII k. 2 konstrukcija: jo duobès viršuje buvo sukrautas akmenų grindinèlis (Tautavičius 1969, p. 5859). İkapès negausios ir neịvairios, daugelyje kapų jų visai nebuvo.

Didesnis ankstyvųjų naujųjų laikų senkapiams būdingas ịkapių kompleksas (plačiaašmenis kirvis, peilis, dvi sagtys, piniginè ir puodas), aptiktas pilk. II k. 10 (Tautavičius 1970, p. 22). Kapai tyrèjo datuoti XVI-XVII ar XVI-XVIII a. (Tautavičius 1970, p. 54, 59), tačiau nusistovejusi krikščioniška mirusiųjų orientacija i $\mathrm{V}$ ir mažas ịkapių skaičius igalina daugumos jų chronologiją sąlygiškai vèlinti - iki XVII-XVIII a., galbūt išskyrus kai kuriuos 


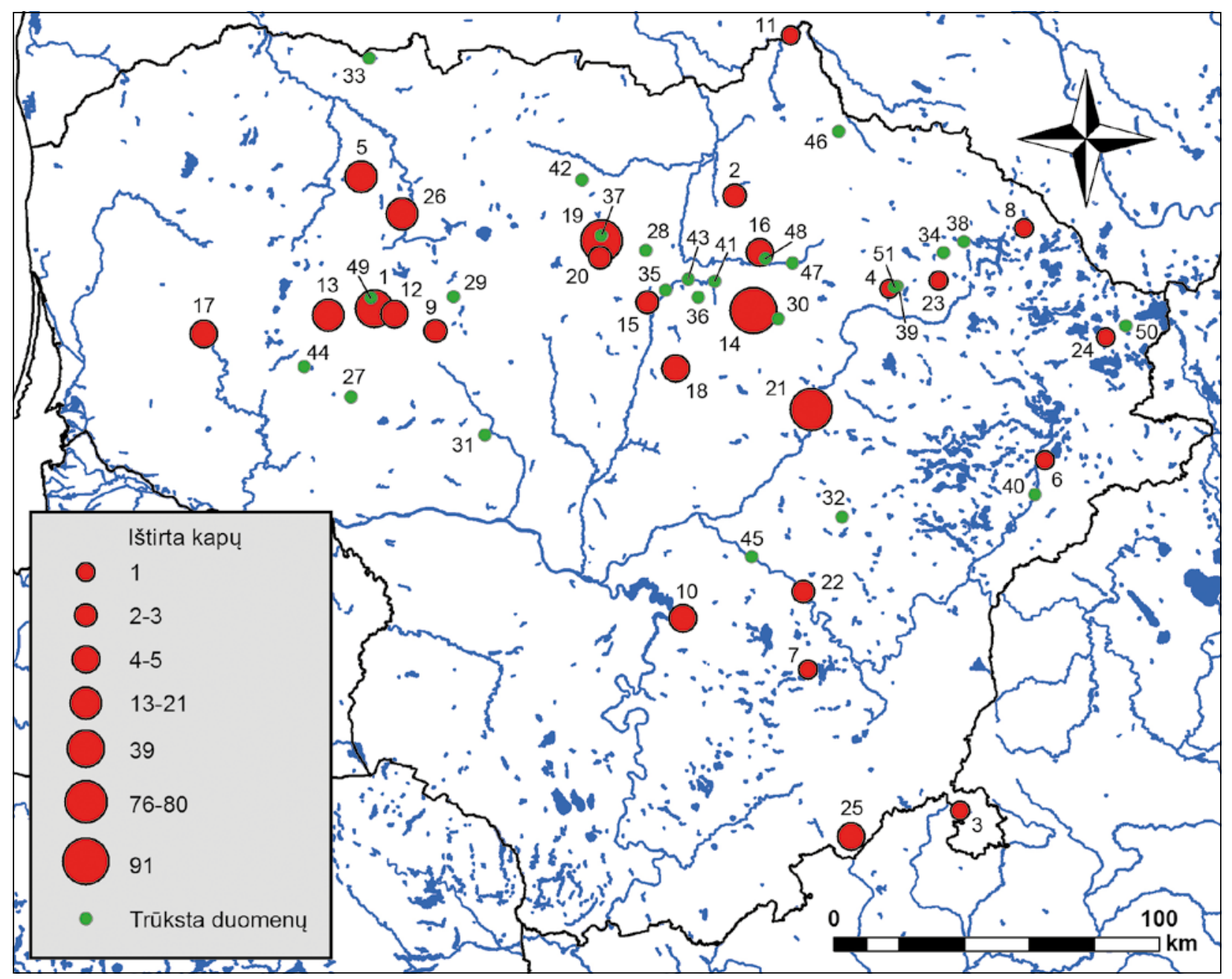

1 pav. Geležies amžiaus pilkapynai, kuriuose rasta vėlyvųjų viduramžių - ankstyvųjų naujųjų laikų kapų: 1 - Akmeniai, 2 - Berklainiai, 3 - Didžiuliai, 4 - Druskiai, 5 - Kybartiškè, 6 - Kretuonai I, 7 - Kurganai-Varatniškès, 8 - Lygalaukiai, 9 - MaironiaiSaudininkai, 10 - Maisiejūnai-Surgantiškès, 11 - Muoriškiai, 12 - Noruišiai, 13 - Paalksniai, 14 - Pajuostis, 15 - Pakalniškiai, 16 - Pamarnakis, 17 - Paragaudis, 18 - Pašiliai, 19 - Plaučiškiai, 20 - Raginėnai, 21 - Riklikai, 22 - Semeniškès, 23 - Vaineikiai, 24 - Vigodka-Dūkštas-Saksoniškès II, 25 - Vilkonys, 26 - Visdergiai-Papelkiai, 27 - Adakavas, 28 - Gilbonys, 29 - Jagminiškè, 30 - Juostininkai, 31 - Kejènai, 32 - Kiemeliai, 33 - Kivyliai, 34 - Kuokšiai, 35 - Lakštingalos, 36 - Lepšiai, 37 - Meldiniai, 38 - Mičiūnai, 39 - Miškiniai, 40 - Paduobė-Šaltaliūnè III, 41 - Pajuostis, 42 - Paliečiai, 43 - Pažalvaičiai, 44 - Požerè, 45 - Rusiai, 46 - Skrebiškiai, 47 - Skverbai, 48 - Tiltagaliai, 49 - Tolišiai, 50 - Visagina, 51 - Visètiškès. L. Kurilos brėž.

kapus greta buvusiuose pilk. II ir VII. Tačiau XIX a. šiose kaimo kapinèse greičiausiai nebelaidota, $\mathrm{XX}$ a. pradžioje jos jau buvo pamirštos, nes pilkapius, ieškodamas senienų, kasinėjo vietos dvarininkas (Tautavičius 1969, p. 1-2, 43).

Suardytame Plaučiškių pilkapyne (Pakruojo r.) ištirti 7 pilkapiai ir vienas plotas tarp jų. Aptikta IV-V a. kapų ir 76 palaidojimai, ị sampilus ịkasti ankstyvaisiais naujaisiais laikais (2, 3 pav.). Visi individai buvo palaidoti $\mathrm{V}$ ar jai artima kryptimi (vieninteliame pilk. VII k. 15 - galva ị R). İkapès labai negausios ir tarp jų iš esmès nebuvo daiktų, kuriuos būtų galima laikyti tikromis ịkapèmis, o ne kasdieniais reikmenimis. Tikromis įkapemis laikytinos nebent monetos. Pagal jas kapai datuoti XVIXVII a. (Patkauskas 1979a). Šioje vietoje buvusiose 


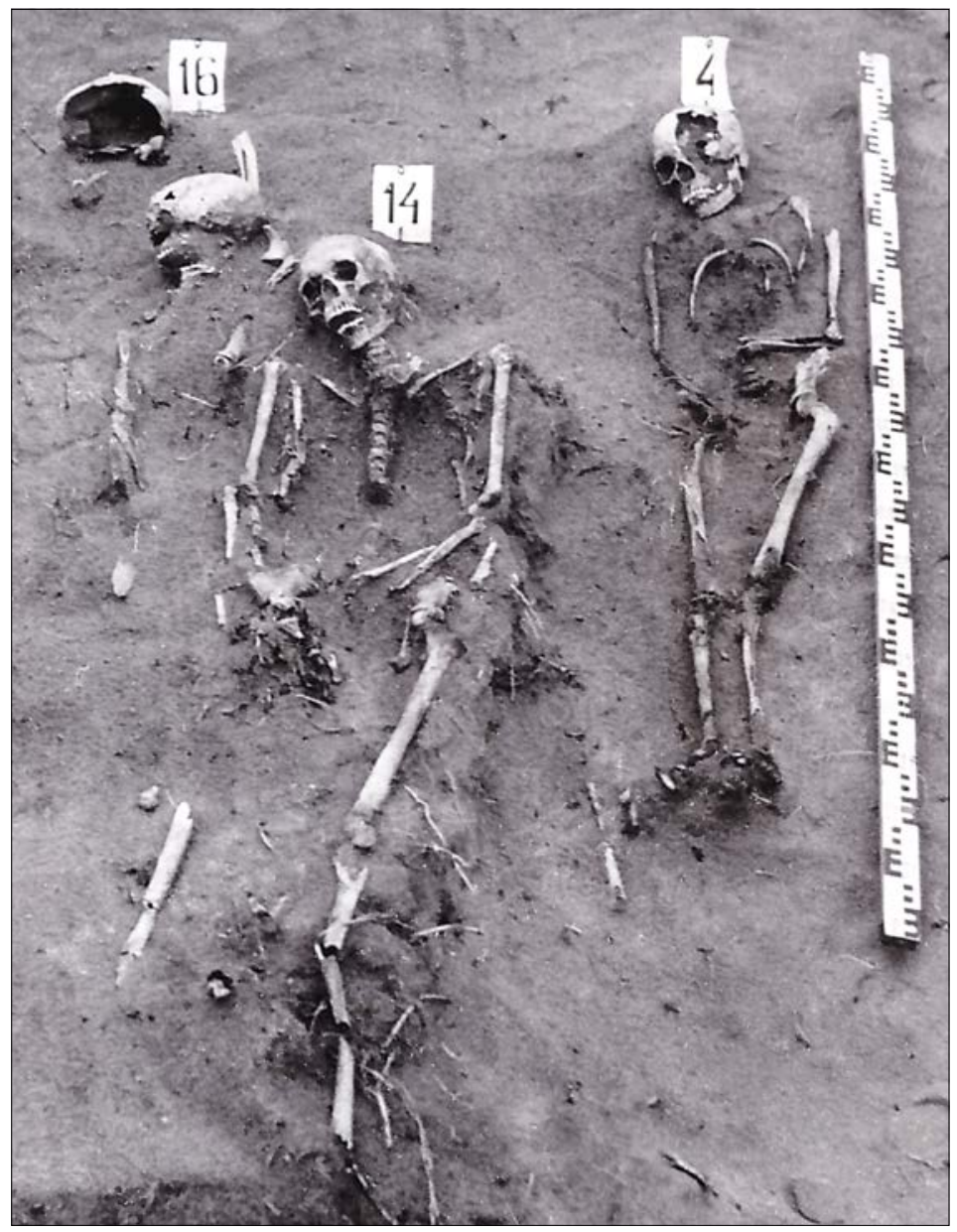

2 pav. Plaučiškių pilkapyno pilk. IV k. 4, 14-16 (Patkauskas 1979b, pav. 54).

netraukti. Be to, visuose ištirtuose 5-iuose pilkapiuose aptikta ir ịkapių iš suardytų XVI-XVIII a. kapų, taigi jų būta ir daugiau. Pilk. I rasta 10 kapų, kurių chronologija greičiausiai neišeina iš XVI a. ribų. Pilk. II buvo trys gausūs ịkapių XV a. pabaiga - XVI a. datuojami kapai ir dar vieno suardyto greičiausiai vèlyvo kapo liekanos. Net 16 XVI a. palaidojimų aptikta pilk. III, tiesa, kelių suardytų kapų datavimas - neaiškus. Dar 9 vèlyvesnio etapo (XVII-XVIII a.) kapai ištirti pilk. IV (Michelbertas 2006, p. 127-140). Mirusieji buvo palaidoti ivairiose sampilų vietose apie 0,7-1,6 $\mathrm{m}$ gylio duobèse, dalis - mediniuose karstuose. Vyravo krikščioniška kapų orientacija galvomis i $\mathrm{V}$, daugelis - su nuokrypiu i VPV ir PV, rečiau - $\mathfrak{i}$ VŠV ar ŠV. Vos du mirusieji buvo orientuoti i PPV, vienas - i RPR. Kai kurie kapai buvo suardyti, tikètina, laidojant kitus mirusiuosius. Pvz., pilk. I k. 5 ir pilk. IV k. 38 (17) kaulai ne anatominejje padètyje buvo sudèti nedidelèse duobutèse (Michelbertas 2006, p. 129, 139). Konstrukcija išsiskyrè pilk. III k. 30 (20), ku-

kapinaitėse, matyt, laidota ir vèliau - dar XX a. ant pilkapių buvę kryžių (Patkauskas 1979a, p. 4). Nurodoma, kad keli vėlyvi kapai Plaučiškių pilkapyne buvo rasti ir XX a. pradžioje (Svetikas 2003, p. 18), nors juos kasinèjęs Jonas Basanavičius (1936, p. 119) nepateikia duomenų būtent tokiam kapų datavimui.

Akmenių pilkapynas (Kelmès r.) taip pat ilgainiui jau buvo tapęs naujųjų laikų senkapiu ir dar maždaug prieš šimtmetị naudotomis kaimo kapinaitèmis. Čia 4-iuose senojo geležies amžiaus pilkapiuose aptikti 39 kapai, datuojami XV a. pabaiga - XVIII a. Pilk. V perkasoje atidengta dar 17 vèlyviausio etapo (XIX a. pabaigos - XX a. pradžios) kapų, kurių aplinkoje tebestovejjo keli kryžiai (Michelbertas 2006, p. 108). Pastarieji kapai i straipsnyje aptariamų sąrašą riame ant mirusiojo ị duobę buvo suversta per šimtą akmenų. İdomu, kad būtent šis kapas išsiskyrè ir neiprasta P krypčiai artima orientacija (Michelbertas 2006, p. 138). Atskirai paminètina tai, kad bent vienas asmuo, pilk. I k. 3 palaidota jauna moteris, pagal gintarinị signetinị žiedą su „Aksak“ herbu ir monograma (Michelbertas 2006, p. 123) galbūt priskirtina bajorijos luomui.

Kelios dešimtys vėlyvų kapų rasta senojo geležies amžiaus Paalksnių pilkapyne (Kelmès r.), kurio teritorijoje laidota ir vèlyvajame geležies amžiuje. Nuo pagrindinès pilkapių grupès kiek nutolusiame pilk. XXI, datuojamame I a. 2-ąja puse - III a. pradžia, sampilo centrinèje ir Š dalyje, aptikta mažiausiai 13 vèlyvų kapų. Laidota ịvairiomis, išskyrus $P$, 
kryptimis. Palaidojimų pilkapio plote daug, tad nemažai jų buvo apardyti kasant duobes vèlesniems kapams. Tai leidžia manyti, kad kapų vietos žemės paviršiuje nebuvo kaip nors pažymètos. Pagal būdingas ịkapes kapai datuojami XV, galbūt ir XVI a. (Michelbertas 2011, p. 159173). Dar 24 panašiu laikotarpiu datuojami kapai ir suardytų kapų liekanų rasta pilk. XXI aplinkoje, $\mathfrak{i}$ R nuo jo (Michelbertas 2011, p. 173-209).

Kybartiškès pilkapyne (Šiaulių r.) 4-iuose I-III a. pilkapiuose aptiktas 21 vèlyvas kapas ir dar kelių kapų liekanų (Michelbertas 1970a). Mirusieji palaidoti su negausiomis ikapèmis, dauguma galva artimomis V kryptimis. Sprendžiant iš kapų, kuriuose rasta monetų, senkapis pilkapyne ikurtas XVI-XVII a. (Michelbertas 1970a, p. 30-31), jame laidota dar iki XX a. Per tą laiką daugelis kapų buvo suardyti kasant duobes dar vèlesniems.

Senojo geležies amžiaus Visdergių-Papelkių pilkapyno (Šiaulių r.) pilkapiuose ir šalia jų rasta mažiausiai 13 vèlyvų kapų, nors dali pilkapiuose buvusių palaidojimų sudètinga priskirti vienam iš dviejų laidojimo etapų. Pilk. B buvo 4 griautiniai kapai (Dowgird 1888, p. 7-8, Tab. II:4a,

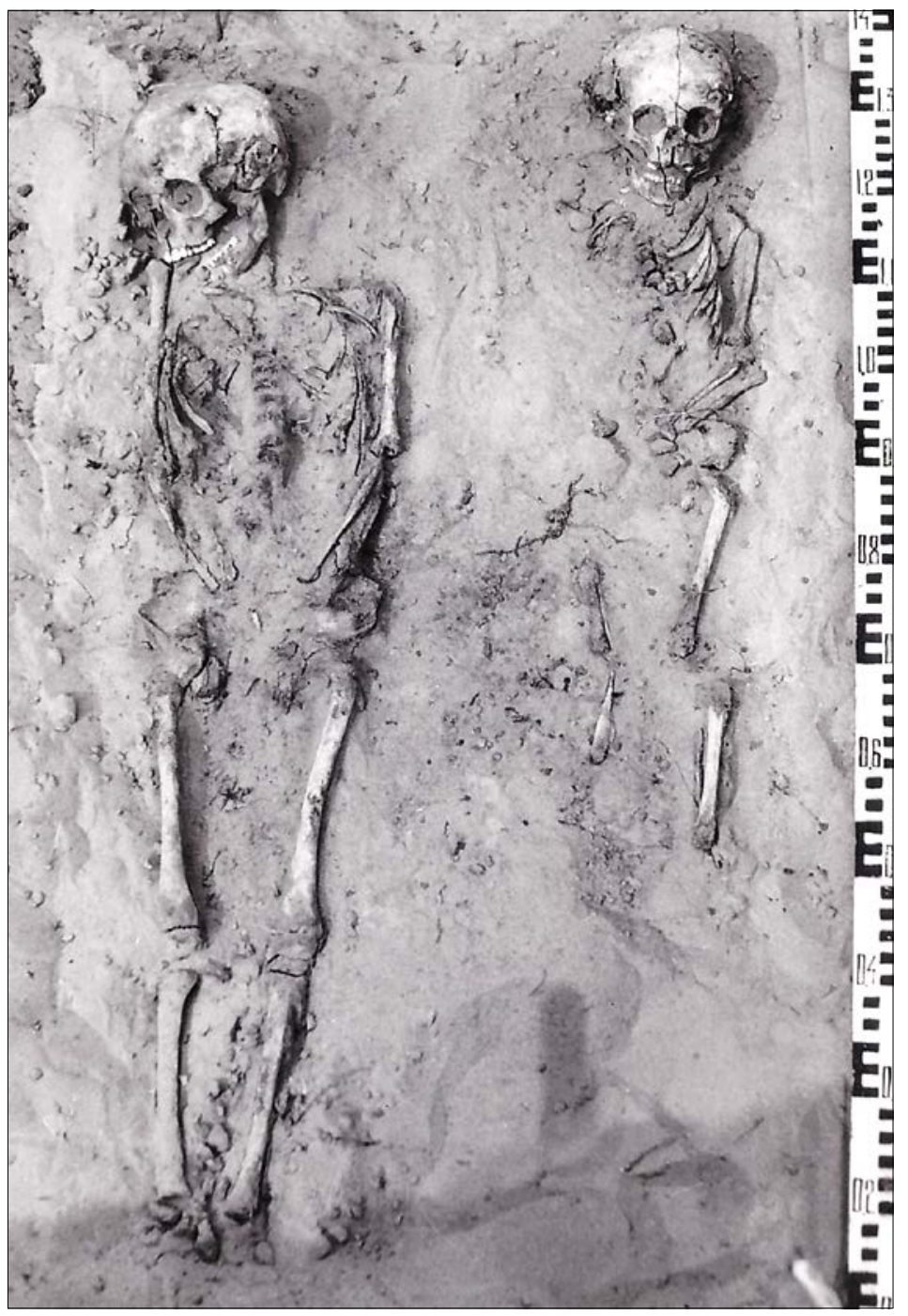

3 pav. Plaučiškių pilkapynas, plotas tarp pilk. III ir VII, k. 5, 6 (Patkauskas 1979b, pav. 126).
6, VI:6-11), bent vienas iš jų (k. d) pagal įkapes datuotinas XIV pabaiga - XVI a. pradžia (žr. Svetikas 2009, p. 269-278, 363-365, 373). Dviejų kapų (b ir c), buvusių be ịkapių, datavimas lieka neaiškus, tačiau vieną jụ galima datuoti netiesiogiai. Sprendžiant pagal k. c ir d padèti (mirusieji, orientuoti ŠŠV kryptimi, greičiausiai buvo paguldyti vienoje duobeje kiek ịstrižai, galva aukščiau nei kojos), manytina, kad jie - vienalaikiai. Pilk. C, D, F, G, K, be aiškiai senuoju geležies amžiumi datuotų kapų, irgi aptikta kapų be įkapių (Dowgird 1888, p. 8-9, 12-13). Teigiama, kad tai gali būti XVI-XVII a. palaidojimai
(Svetikas 2003, p. 16), vis deltto jų priskyrimas prie vèlyvųjų niekuo neparemtas. Dar viename, ištirtame beveik po šimtmečio, pilkapyje moteris palaidota sampilo centre galva ị P (Markelevičius 1974, p. 5-6). Pagal ikapes kapas datuotas XIV-XV a. (Markelevičius, Olišauskas 1974, p. 101-102). Šalia pilkapių buvo ir to paties laiko senkapis. Čia aptikta dar 10 kapų bei pavienių dirbinių iš suardytų kapų (Markelevičius 1974, p. 7-13). Laidota galvomis ị V. Kapai datuoti XV-XVI (Markelevičius, Olišauskas 1974, p. 102), galbūt ir XVII a. Taigi kapus pilkapiuose 
reikètų vertinti ne kaip lokalų reiškinị, o kaip senkapio erdvès pletrą i seno pilkapyno teritoriją arba, atsižvelgus ị kapų chronologiją, labiau tikètina, laidojimo, prasidejjusio nuo kelių kapų senuose pilkapiuose, tąsą sampilų aplinkoje.

Bent keli ankstyvųjų naujųjų laikų kapai aptikti ịkasti ị pilkapius senojo geležies amžiaus Pakalniškių pilkapyne (Panevėžio r.), 1897 m. tyrinètame Marios Butrymównos (Majewski 1900; Спицынъ 1902). Tačiau prasta tyrimų fiksacija ir lakoniška dokumentacija neleidžia daugelio kapų priskirti vienam iš dviejų laidojimo etapų. Pilk. 3 rastas senojo geležies amžiaus kapas ir dar vienas palaidojimas, pagal monetas (viena - $1568 \mathrm{~m}$.) datuotinas XVI a. 3-iuoju trečdaliu (Majewski 1900, p. 92-93). Kituose pilkapiuose buvo iki 7-ių kapų - dalis aiškiai datuoti senuoju geležies amžiumi, kitų chronologija neaiški. Tikètina, kad dar keli ar keliolika asmenų sampiluose galèjo būti palaidoti istoriniais laikais. Deja, neturima beveik jokių duomenų apie 1893-1894 m. Romano Aleknos Szwoynickio čia ištirtus per 20 pilkapių (Спицынъ 1902, p. 95). Jo senienų, aptiktų Pakalniškių pilkapyne, rinkinyje, be kitų radinių, buvo ir monetų (Banytė ir kt. 2016, p. 278), greičiausiai rastų vèlyvuose kapuose. Dar vieną monetą - Jono Kazimiero šilingą - pilkapyje 1909 m. aptiko Ivanas Abramovas (Simniškytė 2011, p. 189). Apibendrinant šiuos duomenis galima teigti, kad Pakalniškių pilkapiuose aptikti mažiausiai trys XVI-XVII a. kapai, tačiau tikètina jų buvus gerokai daugiau. Galbūt čia plytėjo ir nemažas senkapis.

Maisiejūnų-Surgantiškių pilkapyno (Kaišiadorių r.) pilk. 5 (41) rasti 5 vèlyvi kapai. Jo R pakraštyje buvo užkasti vieno suaugusio asmens, dviejų vaikų ir dviejų naujagimių palaikai be ịkapių, visi orientuoti VPV kryptimi (Butėnas 1998, p. 175). Tyrimų autorè šiuos kapus ịvardijo nekrikštų kapinèmis (Butėnienè 1971, p. 12). Verta paminèti ir pilk. 9 (14), supilto I t-mečio viduryje, $\mathrm{P}$ pakraštyje, ant vainiko akmenų rastą degintinị kapą su ankstyviesiems senkapiams būdingais radiniais: skiltuvais, plačiaašmeniu kirviu ištęstais ašmenimis, ietigaliu žemo rombo formos plunksna ir kt. (Butènas 1998, p. 168-169, 176-177). Tyrimų publikacijoje nurodomas kapo datavimas XI-XII a. (Butėnas 1998, p. 172), ji patvirtintų ir ${ }^{14} \mathrm{C}$

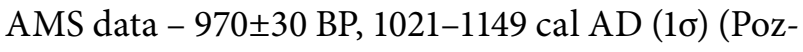
63949) (Kurila 2015, p. 64, lent. 3), nors radinių tipologija neleidžia atmesti ir datavimo XIII a. galimybės (Kurila 2003, p. 30; 2015, p. 58; Petrauskas 2017, p. 62-63) (tokią prieštarą radiokarboninei datai galètų paaiškinti tikètinas gèlo vandens rezervuaro arba seno medžio efektas). Akivaizdu, kad kapas ne tik yra daug vèlesnis už pilkapyną, bet ir apskritai nebepriklauso Rytų Lietuvos pilkapių kultūrai būdingos laidosenos laikotarpiui. Vis dèlto, atsižvelgiant ị radiokarboninę datą, ji reikètų laikyti daugiau laidojimo pilkapiuose tradicijos atgarsiu, nei grịžimu prie senosios tradicijos viduramžiais. Todèl šis kapas $\mathfrak{i}$ straipsnyje nagrinejjamų sąrašą neįtrauktas.

Pamarnakio pilkapyne (Panevėžio r.) rastas mažiausiai vienas kapas, pagal monetas datuotinas XVII a. 2-ąja puse, tačiau pilkapius kasinèjęs I. Abramovas dar bent tris kapus įvardijo kaip vėlyvus, o dar viename pilkapyje rasta karsto vinis (Simniškytè 2011, p. 190-191) irgi laikytina laidosenos istoriniais laikais ženklu.

Tris iš 80-ies Raginènų pilkapyne (Radviliškio r.) aptiktų kapų pagal kaulų būklę I. Abramovas irgi priskyrè vèlyviesiems. Dveji iš griaučių buvo nebūdingoje padètyje - vienas mirusiųjų buvo suriestas, o kitas paguldytas ne horizontaliai - galva žemiau kojų (Simniškytė 2011, p. 198).

Idomių duomenų suteikè Vilkonių pilkapyno (Šalčininkų r.) tyrinejjimai XIX a. pabaigoje (Шукевич 1893, p. 99; 1897, 1. 21-65). Deja, to meto dokumentacijos lygis neleidžia gerai suprasti šio laidojimo paminklo raidos. Atrodo, Wandalino Szukiewicziaus neatskirti ir i jo sudarytą planą (Шукевич $1897,1.65)$ kartu pateko ir viduramžių jotvingiški iš akmenų sukrauti kapai, ir I t-mečio vidurio pilkapiai su degintiniais kapais. Daugelis ištirtų kapų su XIII-XV a. būdingomis ịkapèmis (plačiaašmeniais 
kirviais, trikaroliais antsmilkiniais, apgalviais, kaklo apvaromis iš stiklo karolių, žvangučių ir kauri kriauklelių, lietuviška monetèle ir kt.) rasti po pailgomis akmenų krūsnimis. Tačiau keli buvo ịkasti $\mathfrak{i}$ ankstyvesnius pilkapius. $1891 \mathrm{~m}$. ištirtame pilkapyje rasti trys griautiniai kapai be ịkapių ir degintinis kapas su siauraašmeniu kirviu (Шукевич 1893, p. 99). 1894 m. kasinètame pilk. 2 (6) buvo degintinis kapas su ietigaliu ir peiliu bei griautinis palaidojimas be ikkapių (Шукевич 1897, 1. 21-22). Greičiausiai geležies amžiaus pilkapynas po kelių šimtmečių pertraukos vèl tapo laidojimo erdve, mirusiuosius čia pradejus laidoti būdinguose viduramžių jotvingiškuose iš akmenų sukrautuose kapuose. Tačiau ar būtent viduramžiais reikètų datuoti ir minètus kapus pilkapiuose - neaišku. Neatmestina, kad jie galejjo būti ịkasti ị sampilus trečiajame laidojimo etape - ankstyvaisiais naujaisiais laikais.

Pirmaisiais amžiais po Kr. datuojamuose Paragaudžio pilkapiuose (Šilalès r.) rasti keli suardyti vèlyvi palaidojimai. Pilk. XXXII buvo du XV-XVI a. ar vèlesni kapai ir dar kelių panašios chronologijos kapų liekanų (Michelbertas 1992, p. 6-8; 1997, p. 62), o pilk. XXXV - vieno XVII a. kapo liekanos (Michelbertas 1997, p. 63).

Sunaikintų Noruišių pilkapių (Kelmès r.) liekanose aptikti 4 kapai, pagal juose buvusias monetas datuoti XVII a. (Markelevičius 1977a, p. 63-67). Kadangi sampilai jau buvo visiškai suardyti, kapų padètis (pilkapiuose ar tarp jų) neaiški. Tik pagal šalia aptiktą gausų ịkapių III-IV a. kapą galima numanyti, kad vèlyvi palaidojimai buvo pilkapio sampile.

Ištirtame viename iš 7-ių išlikusių pilkapių Pašilių pilkapyne (Panevėžio r.) rasti 4 kapai. Pagal juose ir atsitiktinai pilkapiuose rastas monetas jie datuoti XVII a. (Markelevičius 1977c, p. 29-33).

Buvusiame Maironių-Saudininkų pilkapyne (Kelmès r.) pilkapių jau nebuvo (anksčiau čia jų būta apie 30 ), aptikta tik pavienių I t-mečio vidurio radinių. Ištyrus dvi perkasas, čia rasti trys kapai, kuriuos tyrèjas datavo XVII a. (Markelevičius 1977a, p. 5962). Jų chronologija gali būti ir kiek platesnè.

Berklainių pilkapyne (Pasvalio r.) ištyrus paskutinị išlikusị pilkapi su 8-iais III-VI a. kapais, aptikti du palaidojimai, tyrèjo datuoti XVI-XVII a. (Michelbertas 1970b, p. 7-8). Netoli pilkapio, galbūt buvusio pilkapyno teritorijoje, visiškai suardytoje jo dalyje yra kaimo kapinaitès. Taigi ši vieta gali būti dar vienas senkapio, ikurto pilkapyne, pavyzdys.

Du vèlyvi, XV-XVII a., kapai ištirti ir trečio kapo kontūrai užfiksuoti viename iš III-IV a. pilkapių Semeniškių senovès gyvenvietės II (Širvintų r.) teritorijoje (Baltramiejūnaitè 2011, p. 27-28). Sunku pasakyti, ar kapai buvo įkasti ị tuomet dar ryškiai matytus sampilus, ar jau nuartose jų vietose. Palaikai rasti gana giliose $(0,7 \mathrm{~m}$ gylio nuo dabartinio žemès paviršiaus) duobèse, o tai netiesiogiai liudija, kad sampilai jas kasant jau buvo arba suplokštèję, arba visiškai sunaikinti.

Vigodkos-Dūkšto-Saksoniškių pilkapyne II (Ignalinos r.) griautinis vyro kapas buvo ịkastas I t-mečio vidurio pilkapio su degintiniais kapais centre. Kūnas gulèjo galva ị VŠV. Pagal būdingą i kapių kompleksą jis datuotinas XIV a. pabaiga - XV a. (Kurila ir kt. 2007, p. 156-158, 165).

Vaineikių pilkapyne (Rokiškio r.) ištirtame III$\mathrm{V}$ a. pilkapyje aptikti du šio laikotarpio kapai ir vienas pačiame sampilo centre įkastas vaiko kapas be ¡̇kapių. Sprendžiant iš daug geriau nei senojo geležies amžiaus palaidojimuose išlikusių kaulų manytina, kad tai - istorinių laikų kapas. Mirusysis orientuotas galva ị Š (Simniškytė 1998).

Prie Kurganų ir Varatniškių kaimų (Trakų r.) buvusiame pilkapyne ištirti keturi I t-mečio vidurio pilkapiai su degintiniais kapais. Vieno iš jų sampile negiliai (virš akmenų, kurių buvo daug pilkapio sampile) aptiktas ikkastas griautinis kapas be ịkapių (Tautavičius 1951, p. 11). Laidota galva į V. Pagal greta griaučių buvusias kaltines karsto vinis ji galima tik apytiksliai datuoti ankstyvaisiais viduramžiais ar, labiau tikètina, naujaisiais laikais. 


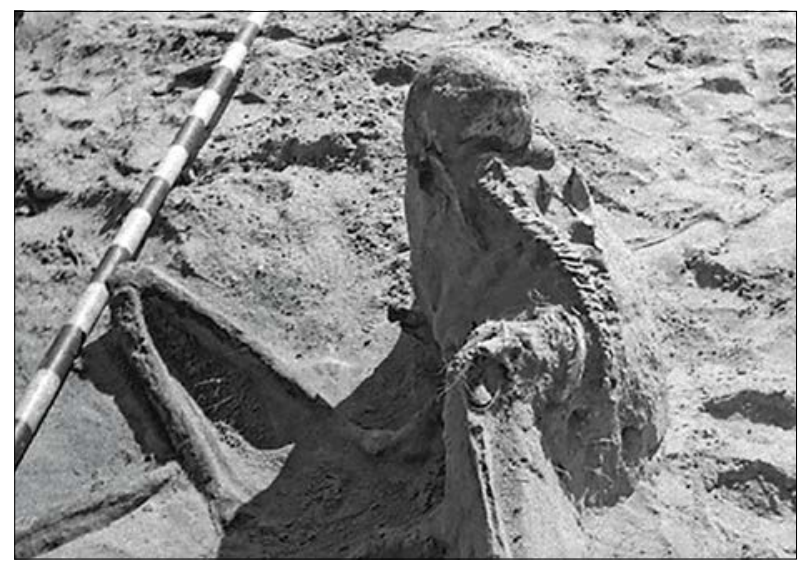

4 pav. Griautinis palaidojimas Didžiulių pilk. 11 (LIIR, neg. nr. 1766). A. Tautavičiaus nuotr.

Vèlyvas, datuotas XVII-XIX a., palaidojimas greta 7-ių senojo geležies amžiaus kapų buvo Muoriškių pilkapyje (Biržų r.) (Markelevičius, Morauskienė 1977, p. 93). Tokí datavimą patvirtina ne radiniai, o šautinè žaizda kaukolèje (Markelevičius 1977b, p. 12-13).

Druskių senkapyje (Kupiškio r.) pastebėta nežymių kauburèlių, kurie palaikyti suplokštejjusiais pilkapiais. Prie vieno iš jų aptiktas XVII a. 2-ąja puse datuotinas kapas. Moters pakaušyje buvo nedidelè skylutè - tikètina, šautinè žaizda (Girininkas 1976). Ar čia tikrai būta pilkapyno, nevisiškai aišku, tačiau tai patvirtintų aptikti degintiniai kaulai (Tebelškis 2000, p. 331).

Neịprastas palaidojimas aptiktas Didžiulių pilkapyne (Šalčininkų r.), kuriame ištirti keli vèlyvojo geležies amžiaus pilkapiai su degintiniais žmonių ir žirgų kapais. Vieno centre iškastoje nedidelèje duobèje beveik dvilinkas, kniūbsčias, pasuktu liemeniu, lyg sėdomis buvo ìspraustas asmuo galva nulenkta galva veidu žemyn (4 pav.). Ant galvos jam buvo užmestas vidutinio dydžio akmuo. İkapių neaptikta (Tautavičius 1952, p. 14).

Kretuonų I pilkapyne (Švenčionių r.) vėlyvojo geležies amžiaus pilkapyje su griautiniu žirgo kapu sampilo R pakraštyje, griovyje, rastas griautinis palaidojimas. Kaulai buvo sudèti nedidelèje duobèje.
Sprendžiant iš jų padèties (kaukolè ir dubenkaulis gulejo po ilgaisiais kaulais, kaukolès viduje - dubenkaulio dalis ir vienas slankstelis) galima manyti, jog tai antrinis palaidojimas - užkasti jau skeletuoti kaulai (Semènas 1995, p. 6). Kapo chronologija neaiški, LDK laikotarpiu ji galima datuoti tik sąlygiškai, bet jis gali būti ir dar vèlyvesnis.

Suardytų pilkapių vietoje Lygalaukių kaime (Zarasų r.) aptiktas jaunos moters kapas. Ji ị duobę buvo ìstumta galva žemyn beveik vertikaliai, sulenktomis kojomis. Tyrèjų įsitikinimu, kapas vèlyvas, nesusijęs su pilkapynu (Tautavičius, Urbanavičius 1978, p. 57). Tikslesnis jo datavimas liko neaiškus, taip pat neaišku, ar jis buvo įkastas i pilkapi, tarp pilkapių, ar jiems jau buvus sunaikintiems.

Daugiau ar mažiau patikimų duomenų turima apie kai kuriuose pilkapynuose aptiktus galbūt vèlyvus palaidojimus. Tačiau tiek dèl suardymų, tiek dèl menkos dokumentacijos jų nepakanka šiems objektams ịtraukti ị duomenų bazę. Kalvių (Kivylių) senkapyje (Akmenès r.) aptikta 15 XVI-XVII a. kapų ir radinių iš suardytų kapų. Tyrimų plote buvo ir II-III a. dirbinių bei, tikètina, pilkapių akmenų vainikų liekanų (Cholodinska 1978). Taigi šioje vietoje istorinių laikų kapai irgi galejo būti įrengti pilkapyne ar suardyto pilkapyno vietoje. Tačiau abiejų etapų kapų erdvinis santykis lieka aiškiai neapibrèžtas.

Buvusiame pilkapyne prie Visaginos kaimo (Visagino sav.) ištirti griautiniai kapai (Žiogas 1909, p. 14-15; Balčiūnas 1987, p. 87) be aiškios argumentacijos įvardijami kaip vèlyvi (Lietuvos 1977, p. 124; Balčiūnas 1987, p. 87; Svetikas 2003, p. 31). Remiantis skirtingais šaltiniais, čia galèjo būti aptikti 1-5 viduramžiais - naujaisiais laikais datuotini kapai. Nebaigtame kun. Juozapo Žiogo dienoraštyje apie Mičiūnų pilkapyno (Rokiškio r.) kasinejjimus aprašytas vienas kapas (Ostašenkovienè 2015, p. 127). Teigiama, kad pilkapyje aptikta XV-XVII a. radinių (Lietuvos 1977, p. 69). Lakštingalų kapinyne (Panevėžio r.) surinkta radinių iš suardytų kapų, datuojamų keliais 
etapais: II-VIII ir XIV-XVII a. (Petrulis 2018). Tai leidžia manyti, kad vèlyvas kapinynas galejo būti ¡kurtas pilkapyne arba suardyto pilkapyno vietoje. Turbūt šioje vietoje (ji nurodoma gretimo Nevėžninkų kaimo vardu) pilkapiai kasinèti XX a. pradžioje (Butrymówna 1902). Minima, kad XIV-XVI a. kapų būta Gilbonių pilkapyne (Panevėžio r.) (Lietuvos 1977, p. 40). Tačiau cituojamuose šaltiniuose aiškesnès tą patvirtinančios informacijos, išskyrus žinutes apie žmonių randamas senas monetas (Baltramiejūnas 1934; Tautavičius 1968, p. 52), nèra. Pažalvaičių pilkapyne (Panevėžio m.) ištirtame pilkapyje aptikti 7 kapai, kuriuos pagal viename jų rastą monetą reikètų datuoti XIX a. (Butènienè-Gintautaitè 1961). Tikètina, kad šioje vietoje pilkapiuose laidota ir XVII-XVIII a. (Lietuvos 1977, p. 87), bet tai patvirtinančių duomenų nèra. Vèlyvų kapų aptikta Tiltagalių pilkapyne (Panevėžio r.). Viename pilkapyje atidengtos 3-ų kapų duobès, tačiau, konstatavus, kad tai veikiausiai XIX-XX a. palaidojimai, jie palikti netirti (Markelevičius 1977c, p. 38-39). Paduobès-Šaltaliūnės III (Švenčionių r.) pilk. 14 pakraštyje, duobeje, rastas griautinis kapas, ịrengtas greičiausiai XIX a. 2-ojoje pusėje - XX a. 1-ojoje pusèje (Steponaitis 2006, p. 89).

Neaiškiomis aplinkybėmis rasti vèlyvi kapai ar pavieniai radiniai minimi Jagminiškès (Kelmès r.), Juostininkų (Anykščių r.), Pajuosčio (Panevėžio r., Velžio sen.), Tolišių (Kelmès r.) pilkapynuose (Lietuvos 1977, p. 45, 48, 78, 114). Apie kelis vèlyvus senkapius, pvz., Adakavo (Tauragės r.), Kiemelių (Širvintų r.), Lepšių (Šiaulių m.), Meldinių (Pakruojo r.), Paliečių (Pakruojo r.), kurie, tikètina, buvo įrengti pilkapynų vietose, turima dar mažiau duomenų (Lietuvos 1977, p. 19, 54, 62, 68, 80). Kuokšių (Rokiškio r.), Skrebiškių (Biržų r.), Skverbų (Kupiškio r.) pilkapynuose rasta pavienių XIV-XVI a. dirbinių (Simniškytė 2013, p. 173, 261, 288-290). Keliose vietose pilkapynai ar žinomos jų vietos yra visai netoli senkapių, pvz., Kejènai, Požerè, Rusiai. Šiais ir panašiais atvejais neaišku, ar pilkapynų ir senkapių teritorijos praeityje persidengè, ar jų artumas yra daugiau atsitiktinis.

Diskutuotinos chronologijos kapų ištirta Visètiškių pilkapyne (Anykščių r.). Jie datuojami ir X-XII, ir XIII-XIV a. Pirmoji vèlyviausiojo etapo chronologija paremta radinių, tarp kurių iš tiesų nèra nė vieno aiškiai indikuojančio viduramžius, tipologija, antroji - radiokarbonine (tiesa, ne pačios geriausios reputacijos laboratorijos) data (plg. Kazakevičius 2000b, p. 81-82; Simniškytè 2013, p. 173). Skirtingas datavimas lemia ir neaiškų laidojimo paminklo raidos modelị - sèliškosios laidojimo tradicijos tąsa iki geležies amžiaus pabaigos ar christianizuojamos visuomenès sugrịžimas ị apleistą laidojimo vietą. Panašiai dviprasmiškas ir Miškinių pilkapyno (Anykščių r.) datavimas (plg. Kazakevičius 2000a, p. 81-82; Simniškytė 2013, p. 173).

Tačiau ir čia pateiktas sąrašas neabejotinai nebaigtinis. Vien dažni pasakojimai apie pilkapiuose tikrai ar tariamai randamus „senovinius pinigus“ leidžia manyti, kad jis galètų būti dar gerokai ilgesnis.

\section{KAI KURIE LAIDOSENOS BRUOŽAI}

Aptariamuosiuose kapuose buvo palaidoti vyrai, moterys (dauguma atvejų lytis nustatyta tik pagal įkapes) ir vaikai. Išskyrus kelis palaidojimus, kurie aptariami toliau, dauguma kapų yra tipiški vėlyvųjų viduramžių - ankstyvųjų naujųjų laikų senkapių kontekste. Maždaug pusėje kapų, kuriuose laidojimo orientacija nustatyta ir užfiksuota, kūnai buvo paguldyti galva V kryptimi, dauguma kitų artimais šiai krypčiai azimutais (5 pav.). Šiuo požiūriu išsiskyrè vienintelis Paalksnių kapinynas: jame daugiau nei pusè mirusiųjų laidoti $\mathrm{R}$ ar artimomis kryptimis. Ko gero, tai aiškintina sąlygišku kapų ankstyvumu ir dar nenusistovejusia krikščioniškąja laidojimo orientacija. Kai kuriuose kapuose aptikta karstų liekanų: lentų kontūrų, vinių ar kitų detalių (Maironių-Saudininkų k. 3 (perkasa II), Plaučiškių pilk. VII k. 8). Maironių-Saudininkų k. 1 


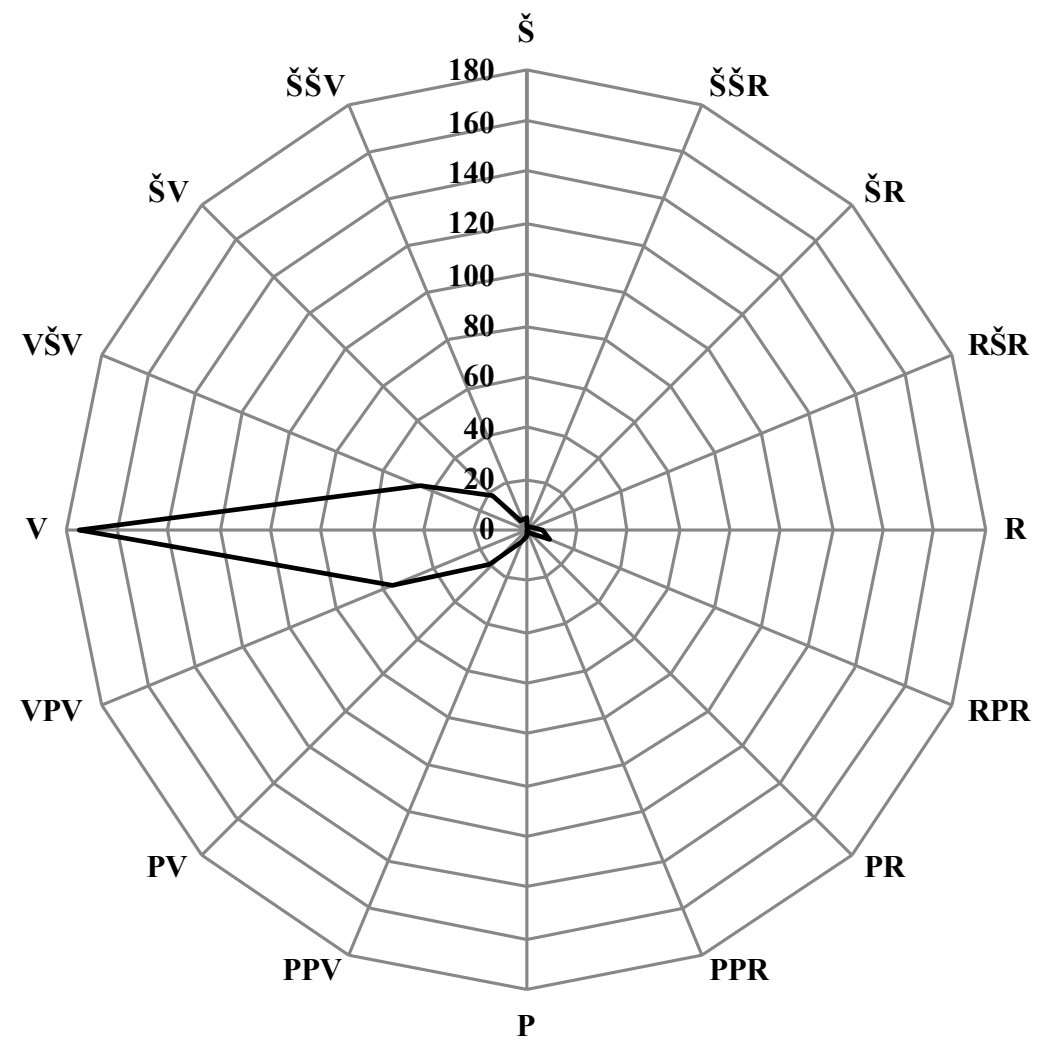

5 pav. Kapų orientacija. L. Kurilos bréž.
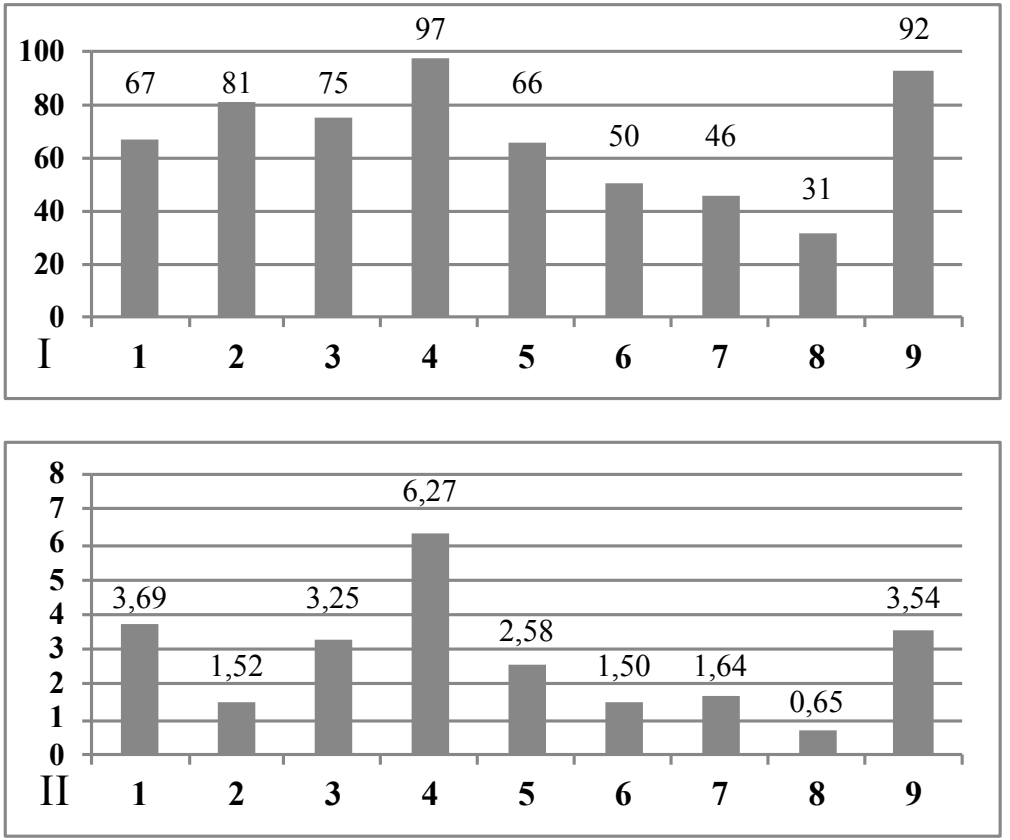

6 pav. Kapų su ịkapėmis nuošimtis (I) ir vidutinis ịkapių skaičius (II) pilkapynuose: 1 - Akmeniai, 2 - Kybartiškè, 3 - Noruišiai, 4 - Paalksniai, 5 - Pajuostis, 6 - Pašiliai, 7 - Plaučiškiai, 8 - Riklikai, 9 - Visdergiai-Papelkiai. L. Kurilos brèž. 
(perkasa I), Plaučiškių pilk. VI k. 14 ir 15 bei pilk. VII k. 20 laidota skobtiniuose karstuose.

Daug kapų buvo apardyti kasant duobes vèlesniems palaidojimams. Kai kurie kapai buvo visiškai sunaikinti - jau skeletuoti kaulai surinkti ir užkasti naujose duobutèse (pvz., Akmenių pilk. IV k. 38 (17), Kybartiškès pilk. I k. 6 ir pilk. II k. 1, Kretuonų pilk. 1 (55) k. 2). Didelis kapų tankumas, viena vertus, rodo stiprią aspiraciją laidoti būtent pilkapių sampiluose, kita vertus, palyginti ilgą laidojimo laiką bei tai, kad kapai greičiausiai nebūdavo aiškiai pažymimi žemès paviršiuje.

Ikapių aptikta daugiau nei pusèje kapų - 225-iuose. Kapų su ikapèmis nuošimtis pilkapynuose nevienodas - nuo mažiau nei trečdalio Riklikuose iki beveik visų Paalksniuose (6:I pav.). İkapių skaičius (tokius dirbinius, kaip karolių apvaros ar smulkios metalinės aprangos detalès, skaičiuojant kaip vieną) taip pat labai ivvairus - iki 15-os Akmenių pilk. IV k. 39 (18), 17-os Paalksnių k. 17 (perkasa IV), 18-os Paalksnių k. 27 (perkasa VI), 20-ies Plaučiškių pilk. VII k. 4, 22-ų Paalksnių k. 29 (perkasa VIII), Pajuosčio pilk. XIV k. 53 (J) ar 23-ų Pajuosčio pilk. 14 k. 50 (G). Jis labai skiriasi ir atskiruose pilkapynuose (6:II pav.).

Didžiausią ịkapių dalị sudaro monetos, aptariamuose kapuose jų rasta mažiausiai 300 (dalis buvo visiškai sunykusios, ir tikslaus skaičiaus nustatyti nepavyko). Jos sudaro apie 33\% visų ikapių, o Pajuosčio ir Plaučiškių pilkapynuose - absoliučią daugumą. Tai - monetos, apimančios laikotarpi nuo XV-XVI a. sandūros (Ldk Aleksandras, 14921506) iki XVII a. 2-osios pusès (Ldk ir Lenkijos karalius Jonas Kazimieras Vaza, 1648-1668; Prūsijos

hercogas Frydrichas Vilhelmas, 1640-1688; Švedijos karalius Karolis XI, 1660-1697). Kitos ịkapès pagal kategorijas pasiskirsto nevienodai (7 pav.), ir tai greičiausiai yra susiję pirmiausia su kapų chronologija, pvz., sąlygišką kapų ankstyvumą indikuojantis didelis pridètinių îkapių (darbo įrankių, ginklų) skaičius yra iš esmès atvirkščiai proporcingas monetų skaičiui. 


\section{LAIDOJIMO PILKAPIUOSE PAPROČIO PAPLITIMAS IR CHRONOLOGIJA}

Vèlyvųjų viduramžių ir ankstyvųjų naujųjų laikų kapai senuose pilkapiuose sudaro apie 4\% visų ištirtų to meto kapų (plg. Svetikas 2003, p. 15-40, lent. 1-8). Itvertinant tai, kad tik dalis Lietuvos bendruomenių apskritai turèjo tokią galimybę (visoje Vakarų, Pietvakarių ir Vidurio Lietuvoje pilkapynų, ịskaitant ir bronzos amžiaus, labai mažai, be to, ir kitur jų buvo ne kiekvienos bendruomenès artimiausioje aplinkoje), laidojimą senuose pilkapiuose galima laikyti išskirtiniu, tačiau gana dažnu, kai kuriuose regionuose netgi masiniu laidojimo būdu.

Tikruoju laidojimo priešistoriniuose pilkapiuose papročio paplitimo arealu reikia laikyti Žemaitiją ir Šiaurès Lietuvą - teritoriją nuo Šventosios rytuose, apimančią Lèvens, Nevèžio aukštupio, Dubysos aukštupio, Ventos aukštupio ir Virvytès baseinus, iki Jūros aukštupio vakaruose (8 pav.). Ją V ir P puseje natūraliai apibrèžia senojo geležies amžiaus Žemaitijos ir Šiaurès Lietuvos pilkapių arealo ribos, $\mathrm{R}$ pusẻje ji irgi iš esmès sutampa su šios kultūros riba, o Š pusejje ribos vaizdą veikiau sukuria tiesiog mažesnès tyrimų apimtys toliausiai ị Š esančiuose Lietuvos pilkapynuose. Nors šioje teritorijoje bendras pilkapynų tankumas ir gerokai mažesnis nei Rytų Lietuvoje, čia ne tik susitelkusi didžioji dalis tokių kapų radimo vietų, bet yra ir visi pilkapynai, kuriuose jų aptikta daugiausia. Istoriniu požiūriu ši teritorija apėmė LDK Vilniaus vaivadijos ŠV dalị, Trakų vaivadijos Š dalị ir Žemaičių seniūnijos ŠR dalị (maždaug po 1564-1566 m. pavietų reformos išskirtose Ukmergès, Upytės pavietų teritorijose ir dalyje Žemaičių seniūnijos valsčių).

Idomu, kad istorinių laikų palaidojimų pilkapiuose palyginti reta Rytų Lietuvoje, kurioje pilkapynų daugiausia, o ir jų tyrimų apimtys čia buvo didžiausios. Rytų Lietuvoje tokių kapų aptikta vos po vieną (pvz., Vigodka-Dūkštas-Saksoniškès II) ar kelis
(Maisiejūnai-Surgantiškès, Semeniškès). Be to, būtent šiame regione jie turi daugiau požymių, indikuojančių „kitokią“ laidoseną (žr. toliau).

Tačiau nei dabartinè Lietuvos, nei buvusi LDK šiaurinė siena nebuvo šio papročio sklaidos riba. XIIIXIX a. kapu pilkapiuose aptikta ir Latvijoje - anuometineje Livonijoje, daugiausia Dauguvos baseine (Šnore 1993, p. 72-75; Simniškytė 2013, p. 173-174; Muižnieks 2015, p. 229-233, att. 6, tab. 3). Daugeliu atvejų aptikta po vieną ir kelis, bet kai kuriuose pilkapynuose (pvz., Ķunci, Ratulāni, Zvanītāji) - dešimtys vèlyvų kapų. Tiesa, čia šio papročio raida yra ne tokia aiški. Sèloje ir Latgaloje, kur laidojimo pilkapiuose tradicija gyvavo ilgiau nei Lietuvoje, galbūt netgi iki XIII-XIV a. (Šnore 1993, p. 72-75; Radinš 1999, p. 52; Simniškytė 2013, p. 173-174), susidaro jos tęstinumo iki pat XVIII-XIX a. regimybè, kurią gal kiek paryškina ir nepakankamai tiksli kapų chronologija. Regiono mastu vèlyviausia sèliškojo ir latgališkojo etapo pilkapynų bei pakartotinio laidojimo juose fazès, atrodo, yra chronologiškai labai artimos, o galbūt netgi persidengia. Tačiau lokaliu lygmeniu, atskiruose pilkapynuose ar pilkapiuose, nepertraukiamo laidojimo nuo vèlyvojo geležies amžiaus iki naujųjų laikų neužfiksuota.

Pažymėtina, kad istorinių laikų papročio laidoti pilkapiuose sklaida neapsiribojo ir baltų etnine erdve. I R nuo Lietuvos, dabartinejje Šiaurès vakarų Baltarusijoje, Breslaujos ežeryno, Dauguvos-Dvinos regione ir (rečiau) kitur, slaviškojoje LDK dalyje, patekusioje i Vilniaus ir Polocko vaivadijas, ištirta pavienių XVI-XVII a. kapų, kapų ikkastų i ankstesnius pilkapius, esama kapinynų tarp pilkapių. Čia ši tradicija peraugo ị pagarbą pilkapiams, kaip sudedamąją mirusiųjų kulto dalį, ant jų statyti akmeniniai kryžiai (Дучыц 1997; Чараўко 2010).

Chronologiniu požiūriu aptariamus ankstyviausius istorinių laikų kapus senuose pilkapiuose išskirti sunku. Kaip minèta, palaidojimai ankstesniuose pilkapiuose buvo nereta viso priešistorinio laikotarpio praktika Lietuvoje, galbūt nusitęsusi ir $\mathfrak{i}$ 


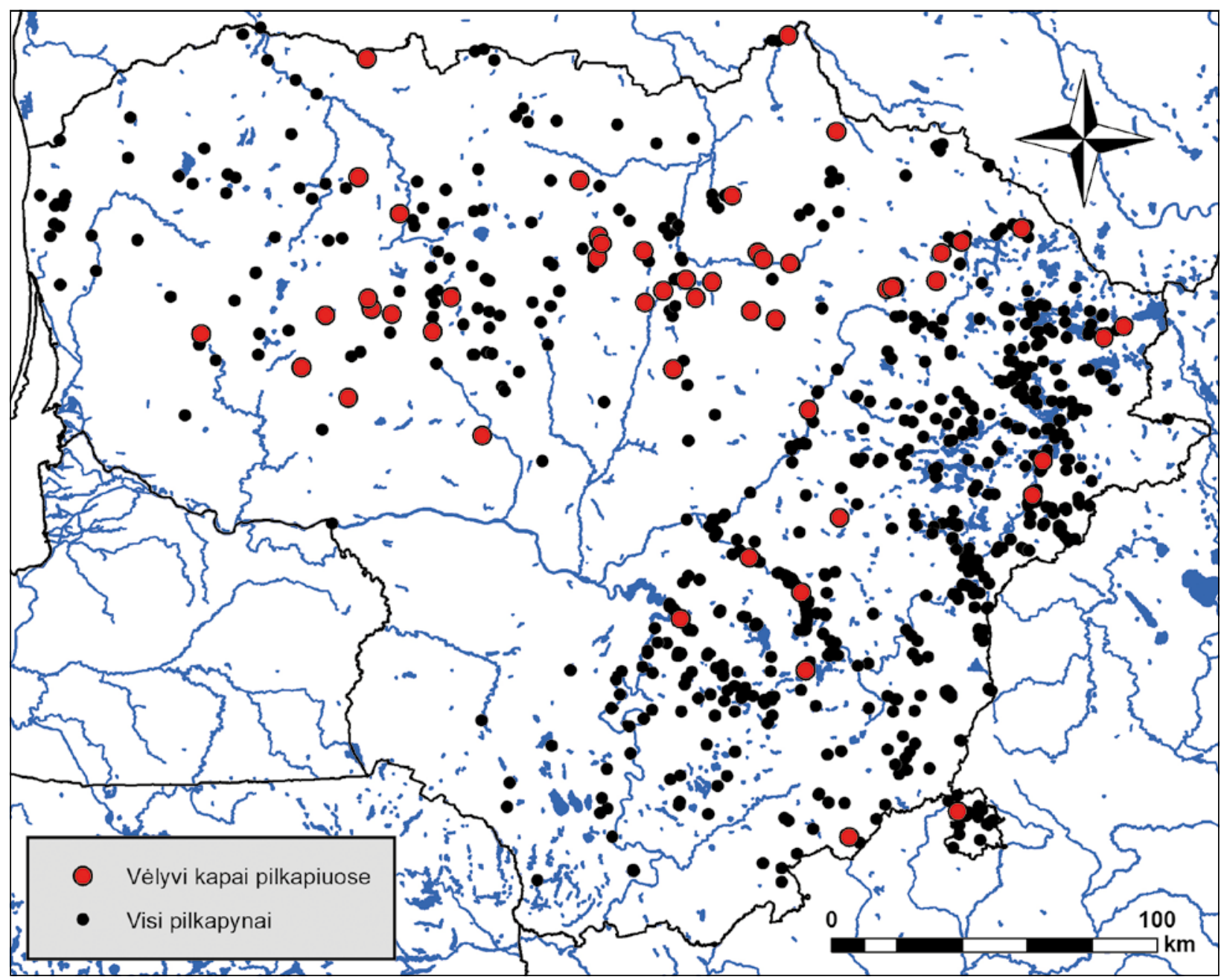

8 pav. Pilkapynai (pagal Lietuvos 1977; Kultūros 2019; Proligis 2019) ir pilkapynai, kuriuose rasta vèlyvujju viduramžiu - ankstyvųjų naujųjų laikų kapų. L. Kurilos bréž.

pagoniškuosius viduramžius, o išskirti kapus pilkapiuose, chronologiškai jau nutolusius nuo pilkapių tradicijos, ne visuomet yra paprasta. Tokių kapų aptikta ir aptartuose pilkapynuose (Paalksniuose, $\mathrm{Pa}$ juostyje, Maisiejūnuose-Surgantiškèse). Paprotys laidoti pilkapiuose Lietuvoje išsilaikè labai nevienodą laiką: Žemaitijoje ir Šiaurès Lietuvoje - iki I t-mečio vidurio (Michelbertas 2016, p. 301), Rytų Lietuvoje iki pirmųjų II t-mečio amžių (Kurila 2016, p. 203), o Šiaurès rytų Lietuvoje šimtmečius gyvavo daugiau pakartotinio laidojimo forma (Simniškytė 2013, p. 147). Todèl klausimas, ar konkretaus regiono kapai pilkapiuose laikytini tiesiog pakartotiniu laidojimu tose pačiose vietose po tam tikros pertraukos, ar grị̌imu prie senųjų, pamirštų protèvių laidojimo tradicijų, yra susijęs ir su kultūrinių kontaktų ir pačios pilkapių idejos sklaidos klausimu (pvz., ar Šiaurès Lietuvoje laidojimas pilkapiuose vèlyvajame geležies amžiuje buvo puikiai pažisstama, tačiau nepraktikuojama tradicija, o galbūt rytinių kaimynų laidojimo papročiai nebuvo žinomi?).

Ankstyviausi viduramžių kapai pilkapiuose, neabejotinai priklausantys jau pakartotinio laidojimo etapui, datuotini XIV a. pabaiga - XV a. Paalksniuose ištirtus 36-is kapus vèlyvaisiais viduramžiais padeda datuoti ne tik dirbinių tipologija, bet ir didelis bendras 
ikapių skaičius (17 - k. 17, 18 - k. 27, 22 - k. 29), tarp jų ir daug papildomų, ne kasdienio kostiumo dalių. Netiesiogiai jų ankstyvumą rodo nenusistovejjusi laidojimo kryptis ir monetų nebuvimas. Aiškiau viduramžiais (XIV a. pabaiga - XV/XVI a. sandūra) datuotini bent keli Visdergių-Papelkių pilkapyne aptikti kapai, pilk. 4 k. 2 Vigodkos-Dūkšto-Saksoniškių pilkapyne II.

Tačiau masiniu reiškiniu bent atskirose vietovėse laidojimas senuose pilkapiuose tapo jau XVIXVII a. Būtent šiuo laikotarpiu datuotinas vèlyvasis laidojimo etapas Pajuosčio, Plaučiškių, Riklikų, Akmenių, Kybartiškès pilkapynuose. Tikètina, kad istoriniais laikais masiškai laidota ir kituose Šiaurès Lietuvos pilkapynuose, tik to neatskleidžia nedidelès tyrimų apimtys juose. Dalyje pilkapynų laidota ir XVIII-XIX a., galbūt netgi iki XX a. pradžios, žinoma, šiame laikotarpyje vargu ar i pilkapius žvelgta kaip ị išskirtinius laidojimo erdvès komponentus.

Kai kurie pilkapynai laikui bėgant tapo būdingomis istorinių laikų kapinėmis, kuriose laidota visame plote, greičiausiai jau neskiriant pilkapių nuo tarpų tarp jų. Tik keliais atvejais ir tik kaip prielaidą galima mėginti apibrèžti vidinę kapinių raidą. Riklikų pilkapyne daugiausia kapų buvo didžiausiame pilk. VII, dydžiu (16-17 m skersmens ir 1,8 m aukščio) beveik prilygusiame būdingoms kai kurių ankstyvųjų naujųjų laikų senkapių kalvelėms (Tautavičius 1969, p. 43-52). Tikètina, kad tai - sampilas, kuriame vèlyvajame etape pradèta laidoti anksčiausiai. Tai patvirtina ir gausesnès, ịvairesnès nei kituose pilkapiuose bei ne vien kasdienio kostiumo dalimis laikytinos įkapès, pvz., k. 1 rasta pasaginè segè (Tautavičius 1969, p. 44), k. 12 - peilis, auskaras ir žiedas (Tautavičius 1969, p. 47), o k. 6 buvo net 5 i kapès: geležinè buožè, galąstuvas, odinè piniginè ir dvi geležinès sagtys (Tautavičius 1969, p. 45). Kaip minèta, kapų chronologija igalina manyti, kad Pajuosčio pilkapyne ankstyviausias iš ištirtų kapų (santykinio ankstyvumo indikatoriais laikytina pasaginè segè, įvijinė apyrankè) buvo didžiausiame pilk. IX (k. 28 (B)) (Michelbertas 2004, p. 10, 142). Visdergių-Papelkių pilkapyne laidojimo erdvè irgi greičiausiai plètèsi nuo pilkapių i jų aplinką. Akmenių pilkapyne galima izžvelgti bendrą laidojimo erdvès plètrą iš P (pilk. I, II) į Š (pilk. IV, V) pusę, apimančią laikotarpi nuo XV/XVI iki XIX/XX a. (Michelbertas 2006, p. 127-141, pav. 3).

Dar sunkiau įvertinti Paalksnių pilkapyno vèlyvojo etapo raidą. Nors įkapių kapuose aptikta gana daug ir jos gana tiksliai datuojamos, siaura visuminè jų chronologija neleidžia nustatyti kapinyno plètros modelio: nuo pilkapio i jo aplinką ar atvirkščiai, vienu metu visoje erdveje ar pan. Toje pačioje vietoje ( $\mathrm{i} \mathrm{R}$ nuo pilk. XXI) laidota ir vèlyvajame geležies amžiuje. Iš esmès visi griautiniai ir degintiniai šio laikotarpio kapai buvo suardyti. Daugelis dirbinių datuotini IX/X-XII/XIII a., tačiau kai kurių (skustuvų, skiltuvų, cilindrinių spynų, žąslų, žiedmarškès ir plokštelinių šarvų fragmentų, antkaklių, pasaginių ir apskritų plokštinių segių, žiedų, sagčių ir kt.) chronologija gali siekti ir XIV ar net XV a. (Michelbertas 2011, p. 84-157). Taigi vèlyvojo geležies amžiaus ir krikščioniškojo laikotarpio kapų atskyrimas gali būti tik formalios periodizacijos pasekmè, o iš tikrųjų šioje vietoje galejo būti nepertraukiamai laidojama nuo IX/X iki XV/XVI a. Bet kuriuo atveju tai, kad kapai i pilkapi ¡kasti būtent XV/XVI a., o ne anksčiau, yra dèmesio vertas faktas.

Nors daugelis kapų datuojami gana plačiais chronologiniais intervalais, be to, daugeliu atvejų trūksta duomenų apie laidojimą sampilų aplinkoje, galima teigti, kad kaip tik pilkapiai tapdavo pirmųjų kapų vietomis. Atrodo, pirmiausia būdavo laidojama didžiausiuose sampiluose, o kapinių plitimas ị kitus pilkapius ir „nulipimas“ nuo jų būdavo jau tolesnès raidos rezultatas. 


\section{LAIDOJIMAS PILKAPIUOSE IR LIETUVOS CHRISTIANIZACIJA}

Aptariamame laikotarpyje nebuvo supiltas nè vienas naujas pilkapis, taigi jokiu būdu negalima kalbèti apie pilkapių tradicijos atgimimą ar, juo labiau, jos tąsą. Laidojimas pilkapiuose buvo tiktai naujų savitų erdvių paieška šiaip visais kitais požiūriais ịprastiems palaidojimams. Kita vertus, galbūt būtent erdvėje slypejjo esminio kitoniškumo paieškos, lygiai kaip, pvz., kai kuriuose priešistorès laikotarpiuose ¡kapių dẻjimo ar kremacijos tradicijoms buvus norma, plokštinis kapinynas ar pilkapynas buvo pagrindinis skiriamasis bruožas.

Aptariamame laikotarpyje tikras žinias apie bent prieš 2-3 šimtmečius Rytų Lietuvoje ir maždaug prieš tūkstantmetị Šiaurès Lietuvoje apleistus pilkapynus turbūt jau buvo pakeitę padavimai ir mitologizuota žodiné tradicija - turima duomenų, kad XVI a. jie laikyti milžinų kapais (kapmilžiais) (Vaitkevičius 2014, p. 56). Pilkapiai, tikètina, sieti su kovų su kryžiuočiais laikotarpiu, galbūt net ir su vèlesniais įvykiais. Žodinè tradicija apie pilkapius gali atsirasti nepaprastai greitai: pvz., pirmieji jų vadinimo „prancūzkapiais“ atvejai užfiksuoti dar XIX a. pabaigoje (Покровскій 1893, p. 129-130), taigi nuo Didžiosios armijos įsiveržimo ši motyvą skiria vos 8 dešimtmečiai (3-4 žmonių kartos arba 2-3 dešimtmečiai nuo paskutinių ši karą gerai atsiminusių žmonių mirties). Dar svarbesni socialiniai, kultūriniai ir dvasinio gyvenimo pokyčiai, lydejję valstybès susikūrimą, ir krikščionybės ịvedimas. Taigi kas privertė didelès teritorijos gyventojus gana masiškai imti laidoti primirštuose ir pasakojimais apipintuose senovès pilkapynuose?

Vakarų Europoje pilkapių tradicijos sugrịžimas I t-mečio viduryje - 3-iajame ketvirtyje (Merovingų laikotarpyje žemyninèje dalyje ir Ankstyvajame anglosaksų laikotarpyje Britų salose) siejamas su vietos elito priešinimusi krikščionybès plètrai (Van de Noort 1993, plg. Crewe 2010, p. 44-46), siekiu, tapatinantis su protèviais, tikra ar tariama praeitimi, demonstruoti ir išlaikyti socialinį statusą kuriantis valstybėms, pretenzijas ị užimamas teritorijas (Williams 1998; 2006, p. 183).

Vèlesniais, krikščioniškaisiais, laikais požiūris i pilkapius keitèsi, juos pradèta laikyti netinkamų pagoniškų papročių atgyvena, laidoti pilkapiuose imta drausti, pvz., saksams skirtame Karolio Didžiojo VIII a. pabaigos kodekse Capitulatio de partibus Saxoniae (Effros 1997, p. 280-283), X a. bavarų teisès akte Decreta synodorum Bavaricarum (Monumenta 1863, p. 487). Ypač nuo Aukštųjų viduramžių senovės pilkapynai imti suvokti kaip pavojingos vietos - raganų, dvasių, kitų pagoniškų būtybių buveinès, juos imta niokoti (Roymans 1995, p. 9-17; Meurkens 2010, p. 22). Plečiantis parapijų tinklui, ịsivyravo laidojimas šventorių kapinėse, o senieji pilkapynai liko civilizacijos paliesto kraštovaizdžio užribyje. Slinktis nuo laidojimo pilkapiuose link jų baimès pastebima ir Viduriniajame-vèlyvajame anglosaksų laikotarpyje Britų salose (Semple 1998). Kai kur pilkapiai virto egzekucijų ir jų aukų laidojimo vietomis, kurios irgi buvo už kasdienio gyvenimo erdvès ribų (Reynolds 2009, p. 56-60, 178-179; Whyte 2003; Meurkens 2010). Jie galèjo igauti reikšmès ir administraciniame gyvenime - kaip susirinkimų vietos (Crewe 2010, p. 65-70; Semple, Williams 2015, p. 148).

XV-XVI a., kai ima plisti laidojimas senuose pilkapynuose, Lietuvos žemèvaldos sistema (bajorų žemèvalda ir baudžiava, pririšusi valstiečius prie žemès) bei socialinè sankloda verčia atmesti laidojimo pilkapiuose kaip socialinės konkurencijos ar pretenzijų ị teritorijas išraiškos modelị. Didžiajai visuomenès daliai tai nebebuvo aktualu, ypač $1447 \mathrm{~m}$. paskelbus Kazimiero privilegiją ir $1557 \mathrm{~m}$. j̇vykdžius Valakų reformą.

Krikščionybès sklaida, parapijų tinklo plètra XV a. Lietuvoje neprilygo šiems reiškiniams Vakarų Europoje. Nebuvo įsigalèjusi tradicija laidoti bažnyčių šventoriuose, o kapinių padètis kraštovaizdyje iš esmès nesiskyrè nuo senųjų pagoniškųjų kapinynų. 
Atsižvelgiant i daugumos aptariamų kapų chronologiją, galimybę laidojimo erdvių sugrąžinimą i pilkapynus sieti su reakcija i pačią christianizacijos pradžią reikètų vertinti skeptiškai. Galbūt lietuvių konservatyvumą ir nusistatymą prieš naujas laidojimo normas būtų galima įžvelgti platesniame paveiksle - daugelio priešistorinių laidojimo paminklų tąsoje istoriniais laikais. Tačiau intensyviausio laidojimo pilkapiuose laikotarpis nesutampa su pirmaisiais krikščionybės žingsniais Lietuvoje. Išskyrus Paalksnių pilkapyną ir kelis kitus kapus, daugelis jų datuotini vèlesniu laikotarpiu.

Iškart po Lietuvos krikšto stiprus visuomenès pasipriešinimas Bažnyčios primetamoms laidojimo normoms vargu ar tikètinas. Dar kone du šimtmečius pereiti prie krikščioniško laidojimo šventoriuose neleido ne tik senieji papročiai, bet ir retas, daugiau bajorijos ir miestiečių poreikius tenkinantis bažnyčių tinklas, dideles periferijos teritorijas paliekantis parapijų užribyje, dvasininkų ir apeigų gimtąja kalba trūkumas. Nesant stipraus reikalavimo keisti laidojimo papročius, nebuvo ir stipraus atoveiksmio, o laidosenos pokyčiai, pvz., laidojimo krypties vienodejjimas, buvo veikiau nuoseklios raidos, tik iš dalies veikiamos naujos religijos, rezultatas.

Atrodo, Bažnyčia Lietuvoje nebuvo išreiškusi griežtos ir aiškios neigiamos pozicijos dèl laidojimo pagoniškus laikus menančiuose kapinynuose ar pilkapynuose. Keliuose Livonijos ir Mažosios Lietuvos autochtonų senuosius papročius aprašančiuose šaltiniuose atsiskleidžia Bažnyčios nepasitenkinimas netinkamu mirusiųjų laidojimu ne šventoriuose, o „laukuose“ ar „miškuose“. Tiesa, šios vietos nesiejamos konkrečiai su pilkapiais ar pagoniškų laikų kapinynais, nors tai ir neatmestina. Pvz., tai akcentuojama $1428 \mathrm{~m}$. Rygos bažnytinès provincijos susirinkimo nutarimuose (Vèlius 1996, p. 616). Tokių žinučių kiek padaugèja per Reformaciją: Georgo Reiche’s 1549 m. Tilžès ir Kaukènų parapijų vizitacijoje (pagal Lukšaitė 1999, p. 183, išnaša 49), 1578 m. îsakuose Tilžès ir Ragainès apskričių bažnyčioms (Vèlius 2001, p. 231, 235), Pauliaus Einhorno „Latvių Kuršo kunigaikštystès reformavime“ (1636 m.) ir „Latvių tautos aprašyme“ (1649 m.) (Vèlius 2003, p. 618, 637) ir kituose dokumentuose (Vèlius 2003, p. 649-650, 657, 673-675). Sambijos vyskupo Michaelio Junge's įsake (1426 m.?) prūsams draudžiama atlikti pagoniškas (mirusiųjų minejjimo?) apeigas greta pilkapių (lot. tumulos) ir kapų (Vèlius 1996, p. 482, 484), nors čia ir nekalbama apie laidojimą šiose vietose.

Laidojimą netinkamose vietose pastebejo ir katalikų Bažnyčia (Baronas ir kt. 2006, p. 208). 1737 m. Žemaičių vyskupas Mykolas Karpis ganytojiškame laiške Žemaičių vyskupijos dvasininkams ne tik atkreipè dèmesi $\mathfrak{i}$ tokius papročius, bet ir nurode jų priežastị: „...toks netikęs laidojimas laukuose ir kitose nešventintose vietose, kaip manoma, paplito dèl plèšikišku mokesčiu, kai klebonai daugiau negu leidžiama išreikalauja, net išspaudžia iš savo parapijiečiu už laidojima...." (Vèlius 2005, p. 129-130). Tačiau greta kitų šaltiniuose ir Bažnyčios dokumentuose aprašomų „pagoniškų paklydimų“ - stabų ir senųjų dievybių garbinimo, prietarų, būrimų, aukojimo apeigų, šv. Mišių nelankymo, sakramentų nepriemimo, palaido gyvenimo ir kt. - laidojimo vietų pasirinkimui teikta palyginti nedaug reikšmès. Didesne blogybe laikyta ne netinkama vieta, o deramų apeigų nesilaikymas. Laidojimas laukų kapinaitėse Lietuvoje taip niekada ir neišnyko, o Bažnyčiai teko su tuo susitaikyti.

Bažnyčių tinklo tankèjimas, išaugęs dèmesys krikščionybès sklaidai tarp valstiečių jų kalba susiję su Reformacija, kai Lietuvoje kūrèsi evangelikų liuteronų ir reformatų bei kitų konfesinių grupių (Mažoji Bažnyčia, Lietuvos broliai) bažnyčios, bei ypač su Kontrreformacija ir jèzuitų veikla. Žemaičių vyskupijoje bažnyčių skaičius nuo 19-os 1500 m. išaugo iki 51-os 1613 m., nors vienai bažnyčiai tenkantis plotas vis vien liko daug didesnis nei Lenkijoje (Błaszczyk 1993, p. 193-195). Dalis anksčiau evangelikų perimtų bažnyčių XVII a. pradžioje vèl atiteko katalikams. XVII a. 1-ajame trečdalyje vidutinis 
parapijos spindulys peržengè kritine laikytiną $10 \mathrm{~km}$ ribą, nebepaliekančią "pagoniškų anklavų“ (Bumblauskas 2015, p. 11). Naujos parapijos buvo nuolat steigiamos ir Vilniaus vyskupijoje. Žinoma, ir tuomet šiame tinkle liko daug spragų, o šaltiniuose tebeminimi bažnyčių nelankantys ir senųjų apeigų tebesilaikantys kaimai bei daugybè pagonybès reliktų. Tačiau XVI-XVII a. sustiprèjęs spaudimas atsisakyti senųjų papročių galbūt lèmè ir padidejjusị pasipriešinimą jam. Čia galima prisiminti ir kitą minètą veiksnị, atbaidantị žmones nuo laidojimo deramose vietose - bažnyčios tarnų lupikavimą (Baronas ir kt. 2006, p. 208) - dèl to, pvz., 1579 m. vizitatoriams skundèsi ir Varnių miestiečiai (Jovaiša 1998, p. 271, 273).

Kita vertus, pastarojo meto istorikų darbuose pabrèžiama gana sparti ir sèkminga Lietuvos christianizacija (Baronas, Rowell 2015), todèl tiek laidojime, tiek kitose gyvenimo srityse išlaikyti papročiai turbūt laikytini ne pagonybe kaip ideologine visuma, o veikiau jos rudimentais - savotiška „buitine pagonybe“, arba, Bažnyčios požiūriu, prietarais. Vargu ar pagoniškų tradicijų tęstinumas laidojant rodo priešiškumą apskritai Lietuvos evangelizacijai. Tai greičiau papročių inercija, nepriimant konkrečių ritualinių naujovių, ypač tų, kurios buvo susijusios su papildomomis išlaidomis.

Pažymètina, kad iš esmès visi nagrinèjami pilkapynai nepatenka ị ankstyviausių (iki $1500 \mathrm{~m}$.) bažnyčių artimiausią lauką (10 km spinduliu) arba yra jo paribiuose. Bažnyčios arčiau daugelio jų (prie Druskių, Noruišių, Pamarnakio, Pašilių, Riklikų, Skverbų, Visėtiškių ir kt.) atsiranda XVI a. arba XVII a. 1-ojoje pusèje (prie Kybartiškès, Paragaudžio ir kt.), bet dalis pilkapynų vis dar lieka toliau nei už $10 \mathrm{~km}$ tiesia linija nuo jų (Berklainiai, Lygalaukiai, Pajuostis (Miežiškių sen.), Pakalniškiai, Raginėnai, Visdergiai-Papelkiai) (9 pav.).

Taigi lietuvių vengimą laidoti, laikantis krikščioniškų normų, galima aiškinti dviem iš pirmo žvilgsnio priešingomis, bet iš tiesų viena kitai neprieštaraujančiomis priežastimis. Viena vertus, arti nesant bažnyčių, nebuvo nei galimybės laidoti šventoriuje, nei paprasčiausių žinių apie krikščioniškas laidotuves. Kita vertus, XVI-XVII a. bažnyčioms priartèjus prie žmonių, dvasininkų îkyrumas, verčiant prie naujo tikejjimo ir ritualinès praktikos, raginimas nustoti laidoti „laukuose ir miškuose“ ir godumas galèjo lemti priešingą rezultatą - dar atokesnių laidojimo vietų paieškas. Ko gero, atsirandant spaudimui susirasti naujas laidojimo vietas, vienos bendruomenès kūrè naujus kapinynus, o kitos, kurių gyvenamojoje erdvejje buvo senų pilkapynų ir kurios buvo geriau išlaikiusios atmintị apie protèvių kapus, atsigręžè i juos. Galbūt tam ịtakos turèjo ir išskirtinè pilkapynų išvaizda, kuri derejo su perejjimo ì pomirtini gyvenimą kaip lipimo ị kalną samprata (žr. Beresnevičius 1990, p. 132-138). Nors čia nebūtinai esama tiesioginio ryšio su laidojimu pilkapiuose, pažymètina, kad daugelis to meto senkapių taip pat yra kalvelèse; kai kurių forma primena didelius sampilus.

Analogiškai ịvertinus erdvinị evangelikų bažnyčių bei koplyčių ir aptariamų pilkapynų santykí, ryšio tarp jų nepastebèta (10 pav.). Matyt, liuteronai ir reformatai, pirmieji atkreipę dèmesi i x pagoniškų papročių praktikavimo mastą, gyventojams buvo priimtinesni bent ta prasme, kad neiššaukè demonstratyvaus pasipriešinimo sugrịžtant ị pagoniškąsias laidojimo vietas. Kapus pilkapiuose laikant pasipriešinimo primetamoms naujoms krikščioniškoms apeigoms išraiška, pirmiausia jie sietini su nepalankumu katalikų Bažnyčios veiklai. Žinoma, suabsoliutinti per Kontrreformaciją suintensyvejusios katalikybès sklaidos įtakos laidojimo pilkapiuose atnaujinimui irgi nereikètų. Matyt, paprastam žmogui, gyvenančiam cuius regio, eius religio sąlygomis, ir nebuvo didelio skirtumo, kas konkrečiai ji verčia keisti gyvenimo būdą. Apskritai laidojimas pilkapiuose kaip priešprieša Bažnyčios spaudimui laikytina tik modeliu, kuriam konkrečiais atvejais empirinè medžiaga gali ir prieštarauti. Pvz., kai kuriuose kapuose aptikta kryželių, medalèlių, žiedų su „IHS“ monograma, o Pajuosčio pilk. VI k. 24 (C) rastas 


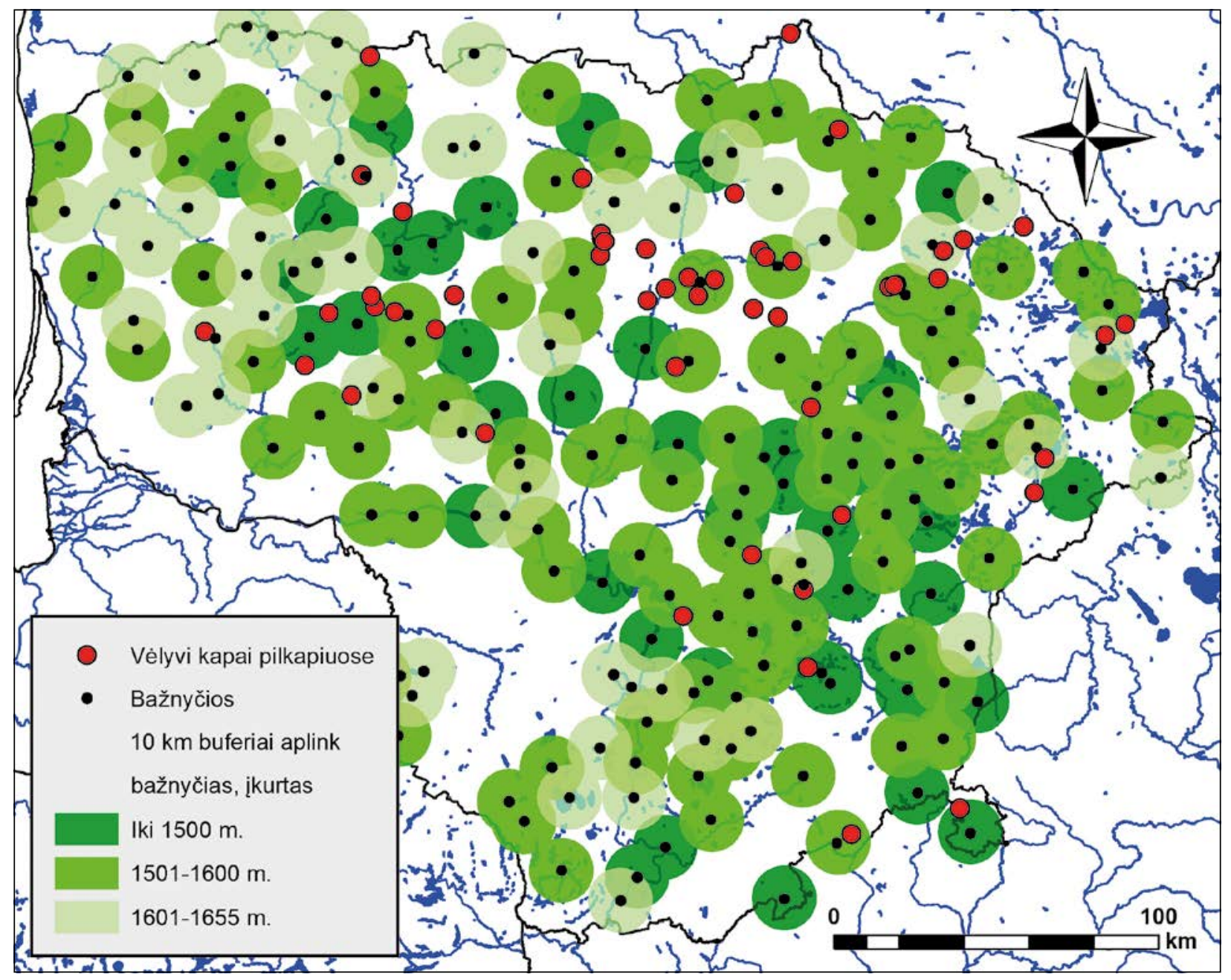

9 pav. Vilniaus ir Žemaičių vyskupijų katalikų bažnyčių tinklas iki XVII a. vidurio (pagal Ochmański 1972; Codex 1984; 1989; Błaszczyk 1993; Jučas 2007, p. 52-66) bei $10 \mathrm{~km}$ spindulio buferiai aplink jas ir geležies amžiaus pilkapynai, kuriuose rasta vèlyvụjų viduramžių - ankstyvųjų naujųjų laikų kapų. L. Kurilos brěż. ${ }^{1}$

medalèlis su jèzuitų ordino ịkūrèjo šv. Ignaco Lojolos ir jèzuito misionieriaus šv. Pranciškaus Ksavero atvaizdais lyg ir rodo, kad palaidotasis prieš katalikybę tikrai nebuvo nusistatęs. Tačiau šie kapai datuotini XVII-XVIII a., kai katalikybė jau buvo atgavusi vyraujančias pozicijas, pilkapynai jau virto krikščioniškomis kapinėmis, ir atmintis apie pagonišką jų kilmę nyko.
Mįslę užmena ir Akmenių pilk. I k. 3 rastas gintarinis signetinis žiedas su „Aksak“ herbu. Šio seno (kovų su totoriais laikų, XIV a.?) lietuviškos kilmès (lenk. Obrona, liet. apsauga?) (Niesiecki 1839, p. 15-17) herbo turètojai Žemaitijoje neaiškūs (žr. Michelbertas 2006, p. 123). Taip pat neaišku, ar dalis kilmingųjų (jei žiedą laikysime luomo ženklu, o ne patekusiu ị kapą kitu būdu) irgi galèjo

${ }^{1}$ Kai kurių bažnyčių ịkūrimo metai nurodomuose šaltiniuose pateikiami nevienodai, remiantis skirtingais dokumenais: fundacijomis ar kitais bažnyčių buvimą nurodančių aktais (renovacijomis, dotacijomis). Be to, kai kurios bažnyčios veikẻ su pertraukomis, priklausė ir kitoms konfesijoms. Todèl čia pateikiami tik apytiksliai jų ịkūrimo meto intervalai. 


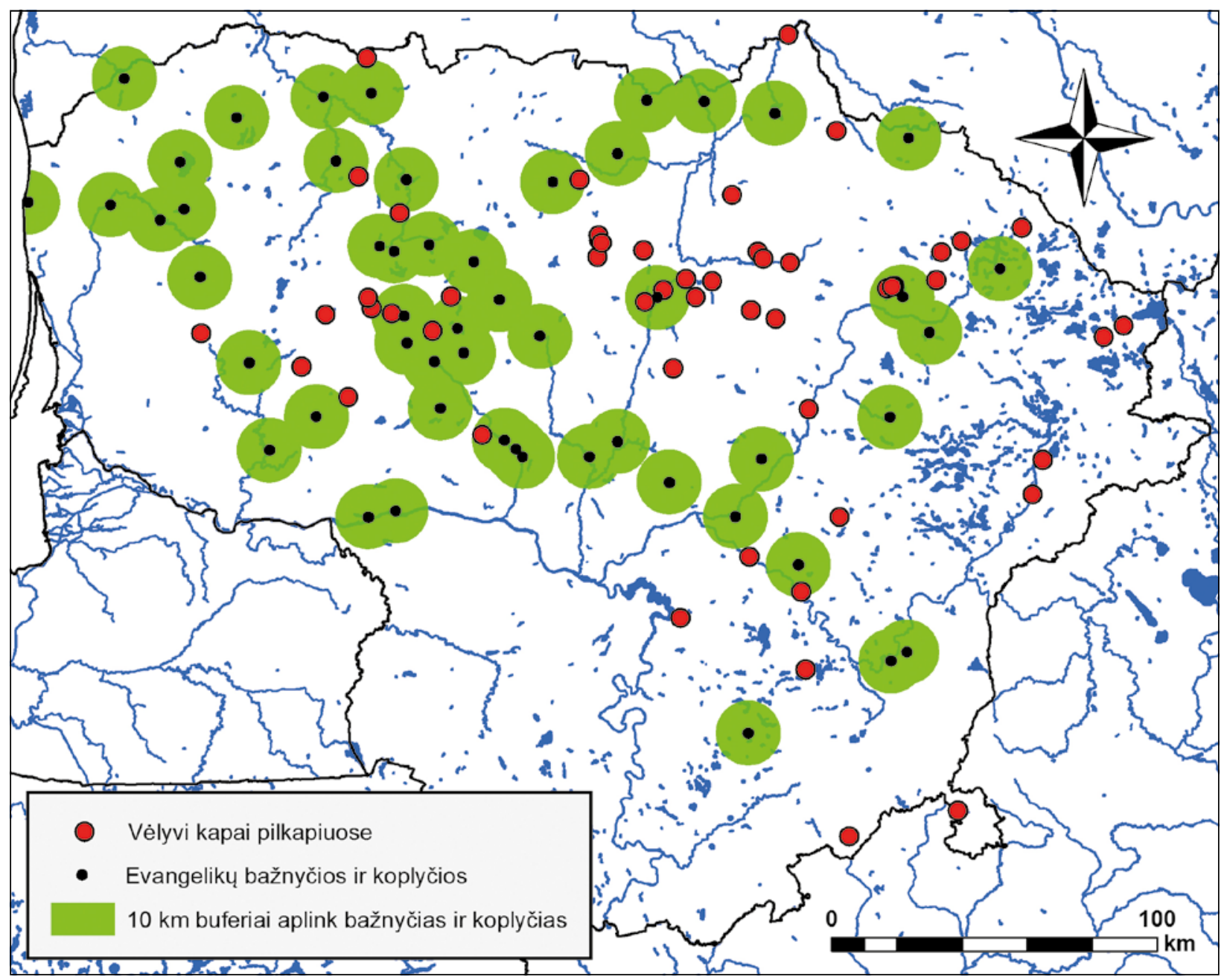

10 pav. Evangelikų bažnyčių ir koplyčių tinklas XVI a. - XVII a. pradžioje Vilniaus ir Žemaičių vyskupijų teritorijoje (pagal Lukšaitė 1999, lent. 3, 4; Vaivada 2004, p. 148-150) bei $10 \mathrm{~km}$ spindulio buferiai aplink jas ir geležies amžiaus pilkapynai, kuriuose rasta vèlyvųjų viduramžių - ankstyvųjų naujųjų laikų kapų. L. Kurilos brèž.

būti nepatenkinti Bažnyčios primetamų naujovių sklaida, ar pačia religine nesantaika. Galbūt grịžimas ị pagoniškas laidojimo vietas atskleidžia ir savotišką žmonių sutrikimą konfesijų ịvairovės, religinių nesutarimų bei dažnų konversijų fone. Visa tai paprasto žmogaus akyse greičiausiai menkino krikščionybės autoritetą, o skirtingos dogmos ją darè dar mažiau suprantamą ir nepriimtiną. Baltarusijoje aptikti vèlyvi kapai pilkapiuose kartais irgi aiškinami būtent atsigręžimu ì pagonybę kaip protestu prieš krikščionybès krypčių ịvairovę (Дучыц 1997, p. 78).
I klausimą, kodèl pilkapynų gausioje Rytų Lietuvoje istoriniais laikais nebuvo paplitusi laidojimo senuose pilkapiuose praktika, atsakyti sunku. Galbūt tam ịtakos turëjo ankstyvesnè (dar XIII a.) pažintis su krikščionybe, galbūt - Rytų slavų kaimynystè ir jos lemtas didesnis religinis pakantumas, galbūt - tiesiog atrastos kitos pagoniškumą demonstruojančios kultūros formos. Neatmestini ir baltų mentaliteto skirtumai, lèmę nevienodą religinị konservatyvumą, kuriuos iliustruoja nežinomo autoriaus „Pasaulio aprašymo“ (1255-1260 m.) eilutès: „Rytuose yra pagoniu žemè, kuri vadinasi Žemaitija. Niekas čia 
neskelbė Dievo žodžio be kalavijo. [...] Minètieji lietuviai, jotvingiai ir nalšènai yra lengvai pakrikštijami, kadangi nuo pat vystyklu yra auklejjami krikščioniu aukliü“ (Vèlius 1996, p. 246).

\section{„KITOKIE“ KAPAI}

Kai kurie iš aptariamų kapų priskirtini „kitokios laidosenos“ atvejams, tikètina, susijusiems su savitu statusu ar mirties aplinkybėmis. Lygalaukių ir Didžiulių (4 pav.) pilkapynuose aptikti palaikai, sprendžiant iš jų padèties duobèse, netgi nelaikytini kapais - tai veikiau tiesiog skubotas kūnų užkasimas. Dèl šautinių žaizdų Muoriškių ir Druskių pilkapynuose aptiktus palaikus reikia sieti su smurtu. Maisiejūnuose tikètinai palaidotos vienalaikès mirties (smurto ar epidemijos?) aukos. Visi šie kapai buvo be ikapių, tiksliau nedatuoti, todèl gali būti ir vèlyvesni už aptartus anksčiau. Kodèl kūnai buvo užkasti būtent pilkapiuose, neaišku, ir vargu ar čia reikètų ieškoti bendro vardiklio. Galbūt pilkapiai laidojimui pasirinkti dèl jų atokumo, išsaugotos, bet jau galutinai transformuotos atminties, juos siejant jau su priešų kareivių kapais ar piktosiomis dvasiomis.

Keli nebūdingos konstrukcijos kapai aptikti ir kituose pilkapynuose. Akmenių pilk. III k. 30 (20) (Michelbertas 2006, p. 138) ir Riklikų pilk. VIII k. 2 (Tautavičius 1969, p. 59) buvo užversti akmenimis, o Paalksnių pilk. XXI k. 8 po akmenị gulèjo ant blauzdų (Michelbertas 2011, p. 167). Savotiškai „tipiškoje“ netradicinèje padètyje (žr. Vèlius 2010, p. 71-72), suriesti, buvo palaidoti individas Riklikų pilk. VII k. 10 (Tautavičius 1969, p. 46-47) ir vienas asmuo Raginènuose, o kitas pastarajame pilkapyne palaidotas asmuo gulëjo ne horizontaliai, o galva žemiau kojų (Simniškytè 2011, p. 198).

Kuris iš literatūroje dažniausiai siūlomų „kitoniškumo“ aiškinimų šiais atvejais atrodytų ittikinamiausias, ar šis „kitoniškumas“ sietinas kaip tik su laidojimu pilkapiuose ir ar, ieškant tokių sąsajų, apskritai nèra rizikos ieškoti priežasčių ir dėsningumų ten, kur jų nèra, sunku pasakyti. Galbūt tai buvo nusikaltimų ar egzekucijų aukos, bendruomenės nepagarbą užsitraukę asmenys, atstumtieji, baimę keliantys „vilkolakiai“ ar „prisikèlę numirèliai“. Tačiau, ieškant aiškesnių atsakymų, būtų reikalingi išsamesni tyrimai, apimantys visų vienalaikių kapinynų duomenis.

\section{IŠVADOS}

Surinkti duomenys apie 400-us vèlyvų kapų iš 26-ių pilkapynų ir informacija apie dar 25-iuose pilkapynuose galimai buvusius tokius kapus leidžia teigti, kad vèlyvaisiais viduramžiais ir ankstyvaisiais naujaisiais laikais mirusiųjų laidojimas senuose pilkapiuose buvo ne pavieniai išskirtiniai atvejai, o gana plačiai praktikuotas paprotys. Didelè chronologinè distancija nuo pilkapių, kultūriniai ir religijos pokyčiai verčia ši fenomeną aiškiai skirti nuo priešistorèje nereto laidojimo su pertraukomis ir grịžimo i ankstesnes laidojimo vietas. Istoriniais laikais nebuvo pilami nauji pilkapiai, taigi pakartotinio laidojimo negalima laikyti tikru pilkapių tradicijos atgimimu.

Išskyrus neịprastą laidojimo vietą, didžioji dalis kapų niekuo neišsiskiria iš istorinių laikų senkapių. Laidoti ịvairaus amžiaus abiejų lyčių asmenys, dažniausiai krikščionišku papročiu guldyti galva i $\mathrm{V}$ ar artima kryptimi. Kapuose aptikta laikotarpiui būdingų ịkapių: ankstyvesniuose daugiau pridètinių įkapių, vėlesniuose - aprangos detalių, smulkių papuošalų, monetų.

Istorinių laikų kapu pilkapiuose aptikta beveik visoje Lietuvos teritorijoje, kurioje viename ar kitame geležies amžiaus laikotarpyje laidota pilkapiuose. Vis dèlto pagrindinis šio papročio sklaidos arealas yra Žemaitija ir Šiaurès Lietuva (teritorija tarp Šventosios ir Jūros aukštupio, V ir P pusèje natūraliai apibrèžiamas senojo geležies amžiaus Žemaitijos ir Šiaurès Lietuvos pilkapių paplitimo ribų, o Š pusèje nusidriekianti į Latviją). Ankstyviausi 
tokie kapai datuotini viduramžių pabaiga (XIV a. pabaiga - XV a.), tačiau masiniu reiškiniu laidojimas senuose pilkapiuose tapo XVI-XVII a. Kai kurie pilkapynai ilgainiui tapo ištisomis kaimų kapinèmis, kuriose laidota iki pat XVIII-XIX a. ar net $\mathrm{XX}$ a. pradžioje.

Laidojimo vietų grižimas ị senuosius pilkapynus Europos kontekste nèra unikalus. XV-XVI a. Lietuvos žemèvaldos sistema ir socialinė sankloda verčia atmesti laidojimo pilkapiuose kaip socialinès konkurencijos ar pretenziju i teritorijas išraiškos modelį. Šis reiškinys veikiau sietinas su Lietuvos christianizacija. Viena vertus, iki XVI a. Lietuvoje esant labai retam bažnyčiu tinklui, trūkstant kunigų ir krikščionybès sklaidos gimtąja kalba, neįsitvirtino laidojimas bažnyčių šventoriuose ir krikščioniškos apeigos. Keliuose šaltiniuose yra minimas laidojimas „laukuose ir miškuose“; tai gali reikšti ir pilkapynus. Kita vertus, ankstyvajame Lietuvos christianizacijos etape nebuvo didelio Bažnyčios spaudimo keisti laidojimo papročius, kuris būtų galèjęs sukelti gyventojų priešinimąsi. Didesnè konfrontacija tarp Bažnyčios mokymo ir gyventojų konservatyvumo atsirado Reformacijos ir ypač Kontrreformacijos metu, kai ir daugèjo bažnyčių, ir sustiprejo dèmesys gyventojų evangelizacijai bei krikščioniškųjų ritualų laikymuisi. Tai, taip pat šaltiniuose minimi lupikiški mokesčiai už krikščioniškas laidojimo apeigas galëjo turèti priešingą poveikị - versti kapinynams ieškoti dar nuošalesnių vietų, o dalį bendruomenių atsigręžti i senuosius pilkapynus kaip i pagoniškosios praeities simbolius. Galbūt grižimas ị pagoniškas laidojimo vietas rodo ir savotišką žmonių sutrikimą ir menką krikščionybès autoritetą konfesijų ir dogmų îvairoves, religinès nesantaikos bei dažnų konversijų fone.

Keli i pilkapius ikasti kapai, kuriuose individai buvo nepagarbiai įmesti ị duobes, užversti akmenimis, paguldyti ant šono, yra priskirtini "kitokiu““ kapų kategorijai. Kai kurie jų tikètinai datuotini dar vèlesniu laikotarpiu už aptariamuosius straipsnyje. Tai gali būti nusikaltimų ar egzekucijų aukos, bendruomenès nepagarbą užsitraukę asmenys, atstumtieji, baimę keliantys „vilkolakiai“ ar „prisikèlę numirèliai“.

\section{Padèka}

Dékoju dr. Eugenijui Svetikui (Lietuvos istorijos institutas) už konsultacijas rengiant ši straipsnị. 


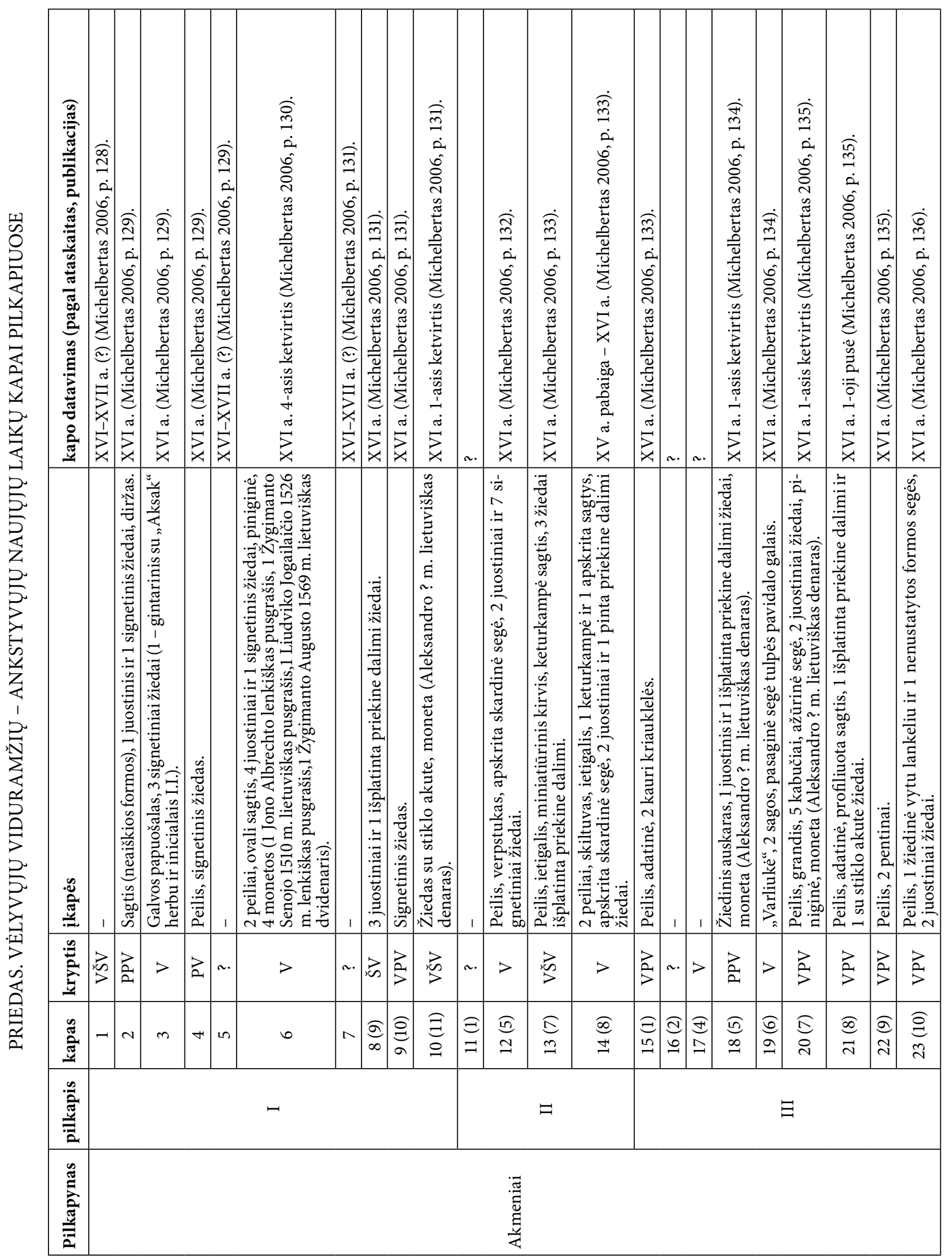




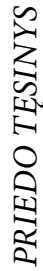

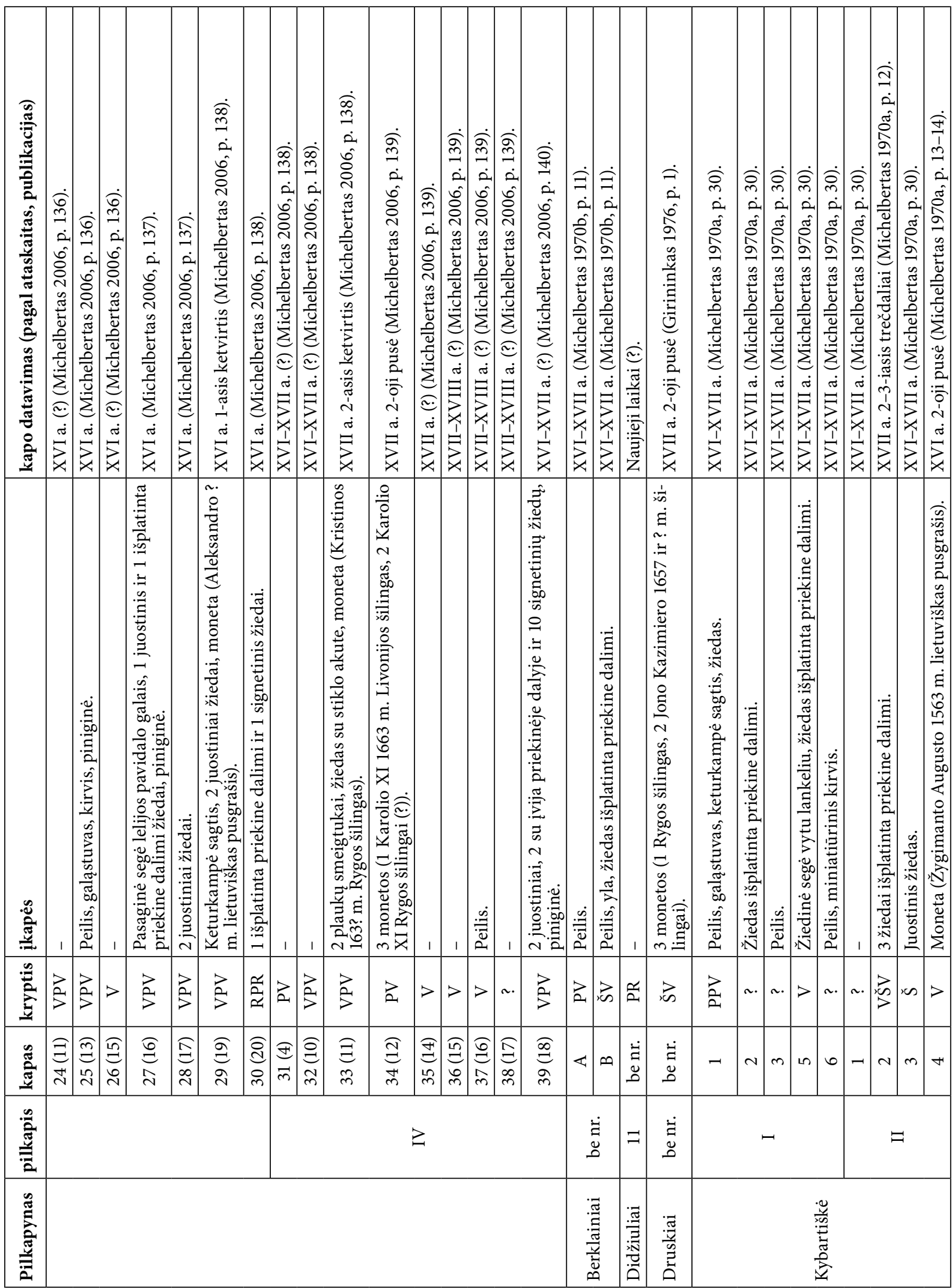


2
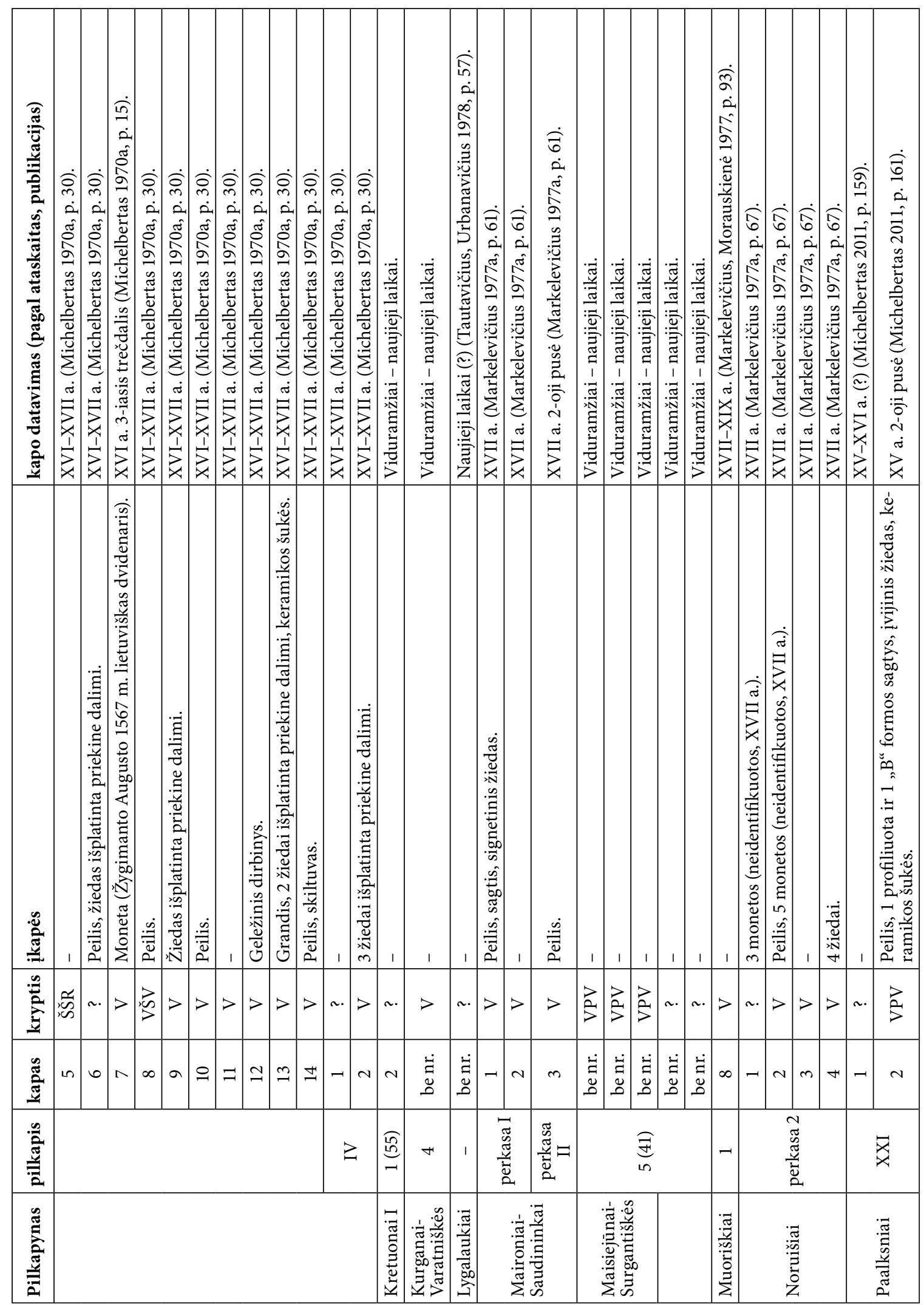


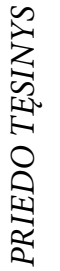

\begin{tabular}{|c|c|c|c|c|c|c|c|c|c|c|c|c|c|c|c|c|c|c|c|c|c|}
\hline 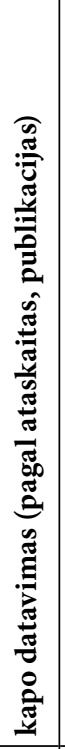 & 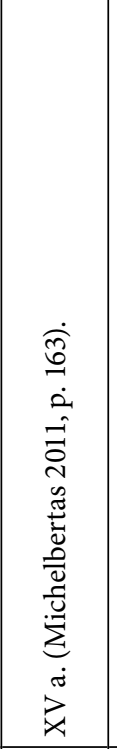 & 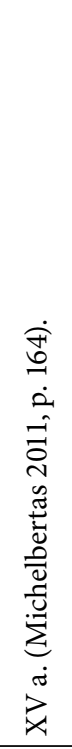 & 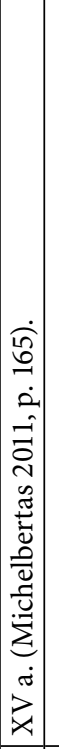 & 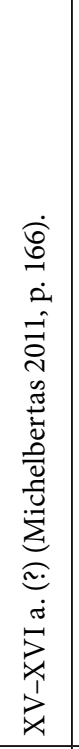 & 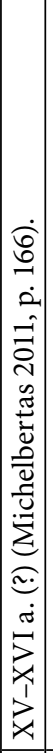 & 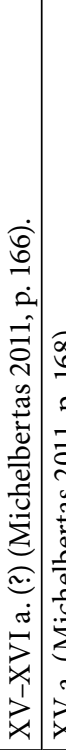 & 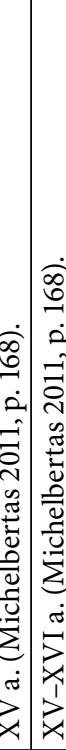 & 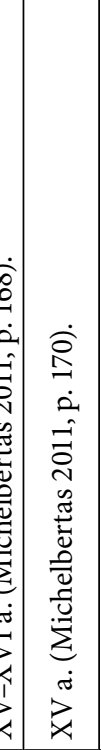 & 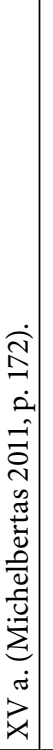 & 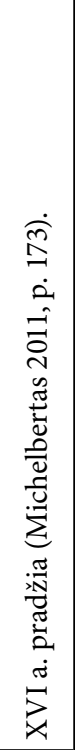 & 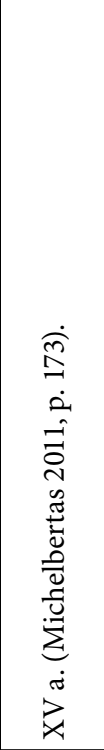 & 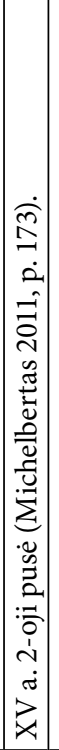 & 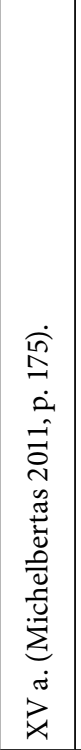 & 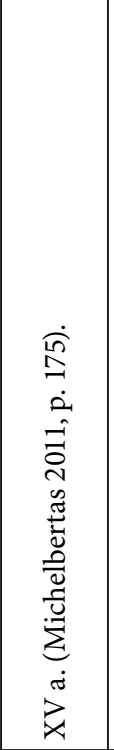 & 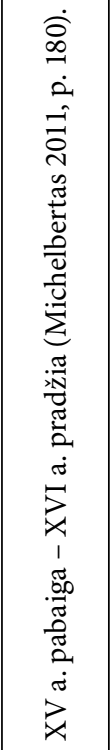 & 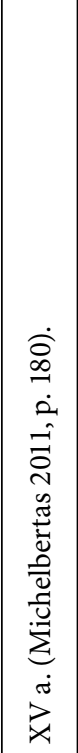 & 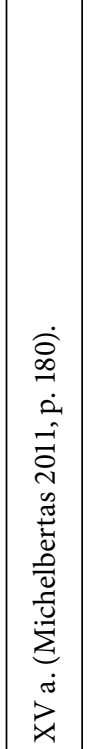 & 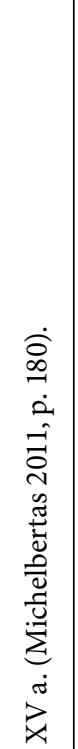 & 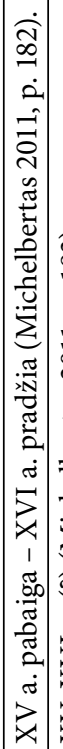 & 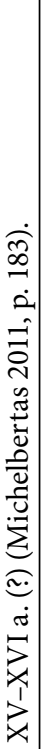 & 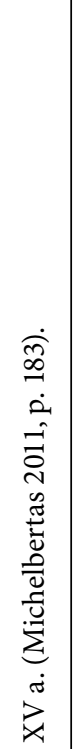 \\
\hline 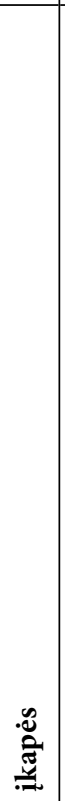 & 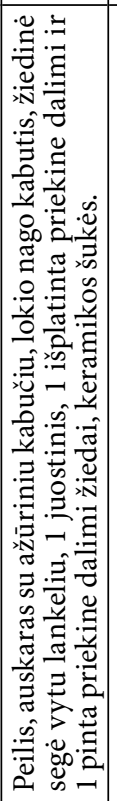 & 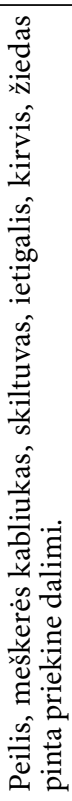 & 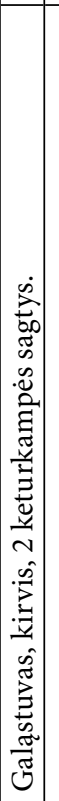 & 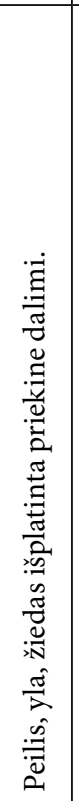 & 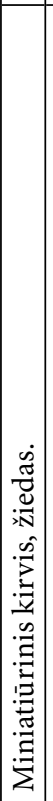 & & 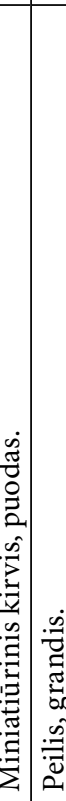 & 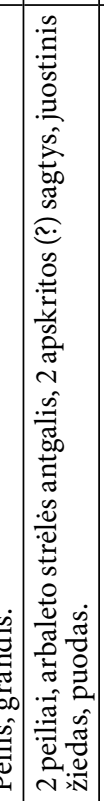 & 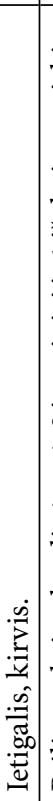 & 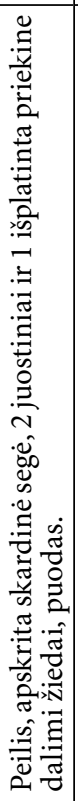 & 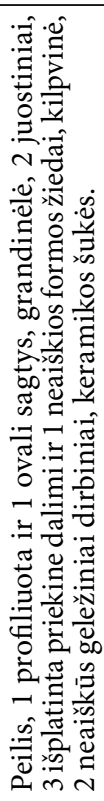 & 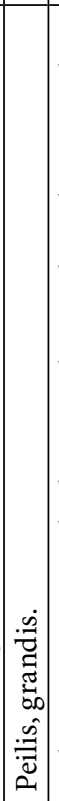 & 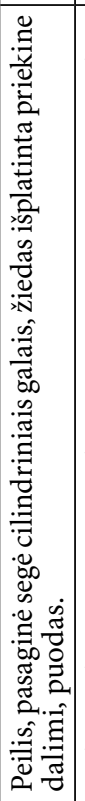 & 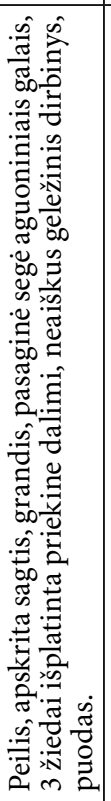 & 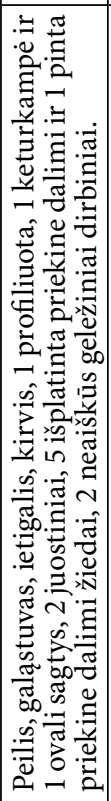 & 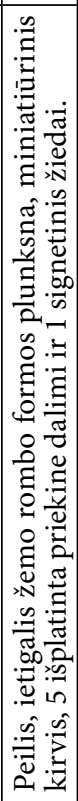 & 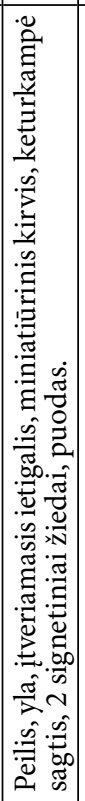 & 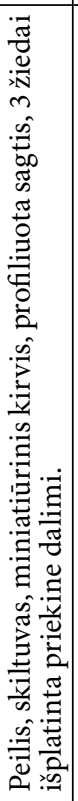 & . & 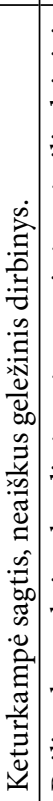 & 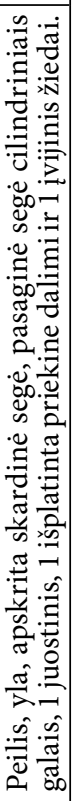 \\
\hline 产 & $\stackrel{\vec{a}}{>}$ & 约 & a & $\sim$. & $\begin{array}{l}\underset{\sim}{\approx} \\
\widetilde{\sim}\end{array}$ & is is & $\tilde{s} \mid$ in & 呑 & $\sim$. & 点 & in & $\begin{array}{l}3 \\
i \\
>\end{array}$ & $\simeq$ & 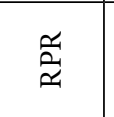 & $\simeq$ & $\simeq$ & 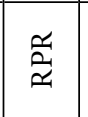 & in & $\sim$. & $\sim$ & $\sim$. \\
\hline 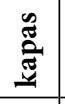 & $m$ & 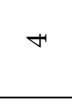 & 10 & 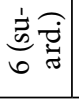 & 0 & $\wedge$ & $\infty$ & 은 & $\exists$ & $\approx$ & 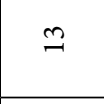 & $\Xi$ & $\stackrel{2}{\sim}$ & 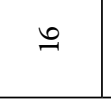 & $\therefore$ & $\stackrel{\infty}{\sim}$ & 2 & ㄱ. & $\vec{\sim}$ & $\approx$ & $\tilde{\sim}$ \\
\hline 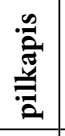 & & & & & & & & & & & \multicolumn{8}{|c|}{ 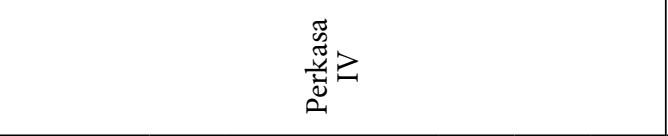 } & \multicolumn{3}{|c|}{ 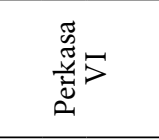 } \\
\hline 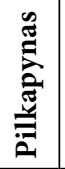 & & & & & & & & & & & & & & & & & & & & & \\
\hline
\end{tabular}




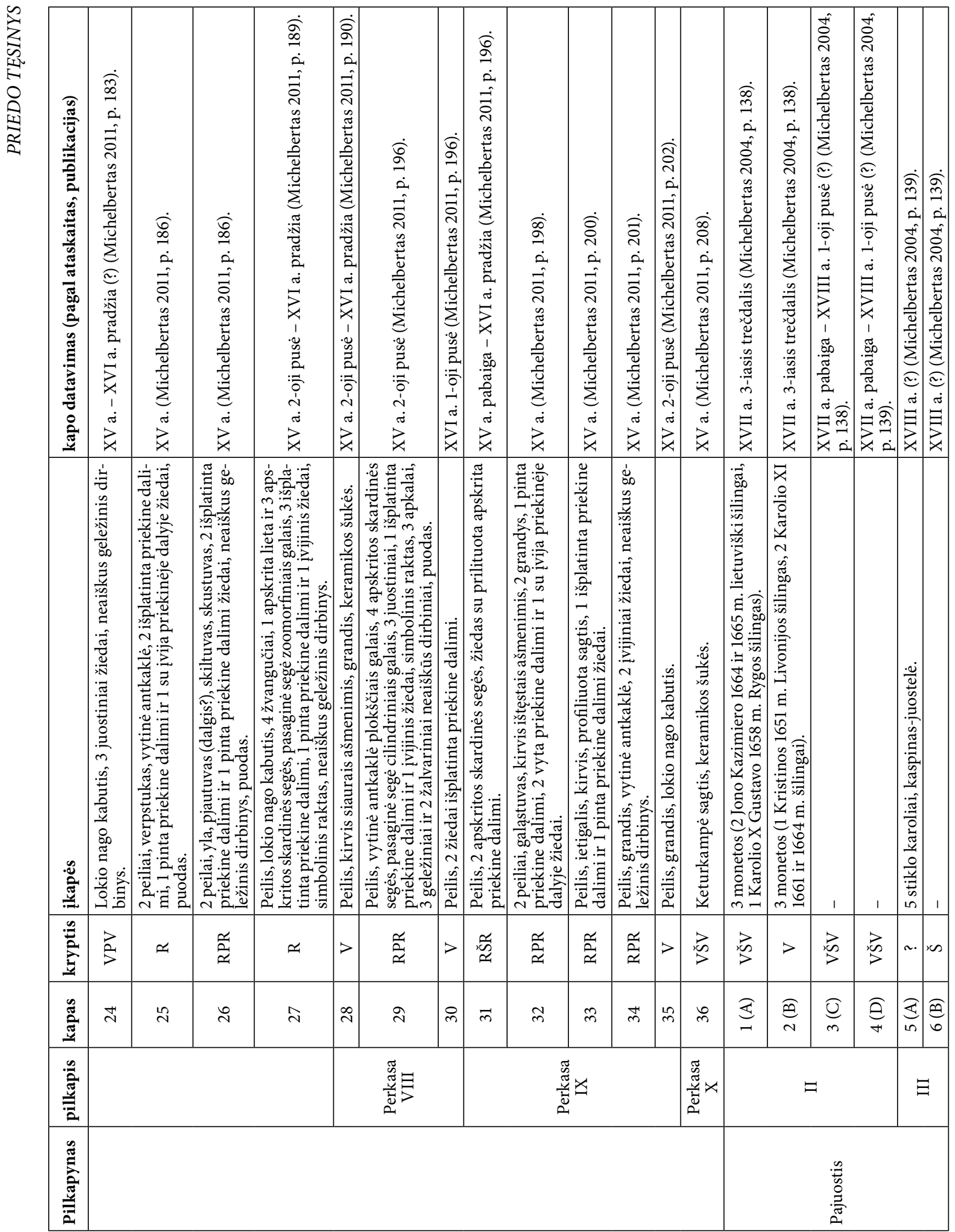




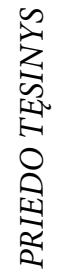
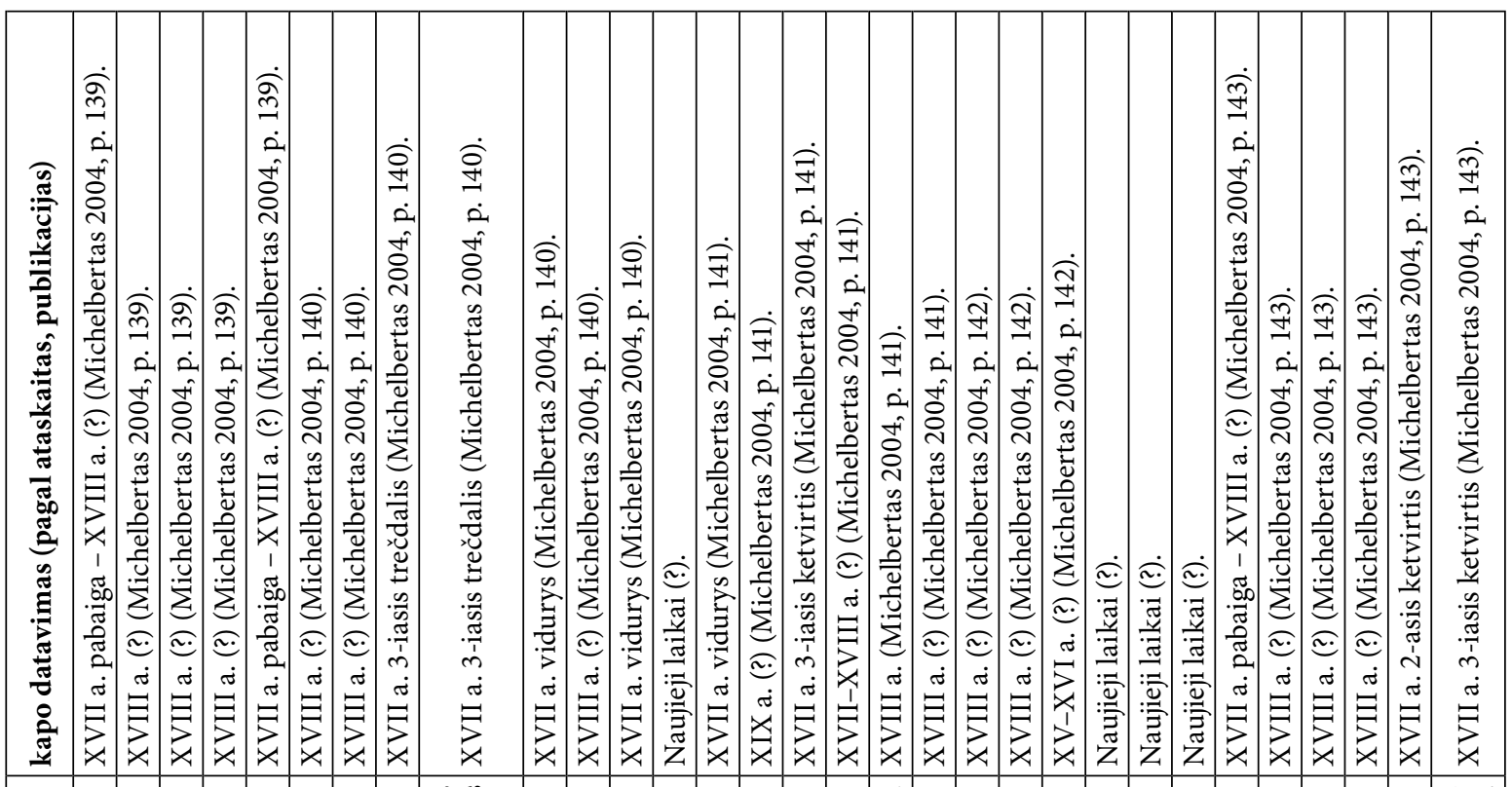

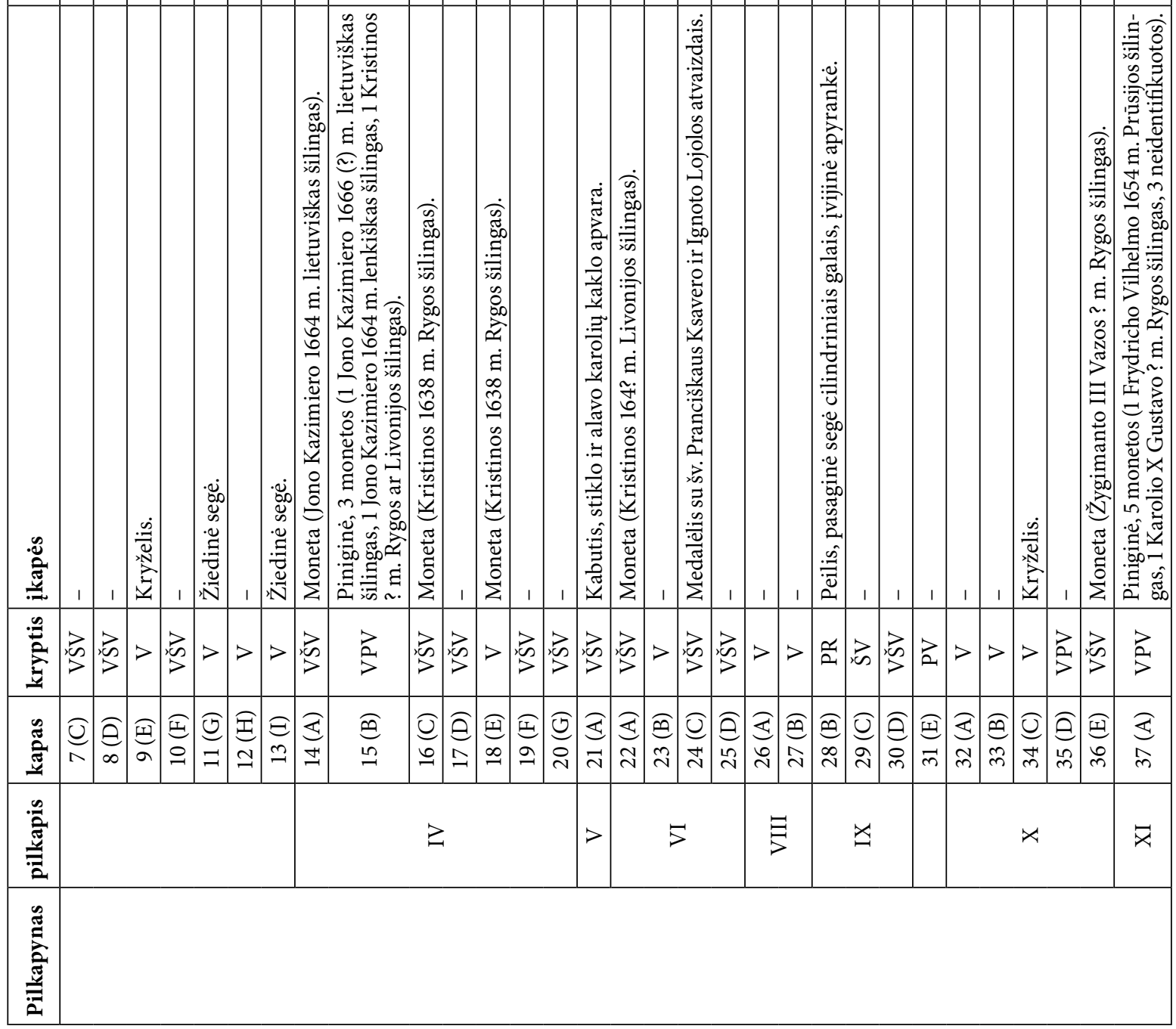


2
3
0
0
0
0
0
0
2
2
2

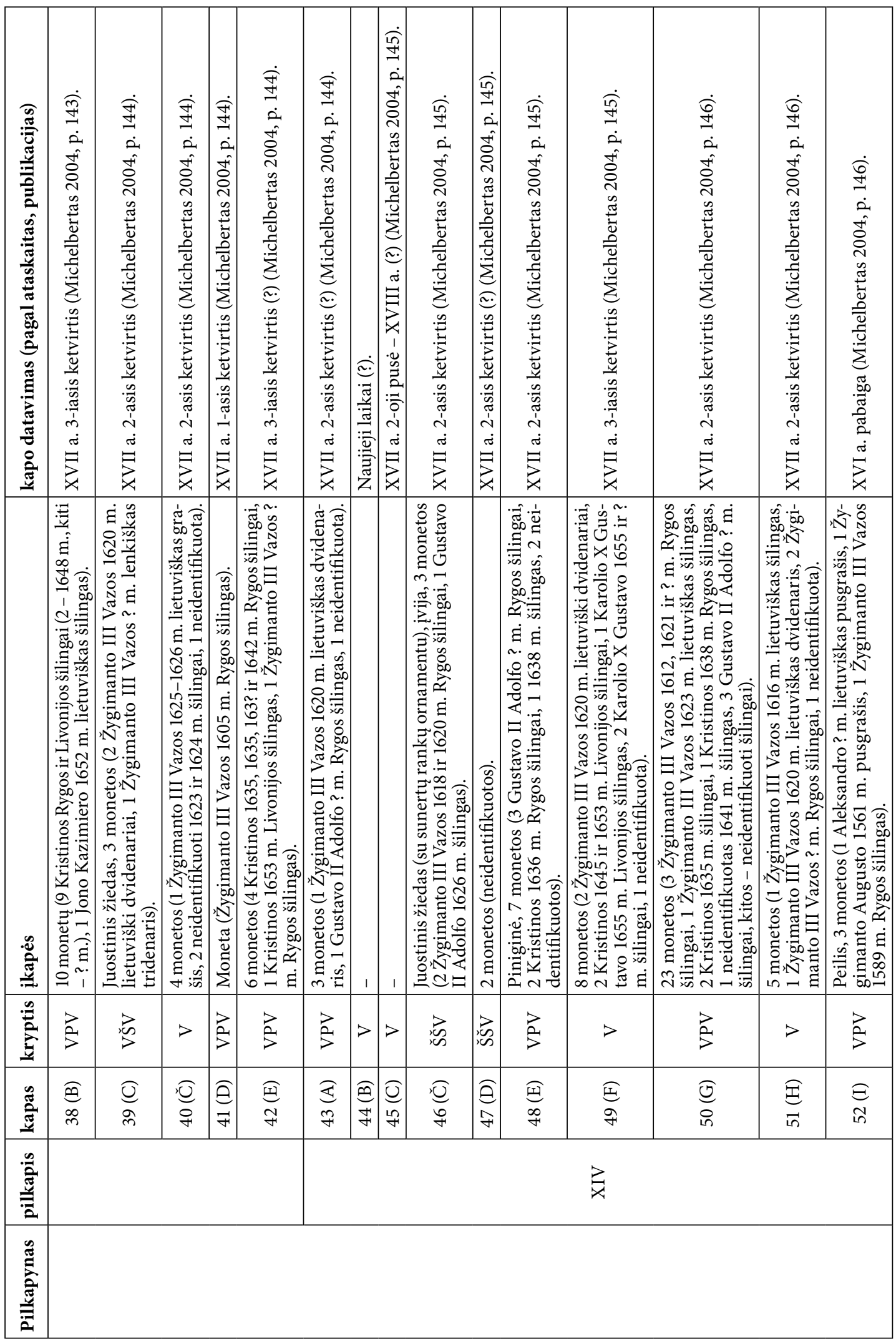


3

\begin{tabular}{|c|c|c|c|c|c|c|c|c|c|c|c|c|c|c|c|c|c|c|c|c|c|}
\hline 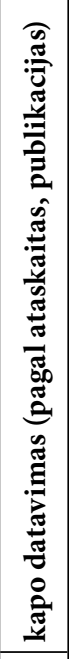 & 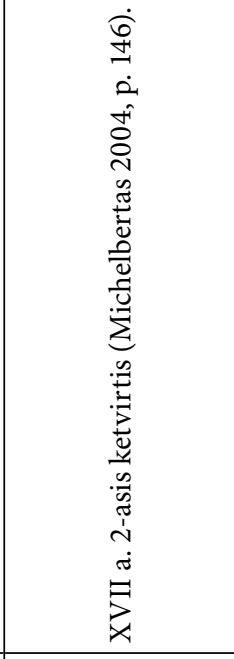 & 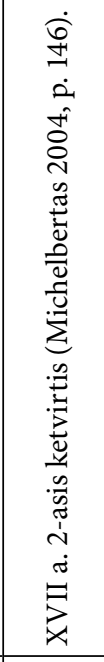 & 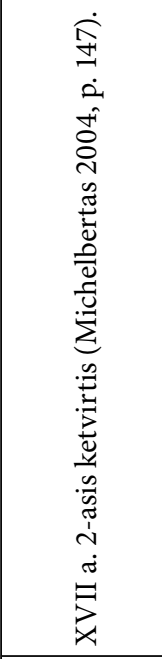 & 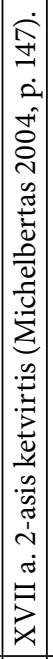 & 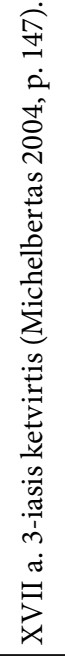 & 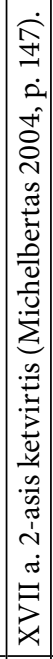 & 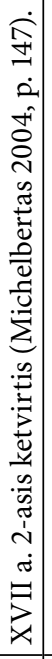 & 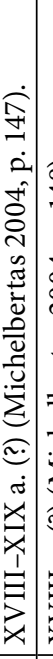 & 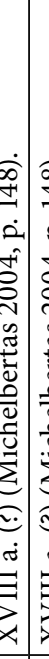 & 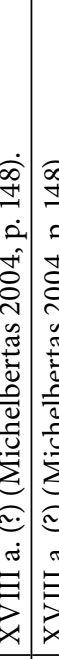 & 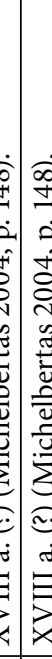 & 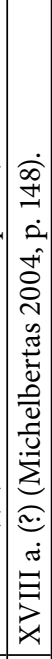 & 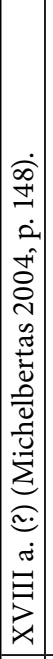 & 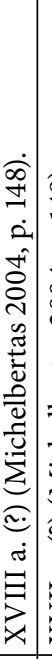 & 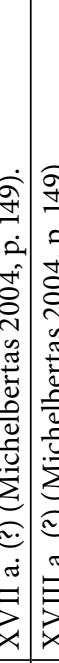 & 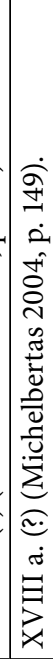 & 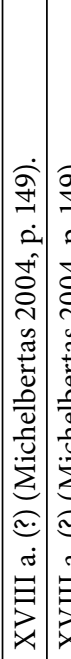 & 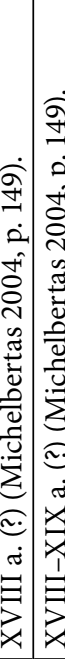 & 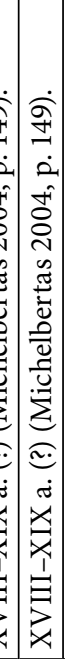 & 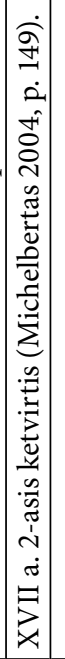 & 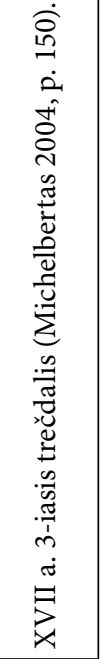 \\
\hline 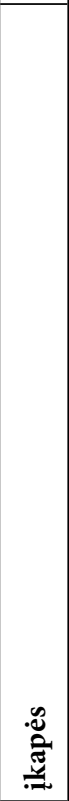 & 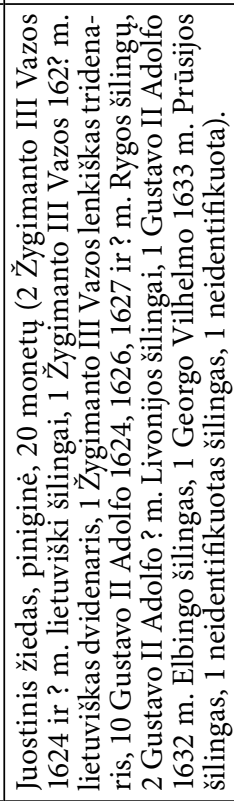 & 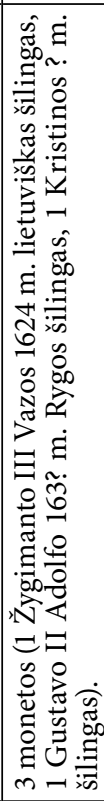 & 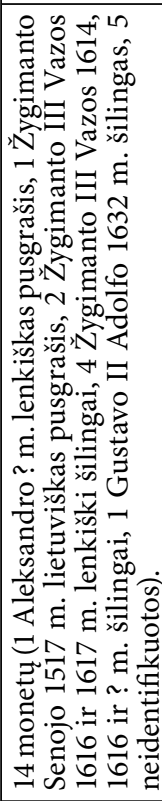 & 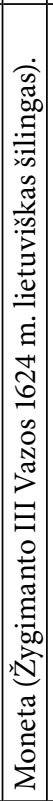 & 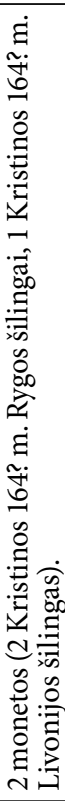 & 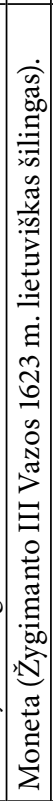 & 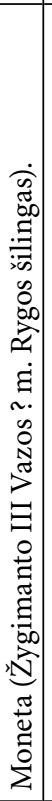 & 1 & & 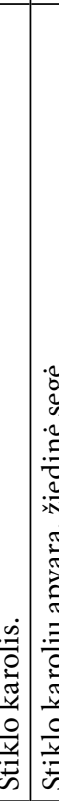 & 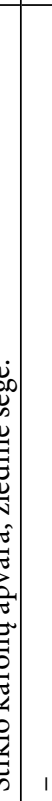 & & 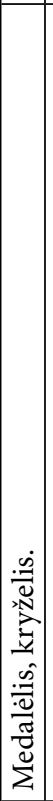 & & 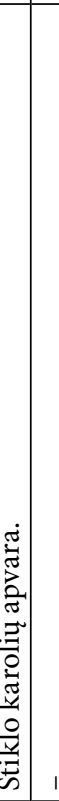 & 1 & 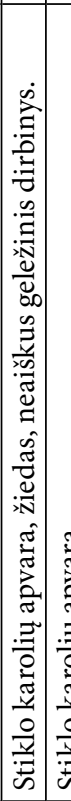 & 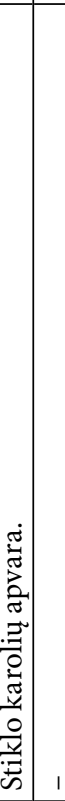 & \begin{tabular}{|l|l} 
& \\
& \\
\end{tabular} & 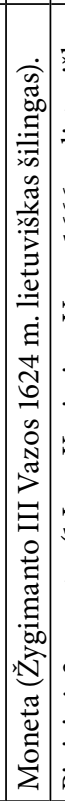 & 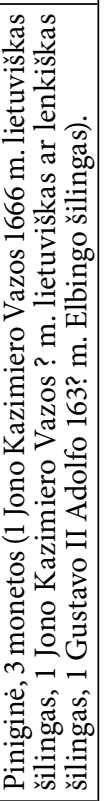 \\
\hline 竞 & in & $>$ & $>$ & $>$ & z & 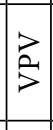 & 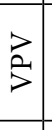 & $>2$ & $>1=$ & $>1>$ & $>>$ & 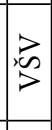 & in & $>$ & $>$ & 总 & $>$ & $\begin{array}{l}3 \\
5\end{array}$ & in & $>$ & 考 \\
\hline $\begin{array}{l}\mathscr{\Xi} \\
\text { : } \\
\text { ت्ञ }\end{array}$ & $\underset{n}{\infty}$ & $\underset{\text { in }}{\stackrel{4}{4}}$ & $\underset{i n}{\vec{\theta}}$ & 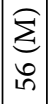 & $\begin{array}{l}\widehat{Z} \\
\text { in }\end{array}$ & $\begin{array}{c}0 \\
\infty \\
\infty \\
i n\end{array} \mid$ & $\begin{array}{l}\widehat{\Xi} \\
\text { à }\end{array}$ & $\begin{array}{l}\vec{\Xi} \\
8 \\
8\end{array}$ & $\frac{0}{\sigma}$ & 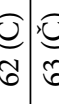 & $\widehat{b}$ & 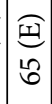 & $\mid \begin{array}{l}\text { 空 } \\
\stackrel{0}{0}\end{array}$ & & 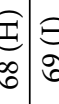 & $\begin{array}{l}E \\
\circ \\
R\end{array}$ & 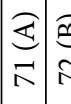 & 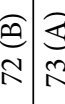 & 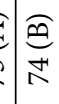 & 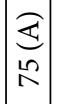 & 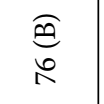 \\
\hline $\begin{array}{l}\frac{\infty}{\vec{z}} \\
\frac{\vec{z}}{\bar{z}}\end{array}$ & & & & & & & & & & $\vec{x}$ & & & & & & & $\stackrel{B}{\vec{\lambda}}$ & & $\underset{\rtimes}{\nexists ~}$ & & 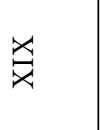 \\
\hline 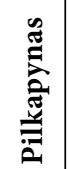 & & & & & & & & & & & & & & & & & & & & & \\
\hline
\end{tabular}




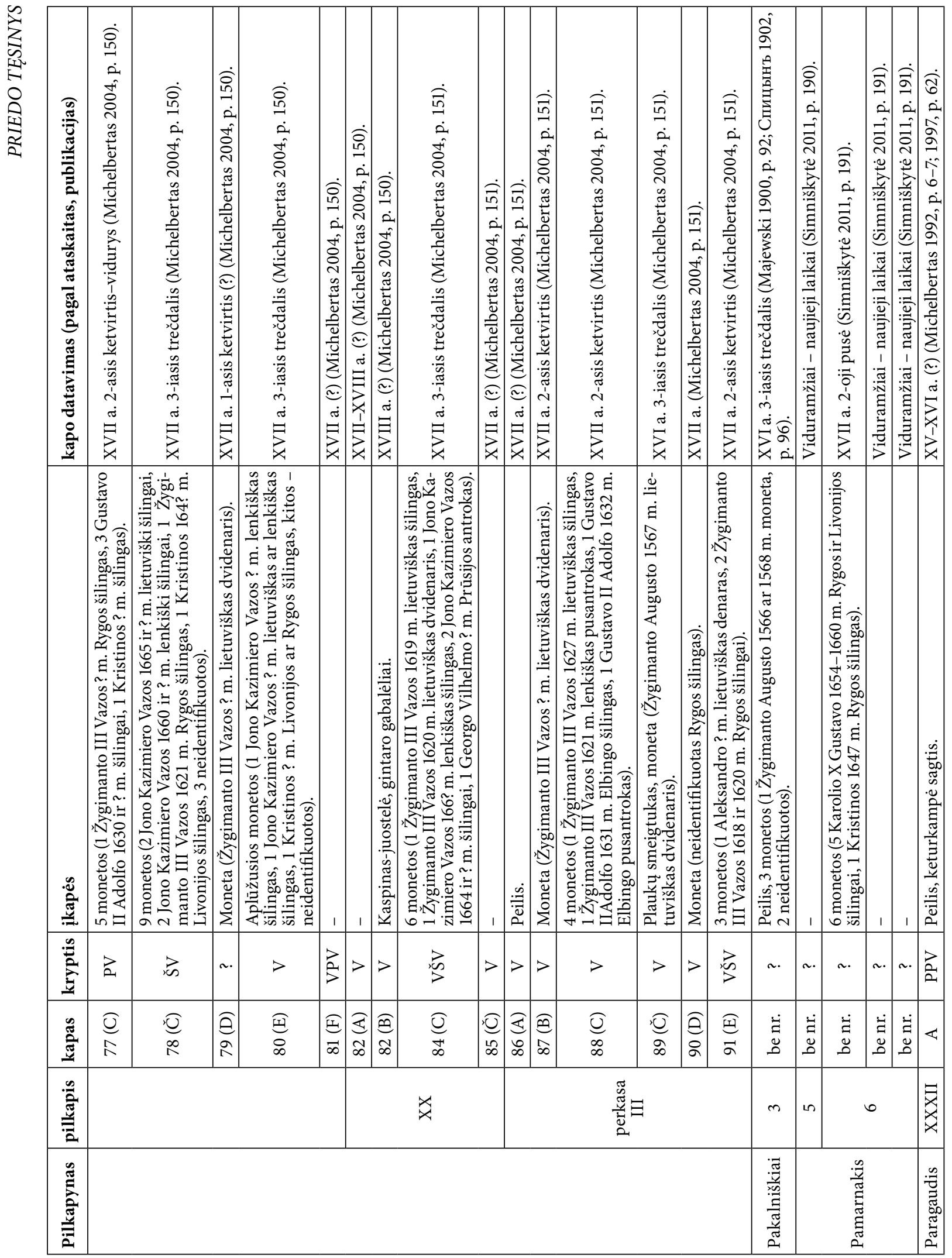


2
$\vdots$
5
0
0
$\frac{1}{2}$
$\frac{1}{2}$

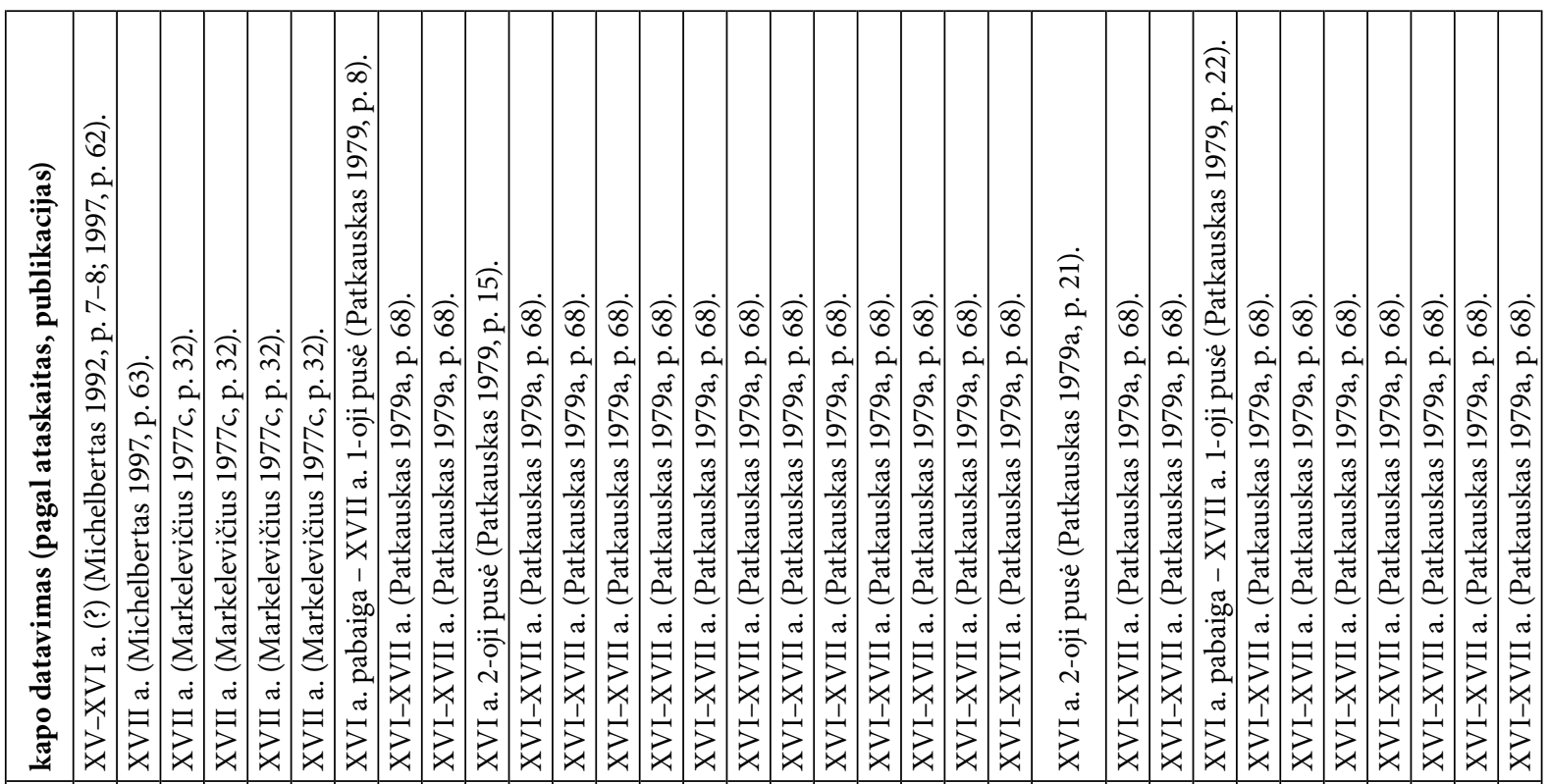

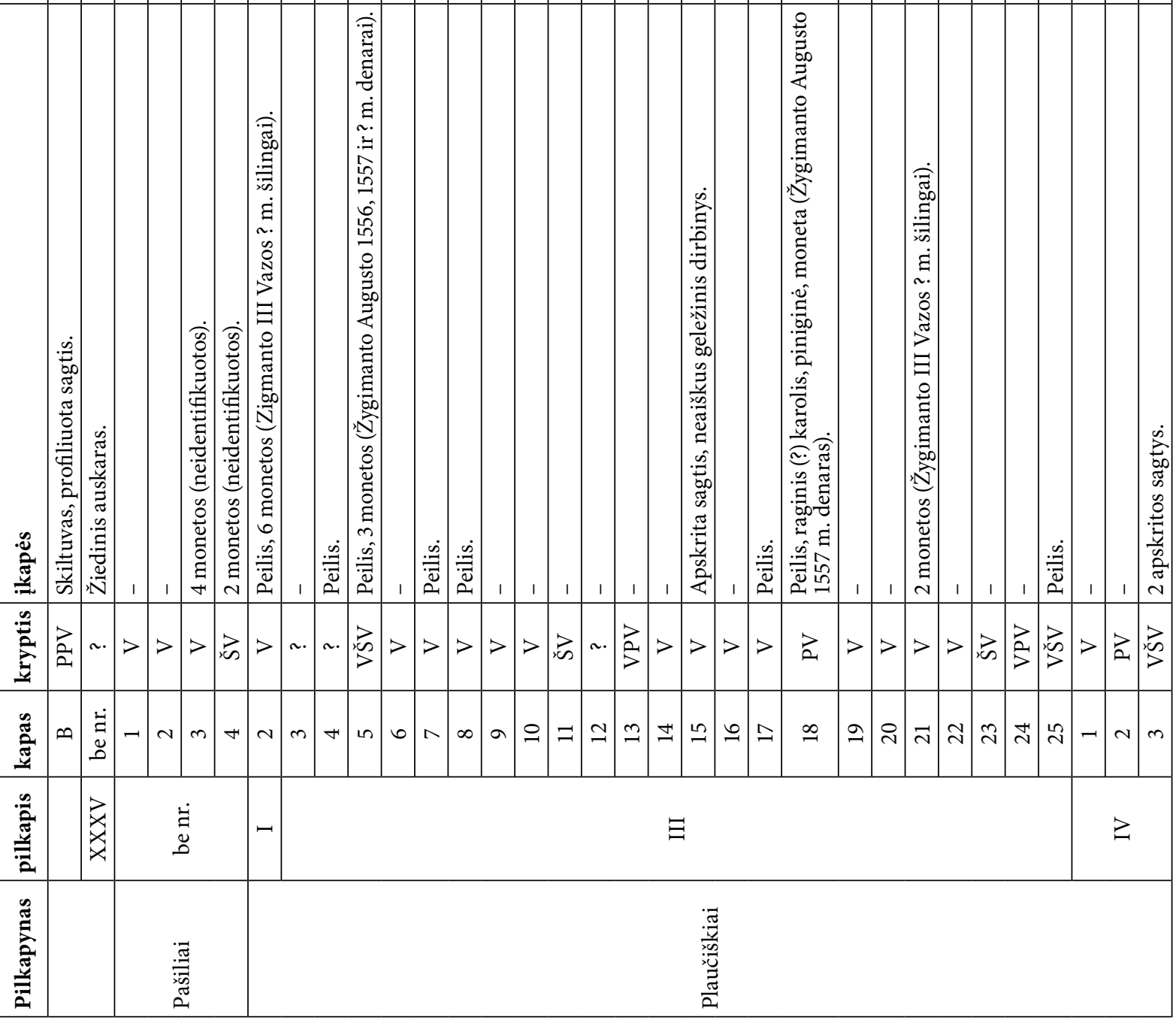




\begin{tabular}{|c|c|c|c|c|c|c|c|c|c|c|c|c|c|c|c|c|c|c|c|c|c|c|}
\hline 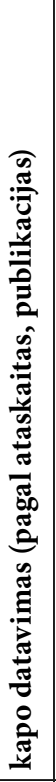 & 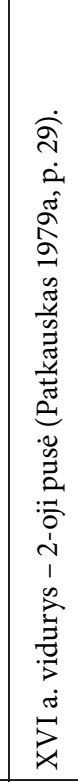 & 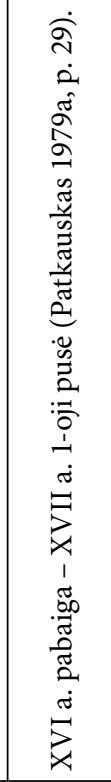 & 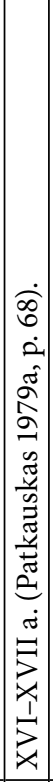 & 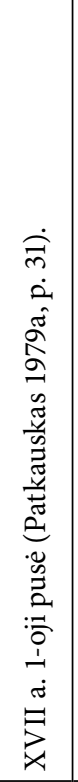 & 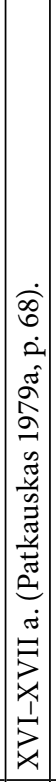 & 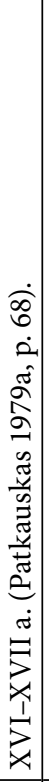 & 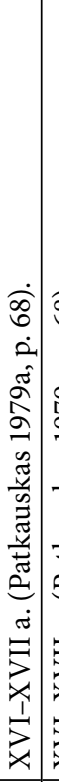 & 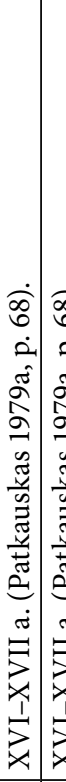 & 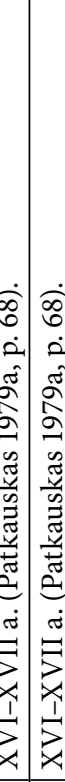 & 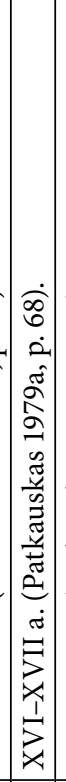 & 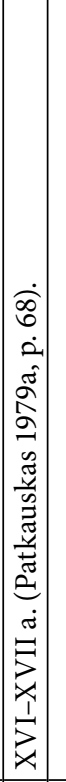 & 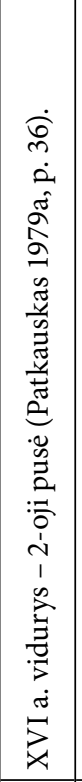 & 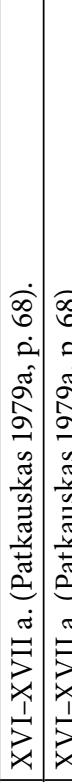 & 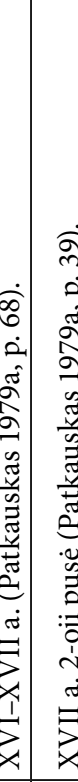 & 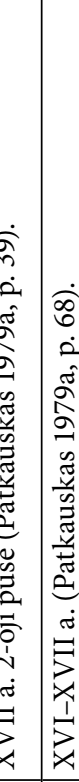 & 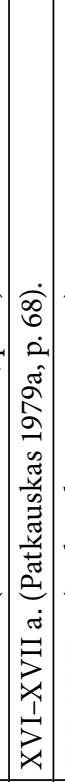 & 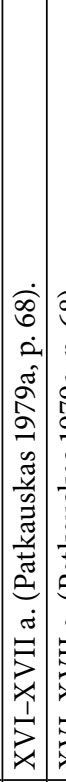 & 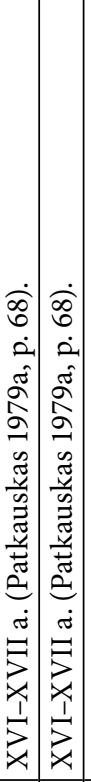 & 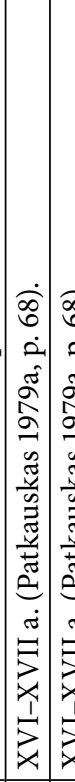 & 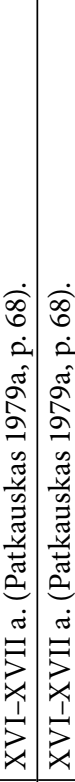 & 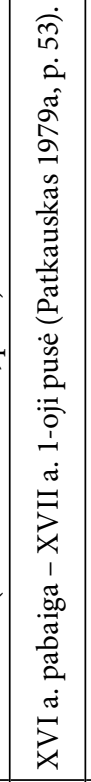 & 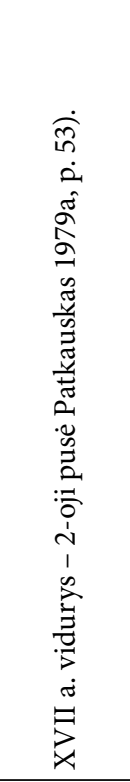 \\
\hline 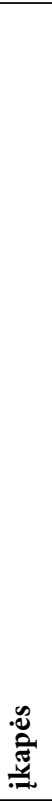 & 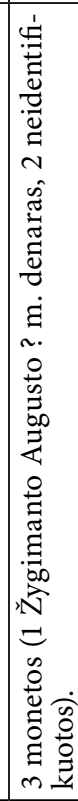 & 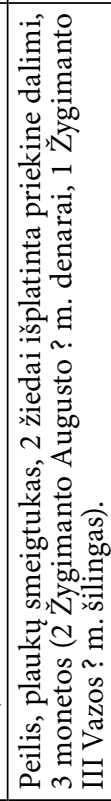 & 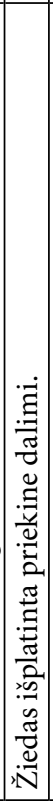 & 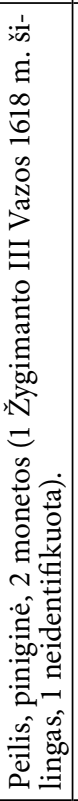 & 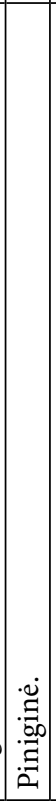 & 1 & 1 & 1 & 1 & 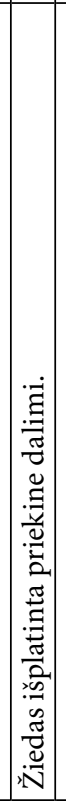 & & 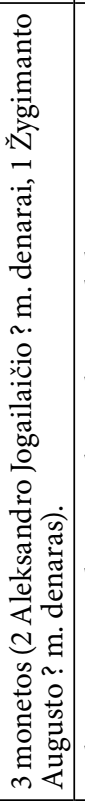 & 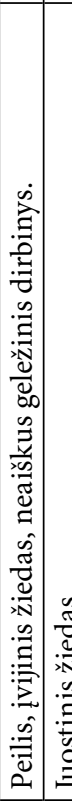 & 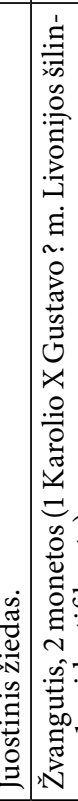 & 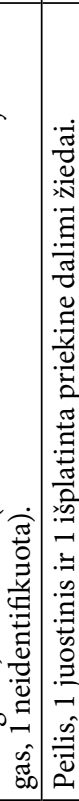 & . & 18 & 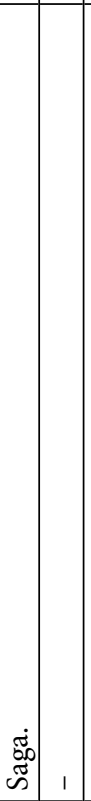 & & 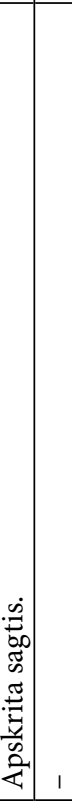 & 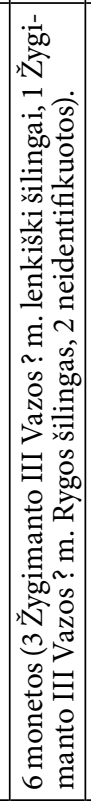 & 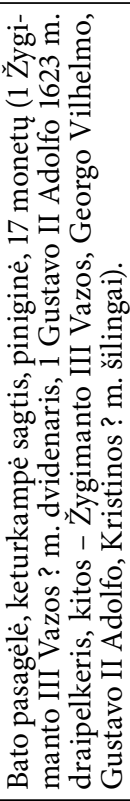 \\
\hline$\stackrel{0}{0}$ & $>$ & $>$ & 齐 & $>$ & $>$ & 变 & $>$ & $>1$ & co & $>$ & $>$ & $>$ & $\begin{array}{ll}\vec{a} \\
\overrightarrow{3}\end{array}$ & s & $\frac{5}{5}$ & $>$ & is & \begin{tabular}{l|l}
$\vec{a}$ \\
$\overrightarrow{1}$ \\
$>$
\end{tabular} & $>$ & $>\mid \begin{array}{l}\vec{a} \\
\vec{a}\end{array}$ & $\stackrel{2}{a}$ & $\stackrel{\vec{a}}{>}$ \\
\hline 营 & $r$ & in & 0 & $\wedge$ & $\infty$ & $a$ & 으 & $\Rightarrow=$ & $\approx=$ & $\Xi$ & 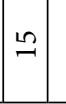 & 눙 & $\triangle \propto$ & $\infty$ & $\sim$ & + & $\Rightarrow$ & $\simeq \cong$ & $\exists L$ & $\sim \sim \sim$ & $m$ & $r$ \\
\hline 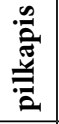 & & & & & & & & & & & & & & & $>$ & & & 5 & & & $\overrightarrow{5}$ & \\
\hline
\end{tabular}


永

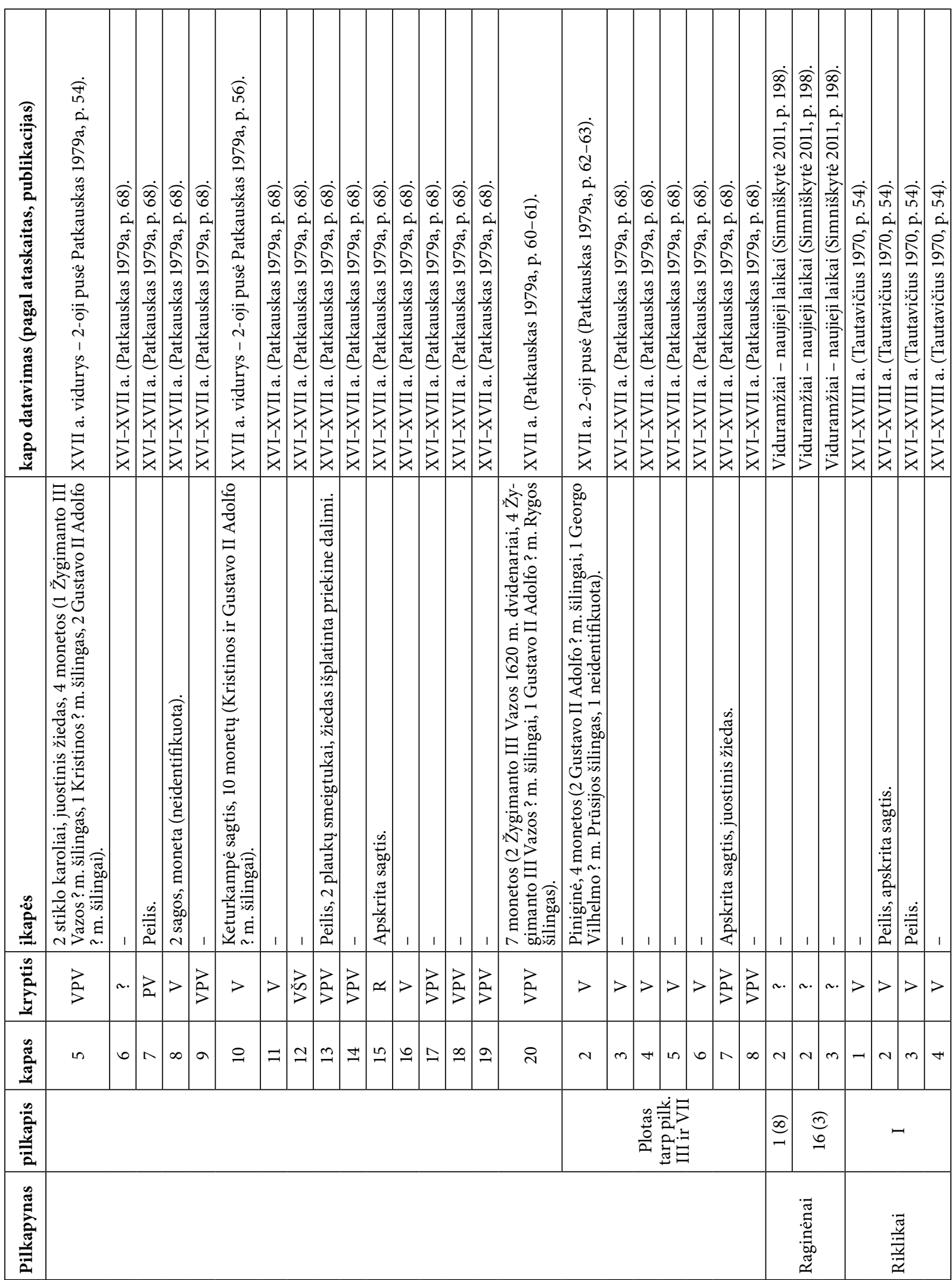




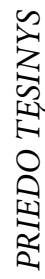

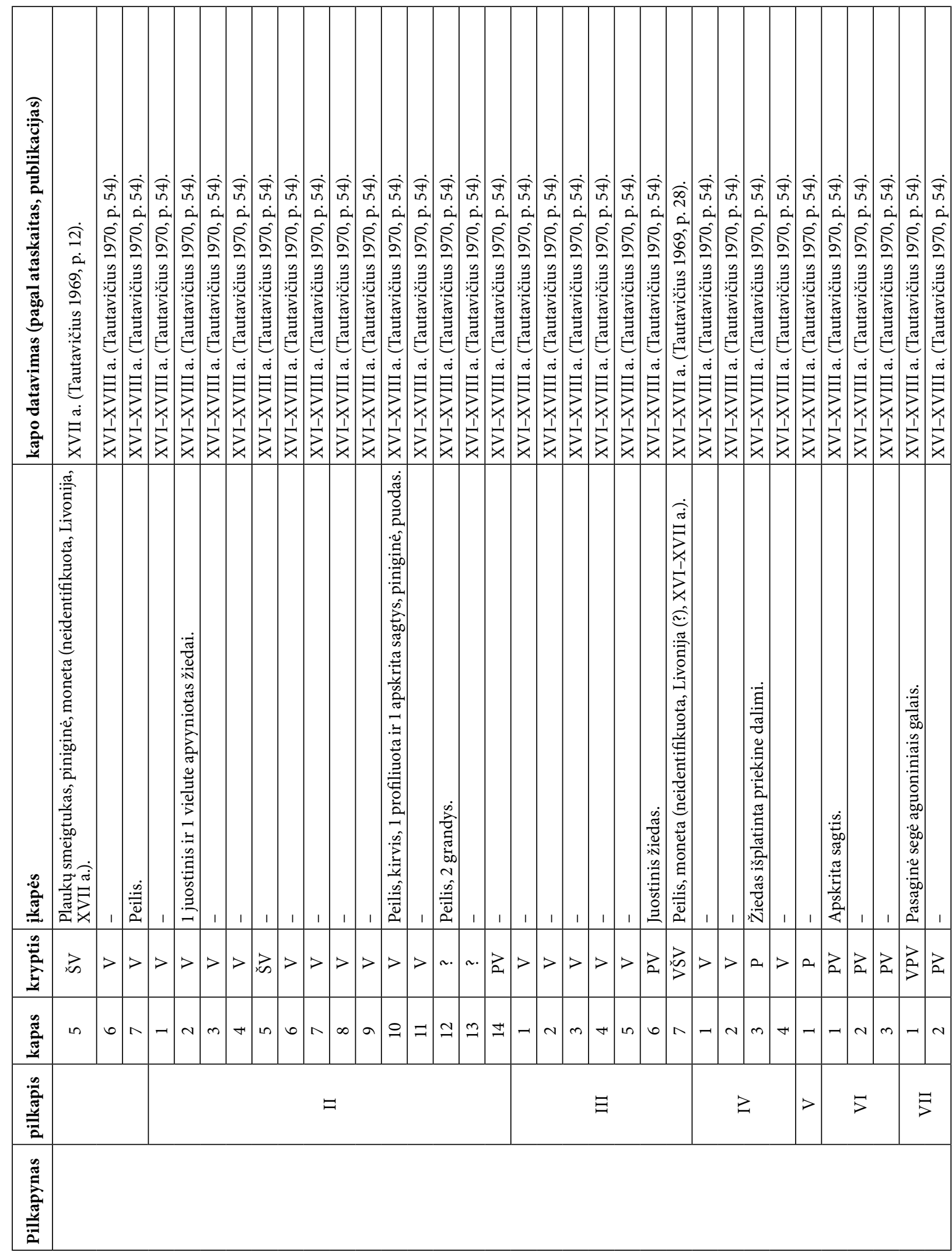


3
$\vdots$
0
0
0
$\frac{1}{2}$
$\frac{1}{2}$

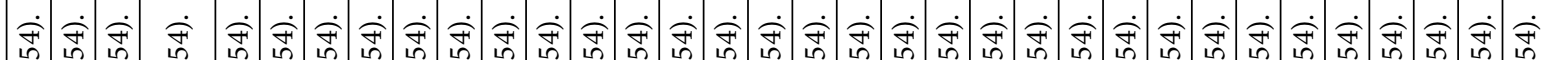

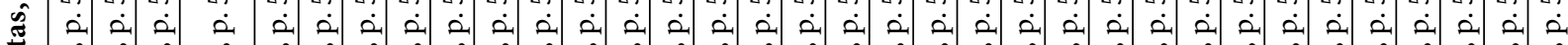

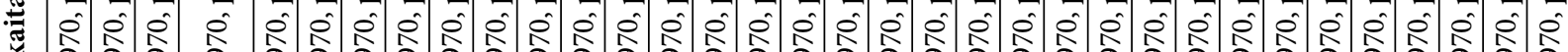

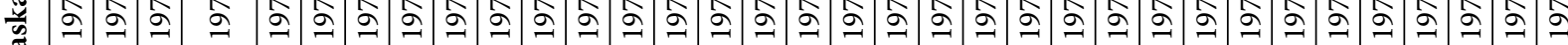
䒕

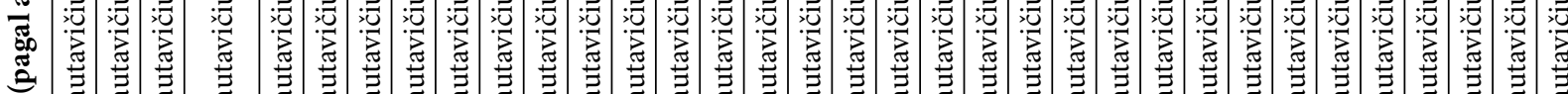
吾 .

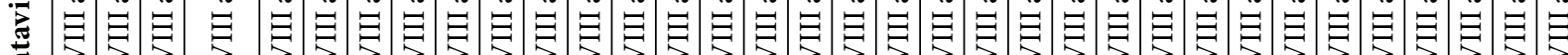

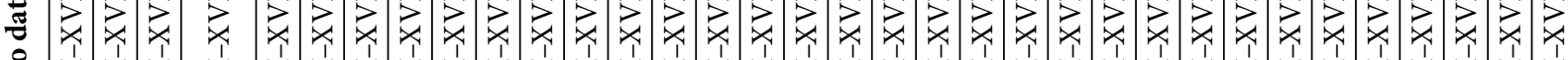

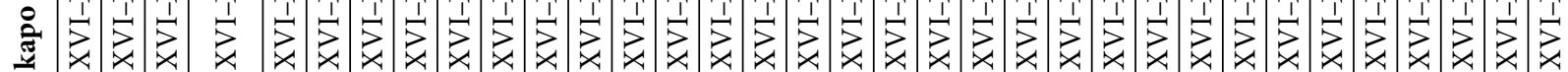

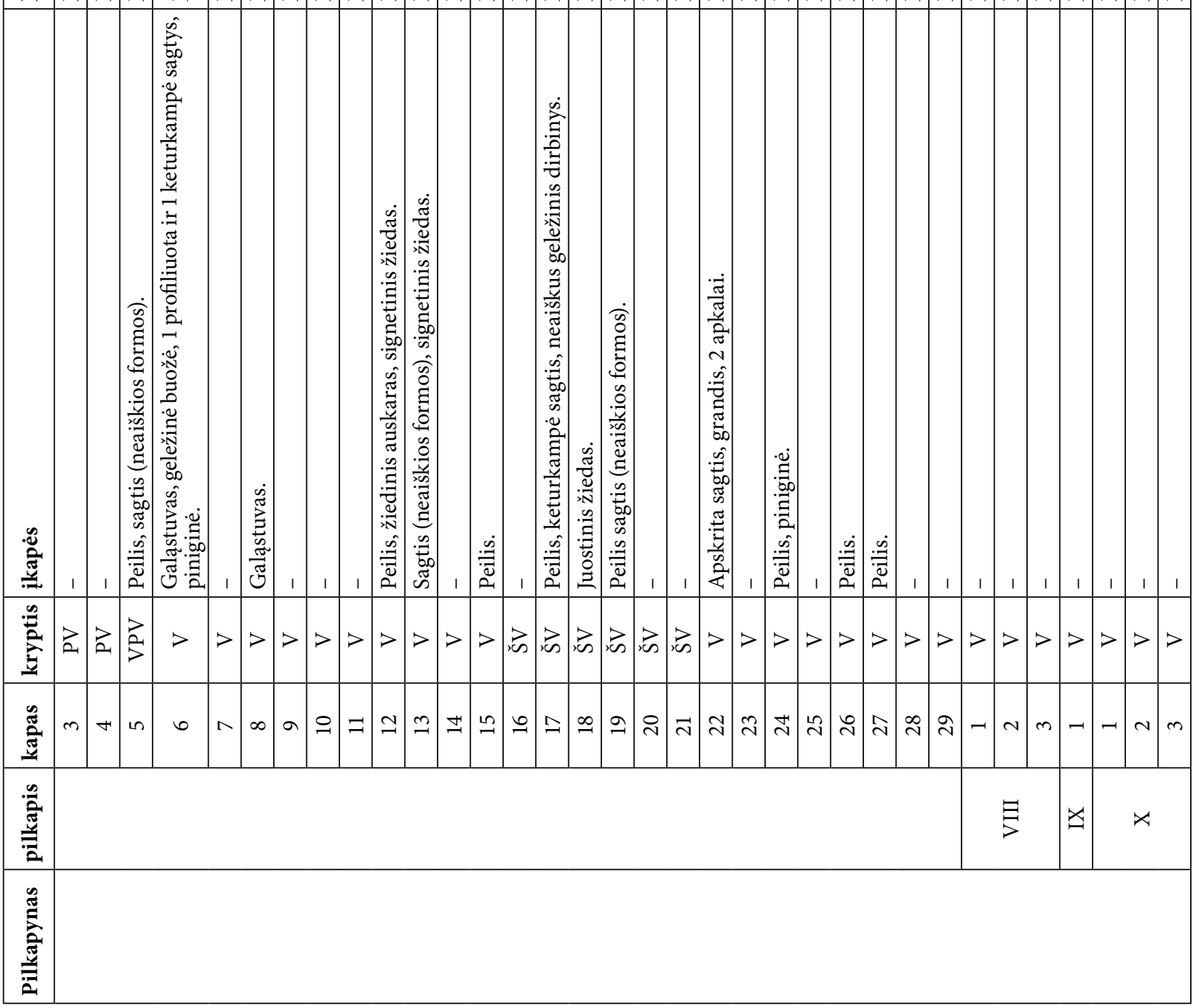


3

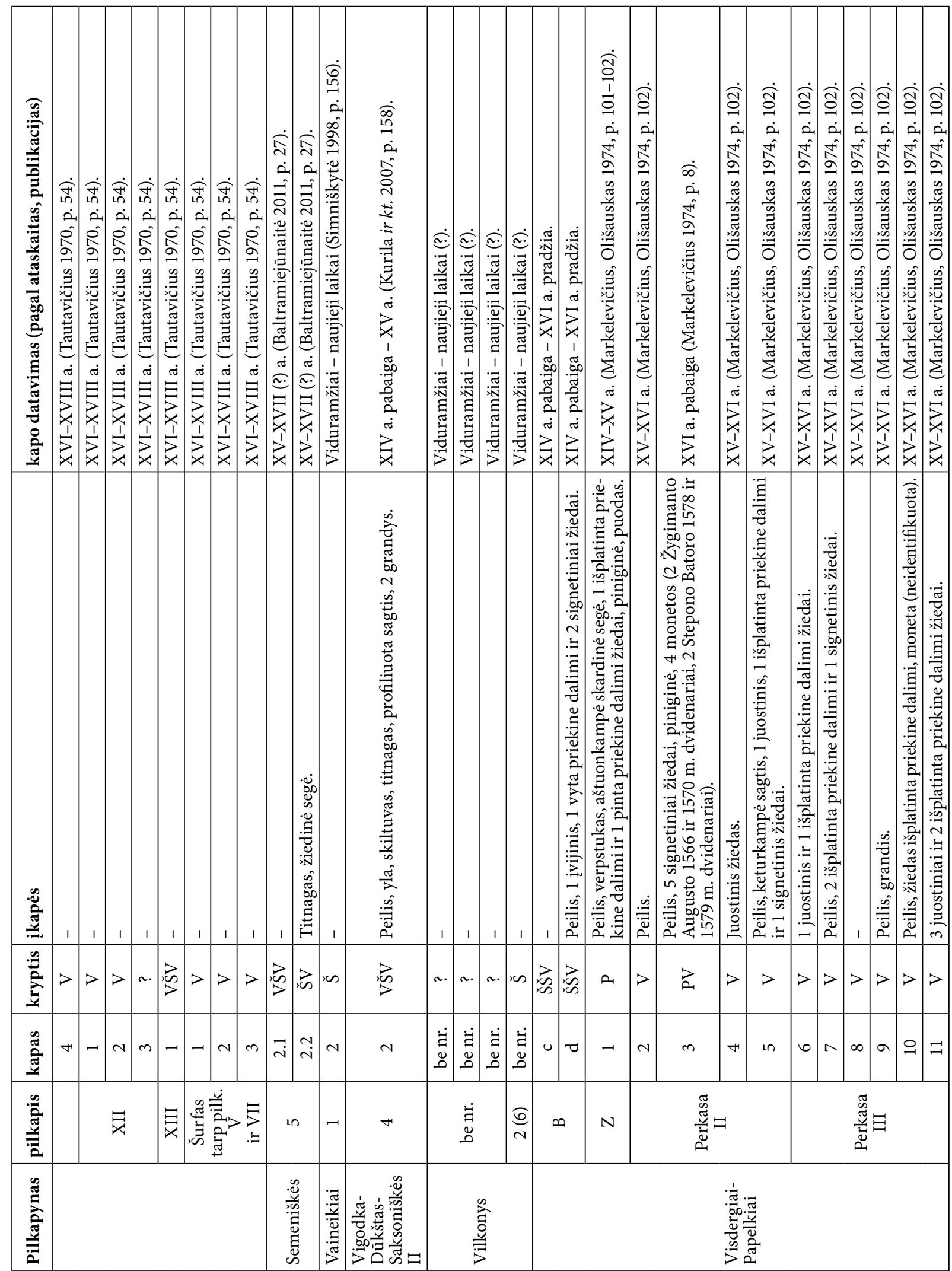




\section{ŠALTINIŲ IR LITERATŪROS SĄRAŠAS}

Artelius, T., 2013. Inventions of Memory and Meaning - Examples of Late Iron Age Reuse of Bronze Age Monuments in South-Western Sweden. In: Fontijn, D., Louwen, A.J., van der Vaart, S.A., Wentink, K., eds. Beyond Barrows: Current Research on the Structuration and Perception of the Prehistoric Landscape through Monuments. Leiden: Sidestone Press, 21-40.

Aspöck, E., 2009. The relativity of normality: An archaeological and anthropological study of deviant burials and different treatment at death (daktaro disertacija). University of Reading.

Balčiūnas, J., 1987. 1985 metu žvalgomosios archeologinès ekspedicijos Ignalinos rajone ataskaita. LIIR, F. 1, b. 2247.

Baltramiejūnaitè, D., 2011. Semeniškiu senovès gyvenvietés II ir jos aplinkos (u. k. 24574, Širvintu raj.) $2009 \mathrm{~m}$. archeologiniu tyrinejimu ataskaita. LIIR, F. 1, neinventorinta.

Baltramiejūnas, A., 1934. Gilbonių Kapmilžiai. Panevėžio balsas, rugpjūčio mèn. 12 d., 3.

Banytè-Rowell, R., Kurila, L., Simniškytè-Strimaitienè, A., 2016. Wartość naukowa „Inwentarza archeologicznego gubernji kowieńskiej” Michała Brensztejna. In: Bitner-Wróblewska, A., Banytė-Rowell, R., red. Inwentarz archeologiczny guberni kowieńskiej Michała Eustachego Brensztejna (=Aestorum Hereditas, III), 2. Warszawa: Państwowe Muzeum Archeologiczne, 174-295.

Baronas, D., Černius, R., Jovaiša, L., Paknys, M., Raila, E., Streikus, A., Subačius, P., 2006. Ališauskas, V., sud. Krikščionybès Lietuvoje istorija. Vilnius: Aidai.

Baronas, D., Rowell, S.C., 2015. The Conversion of Lithuania: From Pagan Barbarians to Late Medieval Christians. Vilnius: The Institute of Lithuanian Literature and Folklore.

Basanavičius, J., 1936. D-ro Jono Basanavičiaus autobiografija. Vilnius: Lietuvių mokslo draugijos leidinys.
Beresnevičius, G., 1990. Dausos. Pomirtinio gyvenimo samprata senojoje lietuviu pasauležiūroje. Vilnius: Gimtinè, Taura.

Błaszczyk, G., 1993. Diecezja żmudzka od XV wieku do początku XVII wieku. Ustrój (=Seria Historia, 180). Uniwersytet im. Adama Mickiewicza w Poznaniu.

Bumblauskas, M., 2015. Pagonybės anklavų klausimas Žemaitijos konversijoje (XVI a.). Sovijus. Tarpdalykiniai kultūros tyrimai, 3 (1), 10-20.

Butėnas, E., 1998. Maisiejūnų pilkapyno tyrinèjimai. $L A, 15,163-184$.

Butėnienè, E., 1971. Maisiejūnu pilkapyno, Kruonio apyl., Kaišiadoriu raj. kasinèjimu $1971 \mathrm{~m}$. liepos mèn. 7 d. - rugpiūčio 3 d. dienoraštis. LIIR, F. 1, b. 405.

Butènienè-Gintautaitè, E., 1961. Pažalvaičiu km., „Nemuno“ kolūkio Piniavos apyl., Panevėžio raj. senkapio 1961 m. tyrinejjimo dienoraštis. LIIR, F. 1, b. 158 .

Butrymówna, M., 1902. Kurhany w Niewieżnikach w pow. Poniewieskim. Światowit, IV, 148.

Cholodinska, A., 1978. Kivylių (Akmenès raj.) senkapis. AETL 1974 ir 1975 metais, 144-148.

Codex, 1984. Jatulis, P., col. Codex Mednicensis seu Samogitiae diocesis, I. 1416. II. 13 - 1609. IV. 2. Roma: Academia Lituana catholica scientiarum.

Codex, 1989. Jatulis, P., col. Codex Mednicensis seu Samogitiae diocesis, II. 1609. VI. 26 - 1926. V. 13. Roma: Academia Lituana catholica scientiarum.

Crewe, V.A., 2010. Barrows and Buildings, Ditches and Dwellings: The Appropriation of Prehistoric Monuments in Early to Middle Anglo-Saxon Settlements (daktaro disertacija), 1. University of Sheffield.

Curta, F., 2016. Burials in Prehistoric Mounds: Reconnecting with the Past in Early Medieval Greece. Revue des Études Byzantines, 74, 269-285.

Dowgird, T., 1888. Pamiątki z czasów przedhistorycznych na Żmujdzi. Mełżyn-Kapas w fol. Wizdergi. Opis robót dokonanych na tem cmentarzysku w roku 1884 i 1885. Pamiętnik Fizyjograficzny, VIII (IV. Antropologija), 3-17. 
Effros, B., 1997. De partibus Saxoniae and the Regulation of Mortuary Custom: A Carolingian Campaign of Christianization or the Suppression of Saxon Identity? Revue belge de Philologie et d'Histoire, 75 (2), 267-286.

Fahlander, F., 2016. The Materiality of the Ancient Dead: Post-burial Practices and Ontologies of Death in Southern Sweden AD 800-1200. Current Swedish Archaeology, 24, 137-162.

Gardeła, L., Kajkowski, K., 2013. Vampires, criminals or slaves? Reinterpreting, deviant burials in early medieval Poland. WA, 45 (5), 780-796.

Girininkas, A., 1976. 1976 m. žvalgomieji kasinejjimai Druskiu pilkapiuose, Kupiškio raj. LIIR, F. 1, b. 503 .

Halsall, G., 2010. Cemeteries and Society in Merovingian Gaul. Selected Studies in History and Archaeology, 1992-2009 (=Brill's Series on the Early Middle Ages, 18). Leiden, Boston: Brill.

Hejhal, P., Lutovský, M., 2012. In agris sive in silvis... Secondary medieval burials in ancient barrows in Bohemia. In: Salamon, M., Wołoszyn, M., Musin, A., Špehar, P., Hardt, M., Kruk, M.P., SulikowskaGąska, A., eds. Rome, Constantinople and NewlyConverted Europe. Archaeological and Historical Evidence, I. Kraków: Poligrafia Inspektoratu Towarzystwa Salezjańskiego, 517-524.

Holtorf, C.J., 1998. The Life-Histories of Megaliths in Mecklenburg-Vorpommern (Germany). WA, 30 (1), 23-38.

Hutton, R., 2011. Romano-British Reuse of Prehistoric Ritual Sites. Britannia, 42, 1-22.

Jovaiša, L., par., 1998. Žemaičiu vyskupijos vizitacija (1579) (=Fontes ecclesiastici historice Lithuanioe, I). Vilnius: Aidai.

Jučas, M., 2007. Lietuvos parapijos XV-XVIII a. Vilnius: Aidai.

Kazakevičius, V., 2000a. Sèlių kapai Miškinių pilkapyje. $L A, 20,115-139$.

Kazakevičius, V., 2000b. Visètiškių pilkapynas. LA, 20, 21-99.
Kaznakov, V., 2013. Treatment of the "special“ dead in the Early Middle Ages: Anglo-Saxon and Slavic Perspectives (daktaro disertacija). University of Glasgow.

Kultūros, 2019. Kultūuros vertybiu registras. Prieiga per: https://kvr.kpd.lt/\#/static-heritage-search [Žiūrèta $2019 \mathrm{~m}$. vasario 8 d.].

Kurila, L., 2003. Rytų Lietuvos pilkapių kultūros nykimo klausimu. Lietuvos aukštujų mokyklų mokslo darbai: Istorija, LVIII, 25-38.

Kurila, L., 2015. Žmonių kaulų iš Rytų Lietuvos pilkapių AMS ${ }^{14} \mathrm{C}$ datavimas: rezultatai, perspektyvos. $L A, 41,45-80$.

Kurila, L., 2016. East Lithuanian Barrows - Burial in the Cradle of Lithuanian Tribes. In: Zabiela, G., Baubonis, Z., Marcinkevičiūte, E., eds. A Hundred Years of Archaeological Discoveries in Lithuania. Vilnius: Society of the Lithuanian Archaeology, 192-207.

Kurila, L., Baubonis, Z., Kliaugaitė, V., 2007. Vigodkos (Dūkšto, Saksoniškių) II pilkapynas. $L A, 32$, 145-170.

Lietuvos, 1977. Lietuvos TSR archeologijos atlasas, III. I-XIII a. pilkapynai ir senkapiai. Vilnius: Mokslas.

Lukšaitè, I., 1999. Reformacija Lietuvos Didžiojoje Kunigaikštystejje ir Mažojoje Lietuvoje. XVI a. trečias dešimtmetis - XVII a. pirmas dešimtmetis. Vilnius: Baltos lankos.

Majewski, E., 1900. Kurhany na Pakalniszkach w pow. Poniewieskim (Tumulis à Pakalniszki) zbadane przez Maryę Butrymównę. Światowit, II, 92-103.

Markelevičius, J., 1974. Papelkiu - Visdergiu pilkapio ir senkapio (Šiauliu raj.) tyrinejjimy ataskaita (1973 m. liepos mèn. 5 - 15 d.d.). LIIR, F. 1, b. 383.

Markelevičius, J., 1977a. Kelmes rajono archeologijos paminklǔ žvalgymo ir žvalgomujų archeologiniu tyrinèjimu ataskaita (1974 m. rugpiūčio 1-31 d. d.). LIIR, F. 1, b. 470.

Markelevičius, J., 1977b. Muoriškiu pilkapių (Biržu raj., Nemunèlio Radviliškio apyl.) archeologiniu. 
tyrimu ataskaita (1974 m. birželio 17 d.-liepos 5 d., 1975 m. birželio 2-22 d.d.). LIIR, F. 1, b. 464.

Markelevičius, J., 1977c. Žvalgomujų archeologiniu tyrinejimu Panevėžio rajone ataskaita (1975 m. balandžio mèn.). LIIR, F. 1, b. 460.

Markelevičius, J., Morauskienė, E., 1977. Muoriškių (Biržų raj.) pilkapių tyrinėjimai 1974 ir 1975 metais. ATL 1974 ir 1975 metais, 87-93.

Markelevičius, J., Olišauskas, R., 1974. Papelkių-Vizdergių (Šiaulių raj.) pilkapio ir senkapio tyrinejjimai 1973 m. AETL 1972 ir 1973 metais, 101-102.

Meurkens, L., 2010. The late medieval/ Early Modern reuse of prehistoric barrows as execution sites in the southern part of the Netherlands. Journal of Archaeology in the Low Countries, 2 (2), 5-29.

Michelbertas, M., 1970a. Ataskaita už 1969 m. liepos 4 - rugpiūčio 5 d. tyrinèjimus Kybartiškès pilkapyne, Šiauliu raj. LIIR, F. 1, b. 300.

Michelbertas, M., 1970b. Ataskaita už $1970 \mathrm{~m}$. liepos 24-28d. archeologinius tyrinejimus Berklainiu pilkapyje, Pasvalio raj. LIIR, F. 1, b. 308.

Michelbertas, M., 1992. Ataskaita už 1991 m. archeologinius tyrinèjimus Paragaudžio pilkapyne (Šilales raj.). LIIR, F. 1, b. 1820.

Michelbertas, M., 1997. Paragaudžio pilkapynas. Vilniaus universitetas.

Michelbertas, M., 2004. Pajuosčio pilkapynas. Vilniaus universitetas.

Michelbertas, M., 2006. Akmeniu ir Perkūniškès pilkapiai. Vilniaus universitetas.

Michelbertas, M., 2011. Paalksniu archeologijos paminklai. Vilniaus universitetas.

Michelbertas, M., 2016. Samogitian and North Lithuanian Barrows. In: Zabiela, G., Baubonis, Z., Marcinkevičiūtè, E., eds. A Hundred Years of Archaeological Discoveries in Lithuania. Vilnius: Society of the Lithuanian Archaeology, 286-301.

Milella, M., Mariotti, V., Belcastro, M.G., Knüsel, Ch.J., 2015. Patterns of Irregular Burials in Western Europe $\left(1^{\text {st }}-5^{\text {th }}\right.$ Century A.D.). PLoS One,
10 (6). Prieiga per: https://www.ncbi.nlm.nih.gov/ pubmed/26115408 [Žiūrèta $2019 \mathrm{~m}$. sausio 24 d.].

Monumenta, 1863. Pertz, G.H., ed., Monumenta Germaniae Historica inde ab anno Christi quingentesimo usque ad annum millesimum et quingentesimum. Legum, III. Hannoverae: Impensis Bibliopolii Aulici Hahniani.

Muižnieks, V., 2015. Bēru tradīcijas Latvijā pēc arheologiski pètīto 14.-18. gadsimta apbedī̌̌anas vietu materiāla (=Latvijas Nacionālā vēstures muzeja raksti, 21). Rīga: Latvijas Nacionālais vēstures muzejs.

Murphy, E.M., ed., 2008. Deviant Burial in the Archaeological Record. Oxford: Oxbow Books.

Niesiecki, K., 1839. Herbarz Polski Kaspra Niesieckiego S. J. powiększony dodatkami z poźniejszych autorów, rękopismów, dowodów urzędowych i wydany przez Jana Nep. Bobrowicza, II. Lipsk: Nakładem i drukiem Breitkopfa i Hærtela.

Ochmański, J., 1972. Biskupstwo Wileńskie w średniowieczu: Ustrój i uposażenie(=Seria Historia, 55). Uniwersytet im. Adama Mickiewicza w Poznaniu.

Ostašenkovienè, V., 2015. Fr Juozapas Žiogas: Archaeologist and Priest. Archaeologia Baltica, 2122, 121-133.

Patkauskas, S., 1979a. Plaučiškių /Pakruojo raj./ pilkapyno tyrimai 1978 metais. Ataskaita, I. LIIR, F. 1, b. 667.

Patkauskas, S., 1979b. Plaučiškių /Pakruojo raj./ pilkapyno 1978 metu tyrimai. Ataskaita, II. LIIR, F. 1, b. 667a.

Pedersen, A. 2006. Ancient mounds for new graves: An aspect of Viking Age burial customs in southern Scandinavia. In: Andren, A., Jennbert, K., Raudvere, C., eds. Old Norse religion in long-term perspectives: Origins, changes, and interactions. An international conference in Lund, Sweden, June 3-7, 2004. Lund: Nordic Academic Press, 346-353.

Petrauskas, G., 2017. Laidosena viduramžiu Lietuvoje: mirusiuju deginimo paprotys (daktaro disertacija). Vilniaus universitetas. 
Petrulis, D., 2018. Lakštingalų kapinynas. ATL 2017 metais, 161-166.

Proligis, 2019. GIS duomenu bazè PROLIGIS. Prieiga per: http://www.archaeolandscape.if.vu.lt/node/2 [Žiūrèta 2019 m. vasario 8 d.].

Radiņš, A., 1999. 10.-13. gadsimta senkapi latgaḷu apdzīvotajā teritorijā un Austrumlatvijas etniskās, sociālās un politiskās vēstures jautājumi (=Latvijas Vēstures muzeja raksti, 5). Rīga: N.I.M.S.

Reynolds, A., 2009. Anglo-Saxon Deviant Burial Customs. Oxford University Press.

Roymans, N., 1995. The cultural biography of urnfields and the long-term history of a mythical landscape. Archaeological Dialogues, 1, 2-38.

Semėnas, V., 1995. Kretuonu 1-os pilkapiu grupès (Švenčioniu raj.) tyrinejimu 1994 metais ataskaita. LIIR, F. 1, b. 2266.

Semple, S., 1998. A fear of the past: the place of the prehistoric burial mound in the ideology of middle and later Anglo-Saxon England. WA, 109-26.

Semple, S., Williams, H., 2015. Landmarks of the Dead: Exploring Anglo-Saxon Mortuary Geographies. In: Hyer, M.C., Owen-Crooker, G.R., eds. The Material Culture of the Built Environment in the Anglo-Saxon World (=The Material Culture of Daily Living in the Anglo-Saxon World, II). Liverpool University Press, 137-161.

Simniškytè, A., 1998. Vaineikių pilkapyno tyrinèjimai 1997 metais. ATL 1996 ir 1997 metais, 155-156.

Simniškytè, A., 2011. Ivano Abramovo archeologiniai kasinejimai Lietuvoje. In: Luchtanas, A., Tamulynas, L., sud. Lietuvos archeologijos šaltiniai Sankt Peterburge. Vilniaus universitetas, 183-285.

Simniškytè, A., 2013. Geležies amžius Sèloje. Vilnius: Diemedžio leidykla.

Simniškytè, A., 2018. Atypical burial rites or destruction of archaeological source? On the results of rescue excavations at Jakšiškis Barrow Cemetery (East Lithuania). Raport, 13, 137-153.

Steponaitis, V., 2006. Paduobès (Šaltaliūnès) III grupès pilkapynas. ATL 2004 metais, 87-91.
Svetikas, E., 2003. Alytaus kapinynas: Christianizacijos šaltiniai. Vilnius: Diemedis.

Svetikas, E., 2009. Lietuvos didžiosios kunigaikštystes christianizacija XIV a. pab. - XV a. Archeologiniai radiniai su krikščioniškais simboliais, I. Vilnius: Diemedis.

Šnore, E., 1993. Agrā dzelzs laikmeta uzkalniņi Latvijas austrumu daḷā. Rīga: Zinātne.

Tautavičius, A., 1951. Kurganai. Trakų r., Jagèliškių apyl., kolūkis „Už Tèvynę“. LIIR, F. 1, b. 15.

Tautavičius, A., 1952. 1951-1952 m. pilkapiu tyrinejimai Šalčininkų raj. LIIR, F. 1, b. 18.

Tautavičius, A., 1968. $1968 \mathrm{~m}$. žvalgomosios archeologines ekspedicijos ataskaita. LIIR, F. 1, b. 258.

Tautavičius, A., 1969. Riklikų, Anykščiu raj. pilkapiu 1969 m. tyrinèjimy ataskaita ir radiniu sąrašas. LIIR, F. 1, b. 257.

Tautavičius, A., 1970. Riklikų pilkapių kasinèjimai 1969 metais. AETL 1968 ir 1969 metais, 53-60.

Tautavičius, A., Urbanavičius, V., 1978. 1977 ir $1978 \mathrm{~m}$. žvalgomosios archeologinès ekspedicijos ataskaita (Anykščiu, Ukmergès ir Zarasu rajonai). LIIR, F. 1, b. 654 .

Tebelškis, P., 2000. Druskių senkapio tyrinèjimai 1998 m. ATL 1998 ir 1999 metais, 330-332.

Vaitkevičius, V., 2014. Etnogeografijos keliu, dar kartą atrasti Žemę. Liaudies kultūra, 2, 46-59.

Vaivada, V., 2004. Katalikų bažnyčia ir Reformacija Žemaitijoje XVI a.: esminiai raidos bruožai. Klaipèdos universitetas.

Van Beek, R., De Mulder, G., 2014. Circles, Cycles and Ancestral Connotations. The Long-term History and Perception of Late Prehistoric Barrows and Urnfields in Flanders (Belgium). Proceedings of the Prehistoric Society, 80, 299-326.

Van de Noort, R., 1993. The context of Early Medieval barrows in western Europe. Antiquity, 67 (254), 66-73.

Vèlius, G., 2010. Sugrị̌žtantys numirèliai: „netradicinë“laidosena Lietuvos viduramžių senkapiuose. Lietuvos istorijos studijos, 25, 62-73. 
Vèlius, N., sud., 1996. Baltu religijos ir mitologijos šaltiniai, I. Nuo seniausių laiku iki XV amžiaus pabaigos. Vilnius: Mokslo ir enciklopedijų leidybos institutas.

Vèlius, N., sud., 2001. Baltų religijos ir mitologijos šaltiniai, II. XVI amžius. Vilnius: Mokslo ir enciklopedijų leidybos institutas.

Vèlius, N., sud., 2003. Baltu religijos ir mitologijos šaltiniai, III. XVII amžius. Vilnius: Mokslo ir enciklopedijų leidybos institutas.

Vèlius, N., sud., 2005. Baltu religijos ir mitologijos šaltiniai, IV. XVIII amžius. Vilnius: Mokslo ir enciklopedijų leidybos institutas.

Whyte, N., 2003. The after-life of barrows: prehistoric monuments in the Norfolk landscape. Landscape History, 25 (1), 5-16.

Wickholm, A., 2008. Reuse in Finnish Cremation Cemeteries under Level Ground - Examples of Collective Memory. In: Fahlander, F., Oestigaard, T., eds. The Materiality of Death: Bodies, Burials, Beliefs (=BAR International Series, 1768). Oxford: Archaeopress, 89-97.

Williams, H., 1998. Monuments and the past in early Anglo-Saxon England. WA, 30 (1), 90-108.

Williams, H., 2006. Death and Memory in Early Medieval Britain. Cambridge University Press.

Žiogas, J., 1909. Archaiologiški tyrinėjimai Gaidès apylinkèje. Su 21 paveikslèliu (iš „Lietuviu tautos"). Vilnius: M. Kuktos spaustuvè.

Дучыц, Л., 1997. Познесярэдневяковыя курганы Беларусі. Гістарычна-археалагічны зборнік, $12,77-79$.

Зверуго, Я.Г., 1989. Верхнее Понеманье в IXXIII вв. Минск: Навука і тэхніка.

Звяруга, Я.Г., 2005. Беларускае Павілле у жалезным веку і ранннім сярэдневякоўі (=Матэрыялы па археалогіі Беларусі, 10).
Покровскій, Ф.В., 1893. Археологическая карта Виленской губерніи. Вильна: Типографія А.Г. Сыркина.

Седов, В.В., 1982. Восточные славяне в VIХІІІ вв. Москва: Наука.

Спицынъ, А., 1902. Курганы близъ д. Пакальнишекъ, Ковенской губерніи. Извъстія Императорской археологической коммиссіи, 2, 95-98.

Чараўко, В.У., 2010. Матэрыялы да карты пахавальных помнікаў Беларускага Падзвіння XIV-XVIII стагоддзяу. Вестник Полоцкого государственного университета, A, 7, 14-20.

Шукевич, В.А., 1893. Рефератъ В. А. Шукевича объ археологическихъ мъстностяхъ въ Лидскомъ и Трокскомъ уњздахъ. In: Труды Виленскаго отдъленія московскаго предварительнаго комитета по устройству въ Вильнь IX археологическаго съъзда, І. Вильна: Типографія А. Г. Сыркина, 96-100.

Шукевич, В.А., 1897. О раскопкахъ В. А. Шукевича въ Лидскомғ уъздъ Виленской губ. Архив Института истории материальной культуры (Маterialinès kultūros istorijos institutas, Sankt Peterburgas, Rusija). Ф. 1, № 1894/90.

\section{SANTRUMPOS}

AETL - Archeologiniai ir etnografiniai tyrinèjimai Lietuvoje

ATL - Archeologiniai tyrinėjimai Lietuvoje

LA - Lietuvos archeologija

LIIR - Lietuvos istorijos instituto Rankraštynas

WA - World Archaeology 


\title{
BURIAL IN BARROWS IN CHRISTIAN LITHUANIA
}

\author{
Laurynas Kurila
}

\section{Summary}

Burials dug into Iron Age (Roman period - Viking age) barrows can be distinguished in the context of the cemeteries from Lithuania's Late Medieval Early Modern period (late $14^{\text {th }}-18^{\text {th }}$ centuries). The archaeological literature does not pay proper attention to these burials as it does not distinguish them from the totality of the historical period cemeteries or it considers them to be a 'ballast' of Iron Age material. But the collected data about 400 late burials from 26 barrow cemeteries and information about the possible existence of such burials in another 25 barrow cemeteries allow one to state that burials of the dead in old barrows in the Late Medieval and Early Modern periods were not isolated exceptional instances, but rather a fairly widely practiced custom. The large chronological distance from the barrow cemeteries as well as the cultural and religious changes make this phenomenon clearly differ from the interruptions in a cemetery's use and the reuse of previous burial sites frequently witnessed in prehistory. No new barrows were created in the historical period and so the resumption of burials cannot be considered a true rebirth of the barrow tradition.

From one to several tens (Pajuostis, Riklikai, Plaučiškiai, Akmeniai, Paalksniai, and Kybartiškè) of historical period burials have been found in barrow cemeteries. Aside from their unusual location, the bulk of the burials do not differ from the context of the contemporaneous cemeteries. The burials contained individuals of both sexes and of various ages, mostly laid with the head to the $\mathrm{W}$ or close to it, in accordance with Christian custom. 225 individuals were found to have been interred with grave goods characteristic of that period: in earlier burials goods with a more supplemental value (tools, weapons, ornaments), in later ones those of a more personal nature (predominantly clothing elements, small ornaments, and coins).

Historical period burials have been detected in barrows throughout almost all of Lithuanian territory, where burials had been made in barrows at some stage of the Iron Age. Nevertheless the main incidence range of this custom is Samogitia and North Lithuania, i.e. the territory between the River Šventoji and the upper Jüra, the $\mathrm{W}$ and $\mathrm{S}$ sides being naturally defined by the boundaries of the incidence of Roman period barrows in Samogitia and North Lithuania, and running up to Latvia in the N. The earliest such burials should be dated to the late Middle Ages (late $14^{\text {th }}-15^{\text {th }}$ centuries), but burials in old barrows became a massive phenomenon in the $16^{\text {th }}-17^{\text {th }}$ centuries. The internal evolution of the reuse phase of barrow cemeteries is difficult to determine but several examples show that the largest barrows began to be used first. Some barrow cemeteries gradually became completely occupied by rural cemeteries, no distinction being made any longer between the barrow mounds and the intervals between them. Burials in some barrow cemeteries continued up until the $18^{\text {th }}$ $19^{\text {th }}$ century or even the early $20^{\text {th }}$ century.

The return of burial locations to old barrow cemeteries is not unique in a European context. It is interpreted as resistance by the local inhabitants to the spread of Christianity and with the goal of identifying with one's ancestors and a real or supposed past in order to demonstrate and maintain one's social status and claims to occupied territories.

The land ownership system and social order of $15^{\text {th }}-16^{\text {th }}$-century Lithuania forces one to reject the 
model of burials in old barrows as an expression of social or territorial competition. This phenomenon should instead be associated with the Christianisation of Lithuania. On the one hand, because the network of churches in Lithuania was very sparse up until the $16^{\text {th }}$ century and there was a lack of priests and of the spread of Christianity in the local language, the burial of the dead in churchyards and the use of Christian rites had not become entrenched. Several written sources mention burials 'in fields and forests', which can also mean barrow cemeteries. On the other hand, during the earliest stage of Lithuania's Christianisation, there was no great pressure from the Church to change the burial customs, which could have led to a reaction among the population. A greater confrontation between the Church's teachings and the conservatism of the inhabitants appeared in the Reformation and especially the CounterReformation, when the number of churches increased along with attention to the evangelisation of the locals and the observance of Christian rituals. In addition, the exorbitant fees, mentioned in written sources, for Christian burial rites could have had the opposite effect of forcing people to look for cemeteries in even more remote locations. Under these circumstances, some communities probably created new cemeteries while others, where the living space contained old barrow cemeteries and where the memory of the graves of the ancestors had been better retained, returned to them as a symbol of the pagan past. The return to pagan burial sites perhaps also reflects people's confusion and Christianity's weak authority against a background of the diversity of the religion's branches and dogmas, the religious discord, and the frequent conversions.

Several graves dug into barrows, some of which probably date to an even later period, when the dead were unceremoniously dumped in pits, lay on their sides, and were covered with stones, should be attributed to a 'deviant burial' category. These could be the victims of crimes or executions, individuals who had brought the disrespect of the community on themselves, individuals who had been pushed away, or individuals labelled as 'werewolves' or the 'walking dead', i.e. people who evoked fear.

\section{APPENDIX}

Late Medieval - Early Modern period burials in barrows.

\section{LIST OF FIGURES}

Fig. 1. Iron Age barrow cemeteries in which Late Medieval - Early Modern period burials have been found. Red colour - numbers of excavated burials: 1 - Akmeniai, 2 - Berklainiai, 3 - Didžiuliai, 4 - Druskiai, 5 - Kybartiške, 6 - Kretuonai I, 7 Kurganai-Varatniškès, 8 - Lygalaukiai, 9 - MaironiaiSaudininkai, 10 - Maisiejūnai-Surgantiškès, 11 - Muoriškiai, 12 - Noruišiai, 13 - Paalksniai, 14 - Pajuostis, 15 - Pakalniškiai, 16 - Pamarnakis, 17 - Paragaudis, 18 - Pašiliai, 19 - Plaučǐ̌kiai, 20 Raginėnai, 21 - Riklikai, 22 - Semeniškès, 23 Vaineikiai, 24 - Vigodka-Dūkštas-Saksoniškès II, 25 - Vilkonys, 26 - Visdergiai-Papelkiai; green colour - insufficient data: 27 - Adakavas, 28 Gilbonys, 29 - Jagminiškè, 30 - Juostininkai, 31 Kejènai, 32 - Kiemeliai, 33 - Kivyliai, 34 - Kuokšiai, 35 - Lakštingalos, 36 - Lepšiai, 37 - Meldiniai, 38 Mičiūnai, 39 - Miškiniai, 40 - Paduobè-Šaltaliūnè III, 41 - Pajuostis, 42 - Paliečiai, 43 - Pažalvaičiai, 44 Požerè, 45 - Rusiai, 46 - Skrebiškiai, 47 - Skverbai, 48 - Tiltagaliai, 49 - Tolišiai, 50 - Visagina, 51 Visètiškès. Map by L. Kurila.

Fig. 2. Plaučiškiai barrow cemetery, barrow IV, burials 4, 14-16 (Patkauskas 1979b, pav. 54).

Fig. 3. Plaučiškiai barrow cemetery, area between barrows III and VII, burials 5 and 6 (Patkauskas 1979b, pav. 126).

Fig. 4. Burial in Didžiuliai barrow 11 (LIIR, neg. no. 1766). Photo by A. Tautavičius. 
Fig. 5. Orientation of the burials. Graph by L. Kurila.

Fig. 6. Percentage of burials containing grave goods (I) and average number of grave goods (II) in barrow cemeteries: 1 - Akmeniai, 2 - Kybartiškè, 3 Noruišiai, 4 - Paalksniai, 5 - Pajuostis, 6 - Pašiliai, 7 - Plaučiškiai, 8 - Riklikai, 9 - Visdergiai-Papelkiai. Graph by L. Kurila.

Fig. 7. Distribution of grave goods after categories in barrow cemeteries: I - Akmeniai, II - Kybartiškè, III - Paalksniai, IV - Pajuostis, V - Plaučiškiai, VI Riklikai, VII - Visdergiai-Papelkiai. 1 - tools, 2 weapons, 3 - dressing accessories, 4 - ornaments, 5 religious accessories, 6 - other/unidentified items, 7 - coins, 8 - pottery. Graph by L. Kurila.

Fig. 8. Barrow cemeteries (in black) (after Lietuvos 1977; Kultūros 2019; Proligis 2019) and barrow cemeteries in which Late Medieval - Early
Modern period burials have been found (in red). Map by L. Kurila.

Fig. 9. Catholic churches of the Vilnius and Samogitian Dioceses built until the mid-17 ${ }^{\text {th }}$ century (after: Ochmański 1972; Codex 1984; 1989; Błaszczyk 1993; Jučas 2007, p. 52-66) and $10 \mathrm{~km}$ buffer zones around them (in green), and Iron Age barrow cemeteries in which Late Medieval - Early Modern period burials have been found (in red). Map by L. Kurila.

Fig. 10. Evangelical churches and chapels in the territory of the Vilnius and Samogitian Dioceses in the $16^{\text {th }}-$ early $17^{\text {th }}$ centuries (after: Lukšaite 1999 , lent. 3, 4; Vaivada 2004, p. 148-150) and $10 \mathrm{~km}$ buffer zones around them (in green), and Iron Age barrow cemeteries in which Late Medieval - Early Modern period burials have been found (in red). Map by L. Kurila.

Translated by J. A. Bakanauskas 